Carolina Viegas Meohas

\title{
A TUTELA PROVISÓRIA NO NOVO CPC E AS CONTROVÉRSIAS ENVOLVENDO A FAZENDA PÚBLICA
}

Monografia

INSTITUTO DE DIREITO

Curso de Especialização em Direito Processual Civil

Rio de Janeiro Janeiro 2019 
PONTIFÍCIA UNIVERSIDADE CATÓLICA DO RIO DE JANEIRO

INSTITUTO DE DIREITO

Curso de Especialização em Direito Processual Civil

A tutela provisória no Novo CPC e as controvérsias envolvendo a Fazenda Pública

Carolina Viegas Meohas 


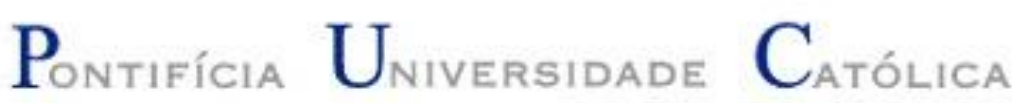

Carolina Viegas Meohas

\section{A tutela provisória no Novo CPC e as controvérsias envolvendo a Fazenda Pública}

Monografia apresentada ao Curso de Especialização em Direito Processual Civil do Instituto de Direito da PUC-Rio como requisito parcial para obtenção do título de Especialista em Direito Processual Civil.

Orientador: Prof. Firly Nascimento Filho

Rio de Janeiro

Janeiro de 2019 


\section{AGRADECIMENTOS}

Agradeço à minha família, pelo amor irrestrito e apoio incondicional. E hoje, dedico esse trabalho a todos aqueles que acreditam e que torcem para que meus sonhos se concretizem, vibrando em cada conquista. 


\section{RESUMO}

MEOHAS, Carolina Viegas. A Tutela Provisória no Novo CPC e as controvérsias envolvendo a Fazenda Pública. Curso de Especialização em Direito Processual Civil, Pontifícia Universidade Católica do Rio de Janeiro, Rio de Janeiro, 2019.

O artigo 5ำ, XXXV da CRFB/88 preconiza que a lei não excluirá da apreciação do Poder Judiciário lesão ou ameaça a direito, assegurando à todos amplo acesso à justiça. Desse dispositivo podemos extrair o direito de ação, ou seja, direito a uma prestação jurisdicional. No entanto, não podemos interpretar esse mandamento constitucional de forma isolada, como sendo mero direito de ingresso do jurisdicionado ao poder judiciário. Mais do que isso, essa garantia constitucional significa um direito a tutela jurisdicional justa, efetiva, adequada e tempestiva. Os provimentos provisórios se incluem dentre as garantias processuais previstas pelo ordenamento jurídico para concretizar o direito de ação. O CPC/15, a fim garantir o acesso à justiça, dando maior efetividade ao processo, prevê a tutela provisória, que apesar de não resolver definitivamente a solução posta em juízo, posto que fundada em cognição sumária, tem por escopo equilibrar o fator tempo do processo, seja o protegendo do risco de ineficácia, através do instituto da tutela cautelar, seja adiantando os efeitos práticos de um futuro provimento jurisdicional, através da técnica da antecipação de tutela. Dessa forma, tais mecanismos são hábeis à garantia da efetividade da Justiça, uma vez que o tempo do processo pode gerar efeitos nocivos ao direito discutido por meio deste e, o CPC/15 atento a isso, traz grandes e importantes inovações a esse instituto, quando comparado à sistemática preconizada pelo $\mathrm{CPC} / 73$. Nesse contexto, o presente trabalho tem por finalidade abordar as implicações da entrada em vigor do novo Código de Processo Civil em relação à tutela provisória, demonstrando os principais aspectos acerca da tutela de urgência e da tutela de evidência que vão além da clássica distinção entre as técnicas da tutela cautelar e antecipatória. Abordaremos também as implicações da entrada em vigor do novo Código de Processo Civil em relação à tutela provisória concedida em desfavor da Fazenda Pública, tendo em vista que esse instituto sofre limitações nesses casos, uma vez que nos litígios envolvendo as pessoas jurídicas de direito público, além da incidência do princípio da supremacia do interesse público e da sua indisponibilidade, a legislação ordinária preconiza outras prerrogativas dispensadas ao Poder Público que acabam por gerar restrições à concessão de provimentos liminares. Por meio de pesquisa junto à doutrina pátria e à jurisprudência, o presente estudo analisará a constitucionalidade /ou inconstitucionalidade dessas restrições previstas em lei, bem como as principais modificações concernentes às tutelas provisórias e as controvérsias decorrentes da aplicação prática dessa técnica processual em face do Poder Público. Outrossim, far-se-á uma análise da técnica da estabilização da tutela antecipada antecedente em caráter geral e com enfoque na Fazenda Pública, apresentando as inúmeras controvérsias acerca da temática, apontando eventuais óbices à estabilização em face do Poder Público, como por exemplo, a incidência do princípio da indisponibilidade do interesse público, o reconhecimento doutrinário de um microssistema formado entre a estabilização e a ação monitória e a exigência legal da remessa necessária como condição para a estabilização.

Palavras-chave: Tutela provisória. Tutela de urgência. Tutela de evidência. Novo Código de Processo Civil. Fazenda Pública 


\section{SUMÁRIO}

Introdução

PARTE I - Tutela Provisória

1. A Constitucionalização do Processo.................................................12

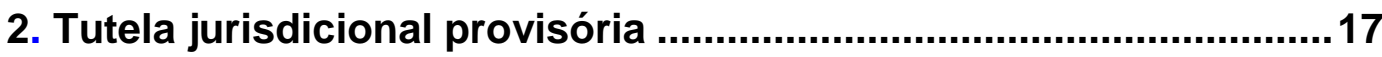

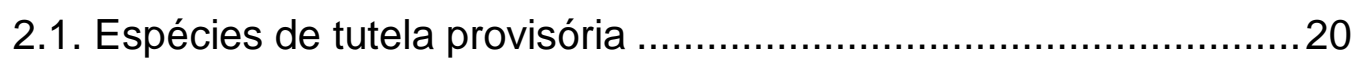

3. A tutela provisória de urgência: Tutela Cautelar e antecipação de

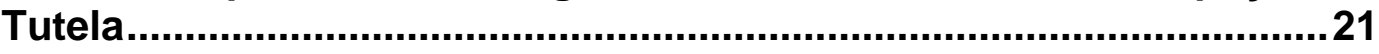

3.1. Tutela jurisdicional de urgência à luz do CPC $/ 73 \ldots \ldots \ldots \ldots \ldots \ldots \ldots . . . . . .21$

3.1.1. Considerações gerais acerca da tutela antecipada à luz do

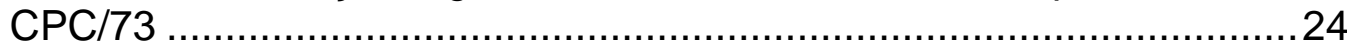

4. Distinção entre tutela cautelar e tutela antecipada .........................28

5. Classificação das tutelas de urgência: tutela cautelar e tutela antecipada como espécies do gênero da tutela de urgência ..............30

6._Características das tutelas provisórias...........................................32

6.1. Características comuns à tutela cautelar e a antecipação de tutela 32

6.2. Características específicas da tutela cautelar de urgência .............38

6.3. Características específicas da tutela antecipada de urgência .......43

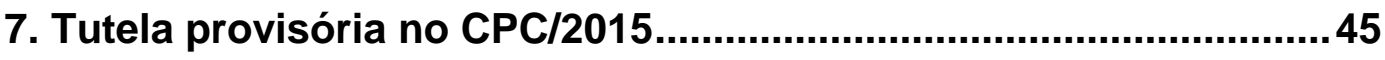

7.1. Conceito de tutela provisória adotado pelo $\mathrm{CPC} / 15 \ldots \ldots \ldots \ldots \ldots \ldots \ldots . . . .45$

7.2. As disposições gerais do $\mathrm{CPC} / 15$ a respeito da tutela de urgência:

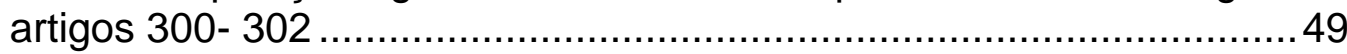

8. A tutela antecipada requerida em caráter antecedente e sua

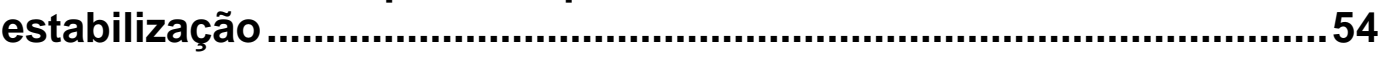

8.1. Estabilização da tutela antecipada em caráter antecedente ..........57

8.2. Limites à estabilização da tutela antecipada antecedente ..............65

9. A tutela cautelar requerida em caráter antecedente no novo CPC:

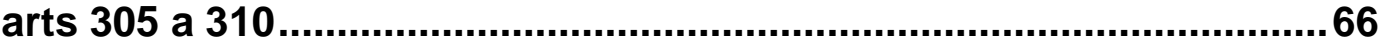

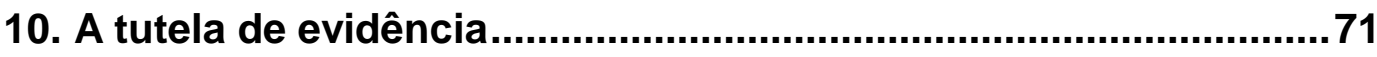

10.1. A tutela de evidência no código de processo civil de 1973 ...........71

10.2. A tutela de evidência no Código de Processo Civil de 2015 .........72 
PARTE II - Tutela Provisória em face da Fazenda Pública

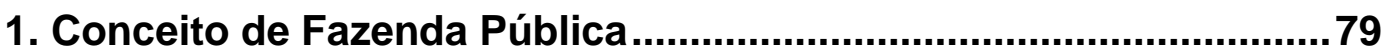

2. Prerrogativas Processuais da Fazenda Pública ..............................82

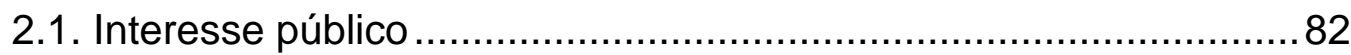

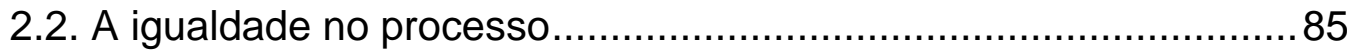

3. Tutela antecipada em face da Fazenda Pública à luz do $\mathrm{CPC} / 73 \ldots 89$

4. Tutela de urgência contra a Fazenda Pública ..................................91

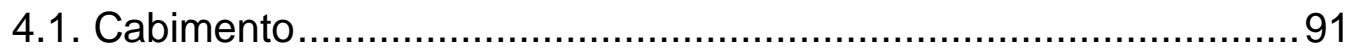

4.2. Vedações legais à tutela de urgência em face da Fazenda Pública 91

5. Restrições à concessão da tutela provisória em face do Poder

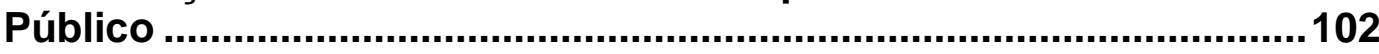

5.1. Divergência doutrinária acerca da constitucionalidade das regras que vedam a concessão de provimento de urgência em face de entidades integrantes da Administração Pública ................................. 102

6. A estabilização da tutela antecipada antecedente e a Fazenda

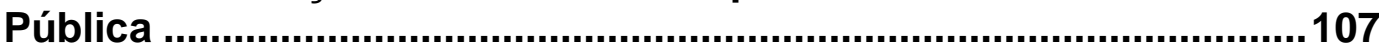

6.1. Peculiaridades que envolvem a atuação da Fazenda Pública em

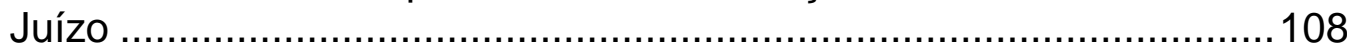

6.2. Os óbices levantados pela doutrina à estabilização da tutela antecipada em face da Fazenda Pública ........................................... 109

7. Tutela de evidência contra a Fazenda Pública .............................114

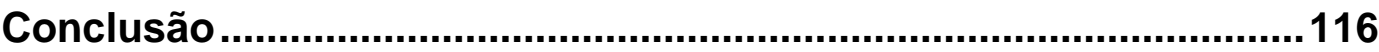

Referências Bibliográficas .........................................................120 


\section{SIGLAS E ABREVIATURAS}

§- Parágrafo

Art. - Artigo.

ADC - Ação Declaratória de Constitucionalidade

ADI - Ação Direta de Inconstitucionalidade

CF/88 - Constituição Federal de 1988

CPC/1973 - Código de Processo Civil de 1973

CPC/2015 - Código de Processo Civil de 2015

Ed. - Edição

Min. - Ministro (a)

NCPC - Novo Código de Processo Civil

no - Número

p. - Página

Rel. - Relator (a)

RE - Recurso Extraordinário

REsp - Recurso Especial

STF - Supremo Tribunal Federal

STJ - Superior Tribunal de Justiça

t. - Tomo

Vol. ou v. - Volume 


\section{Introdução}

O direito processual, conforme consagrado cientificamente, deve adequar-se às peculiaridades de determinado direito material. Por isso, podemos falar em tutelas diferenciadas, devendo haver um processo apto a garantir aquele direito específico, mediante regras processuais que lhe sejam apropriadas.

No tocante à Fazenda Pública, deverá haver sua submissão a princípios e regras de direito público, sendo certo que nesse caso vigorará um regime jurídico diferenciado, onde incidirão princípios específicos, tais como, o princípio da legalidade, a presunção de legitimidade dos atos administrativos, a autoexecutoriedade dos atos administrativos, a supremacia do interesse público, bem como a indisponibilidade do interesse público.

O legislador infraconstitucional atento a esse regime jurídico de direito público dispensou tratamento diferenciado às pessoas jurídicas de direito público, conferindo-lhes prerrogativas materiais e processuais, a fim de possibilitar que a Advocacia Pública consiga exercer plenamente o direito de defesa dos entes públicos, evitando, por conseguinte, condenações injustificáveis.

$\mathrm{Na}$ mesma direção, com o escopo de tutelar o interesse público, ciente de que os recursos públicos são finitos e de que a concessão de providências liminares em desfavor do Poder Público muitas vezes têm efeitos irreversíveis, o legislador passou a restringir, no final da década de 1950, as hipóteses de cabimento das decisões provisórias no âmbito do mandado de segurança, exigindo em alguns casos o trânsito em julgado para que os provimentos proferidos em face dos entes públicos produzam efeitos.

A partir dos anos 1990, há um aumento gradativo das vedações legais preconizadas para as demandas envolvendo o Poder Público, as quais foram estendidas inicialmente às medidas cautelares e, logo após, à técnica da antecipação de tutela.

Nesse contexto, surgem inúmeras discussões acerca da constitucionalidade dessas vedações legais, entendendo alguns que tais restrições seriam 
inconstitucionais, por atentarem contra a garantia da inafastabilidade da tutela jurisdicional.

Aliado a isso, o direito processual civil acaba por sofrer significativas modificações com o advento do Novo Código de Processo Civil.

O presente trabalho tem por escopo analisar primeiramente o modelo constitucional de processo, que inspirou o "nascimento" do Novo Código de Processo Civil, promulgado pela Lei 13.105 de 16.03.2015. ${ }^{1}$

Pela leitura da exposição de motivos, verifica-se que o CPC/15 passa a exigir do operador do direito uma nova percepção acerca do direito processual brasileiro. Dentre os principais objetivos que orientaram a elaboração do anteprojeto do $\mathrm{CPC} / 15^{2}$ pela Comissão de Juristas, presidida pelo Ministro Luiz Fux estava : (i) estabelecer harmonia com a Constituição; (ii) criar condições para decisões com maior aderência à realidade social; (iii) viabilizar uma simplificação dos procedimentos e redução de complexidades; (iv) dar maior rendimento a cada processo; e (v) imprimir maior organicidade e coesão ao sistema.

Como se percebe, o legislador preocupou-se em assentar que os institutos do direito processual civil devem ser analisados e interpretados visando realizar os direitos e garantias fundamentais, promovendo o Estado Democrático de Direito instituído pela Constituição.

O presente trabalho dividir-se-á em duas partes. A primeira parte se destinará ao exame da tutela provisória, gênero, do qual a tutela de urgência e de evidência são espécies, abordando as diversas modificações trazidas pelo Novo Código de Processo Civil a esse instituto. Demonstraremos ao longo de nosso estudo, aspectos que vão além da clássica distinção entre as técnicas cautelas e antecipatórias, uma vez que o novo Código apesar de não ter adotado um regime jurídico único, porquanto traz procedimentos distintos para a tutela antecipada e tutela cautelar antecedentes, as aproximou bastante, principalmente se comparado ao Código de Processo Civil de $1973^{3}$. Outrossim, abordaremos a tutela de evidência, que veio a ser reforçada pela entrada em vigor do novo Código de Processo Civil.

1 BRASIL. Lei n. $\mathbf{1 3 . 1 0 5}$ de 16 de março de 2015. Planalto. Disponível em: < https://www.planalto.gov.br/ccivil_03/_ato2015-2018/2015/lei/l13105.htm>. Acesso em: 5 dez. 2018, passim.

${ }^{2}$ Idem.

${ }^{3}$ BRASIL. Lei $\mathbf{n}^{0} \mathbf{5 . 8 6 9}$, de 11 de janeiro de 1973. Código de processo civil. Disponível em: <http://www.planalto.gov.br/ccivil_03/LEIS/L5869.htm>. Acesso em: 10 nov. 2018, passim. 
Faremos um estudo voltado a uma interpretação sistemática e teleológica dos princípios e normas relativos à modalidade da tutela provisória. Demonstraremos que em tempos atuais, o procedimento comum tem-se revelado insuficiente para tutelar de forma célere e eficaz os direitos, porquanto permanece alheio aos males causados pelo tempo dos processos judiciais, males esses que a cada dia tornam-se mais evidentes, frustrando o ideal de um processo efetivo. Em meio a esse panorama advém o novo CPC, que traz uma clara evolução ao traçar uma disciplina comum à tutela de urgência, seja ela cautelar ou antecipada, ao lado da tutela de evidência, ambas sob o "rótulo" tutela provisória.

A segunda parte , por seu turno, destinar-se-á ao estudo da Fazenda Pública, iniciando pela delimitação de seu conceito, para logo após, explicitar as prerrogativas que são próprias do regime jurídico das pessoas jurídicas de direito público.

Em seguida, serão abordadas as vedações legais à concessão de medidas liminares em desfavor do Poder Público, em relação às quais, em um segundo momento, buscar-se-á apresentar as principais divergências doutrinárias acerca dessas restrições legais. Por fim, apresentar-se-á as principais inovações em matéria de tutela provisória, como por exemplo, a estabilização da tutela antecipada antecedente, de modo a confrontá-las com o regime inerente aos entes públicos, buscando identificar suas principais controvérsias. 


\section{PARTE I - Tutela provisória}

\section{1}

\section{A Constitucionalização do Processo}

Durante muito tempo, o Direito como um todo, nos interessando citar o direito constitucional e processual civil sofreu influência do positivismo na interpretação e aplicação das normas jurídicas. Todavia, nos dias atuais, sobressai a ideia do pós-positivismo, que surge com o escopo de impedir o ressurgimento do direito natural, bem como o de suprimir as falhas do positivismo jurídico, visando analisar a aplicabilidade das normas jurídicas com base nos valores do ordenamento, não sendo consideradas legítimas apenas pela regularidade de seu modo de produção.

Com o pós-positivismo, as normas constitucionais passam a ter papel fundamental na atuação de todo o ordenamento jurídico. Pode-se dizer, nesse sentido, que a lei perde o seu posto de supremacia e passa a estar subordinada à Constituição.

Nesse contexto pós-positivista e de busca da concretização das normas, surge o neoconstitucionalismo, que a partir de diversos fenômenos faz emergir a constitucionalização do processo e do Direito como um todo.

Assim, o estudo do processo civil passa a ter como ponto de partida e de chegada a CRFB/88 e não o Código de Processo Civil. Dessa forma, as normas processuais devem ser interpretadas de acordo com os mandamentos constitucionais.

No entanto, conforme bem esclarece João Batista Lopes, apoiado em Dworkin, Alexy, Canaris e Tercio Sampaio Ferraz, não podemos deixar de nos atentar para os riscos de supervalorização dos princípios constitucionais do processo, lembrando que estes, posto que sejam normas fundantes, não são absolutos, devendo ser avaliados à luz do princípio da proporcionalidade. 


\section{Afirma João Batista Lopes,}

trata-se de um método de estudo que tem como ponto de partida e de chegada a própria Constituição Federal, mas não se pode ignorar à evidência, os princípios e regras do direito processual civil. Não se trata, pois, de esvaziar o direito processual civil, mas de estudá-lo à luz da Constituição para fazer atuar concretamente os valores da ordem jurídica. ${ }^{4}$

Diante desse fenômeno, Paulo Ricardo Scheir no mesmo sentido, propõe que normas infraconstitucionais sejam interpretadas a partir dos valores consagrados em nossa Constituição Federal. Para tanto, utilizou-se da expressão "filtragem constitucional", uma vez que denota a ideia de um processo em que toda a ordem jurídica, sob a perspectiva formal e material, e assim os seus procedimentos e valores, devem passar necessariamente pelo filtro axiológico da Constituição Federal, impondo a cada momento de aplicação do Direito uma releitura e atualização de suas normas. ${ }^{5}$

Trata-se, portanto, de uma tábua axiológica a partir da qual devem ser analisadas as previsões legais.

A Constituição, por se tratar de norma jurídica fundamental, é formada por um sistema de princípios e regras jurídicas que produzem efeitos reais. Norma jurídica é um conceito amplo, complexo e de difícil conceituação. Apesar disso, podemos afirmar que é gênero, do qual princípios e regras são espécies. Ainda que tal distinção gere polêmica, costuma-se dizer que os princípios têm como características a generalidade e abstração, ao passo que as regras, caracterizam-se pela determinação e concreção.

Há uma diferença qualitativa entre princípios e regras. Nesse sentido, esclarece Ronald Dworkin, afirmando que os princípios têm uma dimensão de peso que estão ausentes nas regras.

Os princípios possuem uma dimensão que as regras não têm - a dimensão de peso ou importância. Quando os princípios se entrecruzam, aquele que vai resolver o conflito tem de levar em conta a força relativa de cada um (....). Não obstante, essa dimensão é uma parte integrante do conceito de um princípio, de modo que faz

\footnotetext{
${ }^{4}$ LOPES, João Batista. Efetividade da tutela jurisdicional à luz da constitucionalização do processo civil. Revista de Processo. Vol. 116. p. 31-32 São Paulo: ed. RT, jul-ago 2004.

${ }^{5}$ SHIER, Paulo Ricardo. Filtragem constitucional. Construindo uma nova dogmática jurídica. Porto Alegre: Sergio Antonio Fabris,1999. p. 104.
} 
sentido perguntar que peso ele tem ou quão importante ele é. ${ }^{6}$

Ainda, segundo Alexy, princípios diante de sua generalidade, devem ser entendidos como normas de otimização, compatíveis com os vários graus de concretização, conforme os condicionamentos fáticos e jurídicos, enquanto as regras, por serem normas que prescrevem imperativamente uma exigência, simplesmente são ou não cumpridas. ${ }^{7}$

Dessa forma, havendo conflito entre princípios, pondera-se os princípios conflitantes, de forma a prestigiar aquele que proteja o valor mais relevante para a solução do caso concreto, sem que se tenha por revogado o princípio subjugado. Ao revés, o conflito entre regras obedece a lógica do "tudo ou nada", sendo inconcebível a validade de regras contraditórias. Assim, uma será aplicada, enquanto a outra será excluída do sistema. Portanto, podemos perceber que apesar de ambos serem espécies de normas jurídicas, apresentam importantes distinções.

Não podemos deixar de mencionar a lição de Celso Antônio Bandeira de Mello acerca dos princípios:

Princípio é por definição, mandamento nuclear do sistema, verdadeiro alicerce dele, disposição fundamental que irradia sobre diferentes normas compondo-lhe o espírito e servindo de critério para a sua exata compreensão e inteligência, exatamente por definir a lógica e a racionalidade do sistema normativo, no que lhe confere a tônica e lhe dá sentido harmônico. É o conhecimento dos princípios que preside a intelecção das diferentes partes componentes do unitário que há por nome sistema jurídico positivo. Violar um princípio é muito mais grave que transgredir uma norma qualquer. A desatenção ao princípio implica ofensa não apenas a um específico mandamento obrigatório, mas a todo o sistema de comandos. É a mais grave forma de ilegalidade ou inconstitucionalidade, conforme o escalão do princípio atingido, porque representa insurgência contra todo o sistema, subversão dos seus valores fundamentais, contumélia irremissível a seu arcabouço lógico e corrosão de sua estrutura mestra. Isto porque, ao ofendê-lo, abate-se as vigas que o sustêm e alui-se toda a estrutura nelas esforçada. ${ }^{8}$

No tocante ao direito processual, podemos encontrar um extenso rol de direitos e garantias fundamentais elencados no artigo $5^{\circ}$ da CRFB $/ 88^{9}$, dentre outras normas processuais espraiadas em outros dispositivos constitucionais.

${ }^{6}$ DWORKIN, Ronald. Levando o direito a sério. Trad. Nelson Boeira. São Paulo: Martins Fontes, 2002. p. 42-43.

7 ALEXY. Robert. Derecho y razón prática. 2. ed. Trad Manuel Atienza. México: BEFDP, 1998. p. 12.

${ }^{8}$ MELLO, Celso Antônio Bandeira de. Curso de direito administrativo. 5. ed. São Paulo: [s.n.], 1994. p. 450-451.

${ }^{9}$ BRASIL. Constituição da República Federativa do Brasil de 1988. Art. $5^{\circ}$. Disponível em: < www.senado.leg.br/atividade/const/con1988/con1988_15.12.2016/art_5_.asp>. Acesso em: 10 nov. 2018. 
Conforme ensina Candido Rangel Dinamarco, "a Constituição realiza uma tutela do processo por meio de princípios e garantias aplicáveis a este. Simultaneamente, de outro lado, o processo também tutela a Constituição, já que cumpre papel na efetividade das normas constitucionais."

Como é sabido, os direitos fundamentais se caracterizam como sendo direitos subjetivos dos indivíduos, bem como elementos objetivos basilares do Estado. Ingo Sarlet, cuidando da eficácia objetiva dos direitos fundamentais, afirma que eles não se limitam à função precípua de serem direitos subjetivos de defesa do indivíduo contra atos do Poder Público, mas que, além disso, constituem decisões valorativas de natureza jurídico-objetiva da Constituição, com eficácia em todo o ordenamento jurídico e que fornecem diretrizes para os órgãos legislativos, judiciários e executivos. ${ }^{10}$

Dessa forma, o direito processual civil deve ter por escopo uma atuação visando atribuir a maior efetividade aos direitos fundamentais. Os institutos de direito processual devem ser analisados e interpretados buscando realizar esses direitos e valores, a fim de promover o Estado Democrático de Direito pela Constituição.

A tutela provisória, objeto específico de nosso estudo, também passou a ser vista como uma garantia constitucional, sendo certo que qualquer disposição normativa que vede ou dificulte tal tutela, deve ser tida como inconstitucional. Assim, fica evidente a importância desse fenômeno da constitucionalização do processo civil na abordagem que deve ser dada à tutela jurisdicional provisória e a todo o seu instrumental preconizado na legislação ordinária.

Nesse sentido, José dos Santos Bedaque adverte que "o complexo de normas constitucionais, direcionadas para a garantia do sistema processual, constitui o primeiro passo para conferir efetividade possível à tutela que emerge do processo." $" 11$

Assim, não podemos deixar de mencionar alguns dos mais relevantes princípios processuais expressos ou implícitos em nossa norma fundamental, imprescindíveis para o estudo da tutela provisória, tais como o devido processo legal, a inafastabilidade do controle jurisdicional, o contraditório, a ampla defesa,

\footnotetext{
${ }^{10}$ SARLET, Ingo Wolfgang. A eficácia dos direitos fundamentais. 3. ed. Porto Alegra: Livraria do advogado, 2003. p. 147.

${ }^{11}$ BEDAQUE, José Roberto dos Santos. Tutela Cautelar e tutela antecipada: tutelas sumárias e de urgência (tentativa de sistematização). 3. ed. São Paulo: Malheiros, 2003.
} 
a fundamentação das decisões judiciais, a isonomia, razoabilidade, proporcionalidade, efetividade e a razoável duração do processo.

Todavia, podemos vislumbrar para a solução da tutela provisória, o conflito das seguintes garantias constitucionais: de um lado, o devido processo legal, o contraditório e ampla defesa e de outro, a inafastabilidade do controle jurisdicional, o acesso a uma tutela jurisdicional efetiva, a duração razoável do processo e a isonomia. $\mathrm{O}$ equilíbrio, nesses casos, deverá ser alcançado por meio da aplicação do princípio da proporcionalidade, que tem cunho constitucional e infraconstitucional.

A essa atividade judicial de sanar ou prevenir lesões ou ameaças a direitos até uma solução definitiva, imprescindível para uma tutela jurisdicional em consonância com a Constituição, Humberto Theodoro Jr dá o nome de "litisregulação".

Adverte o processualista:

É nesse quadro principiológico conflituoso que se impõe a tutela jurisdicional de urgência, como remédio provisório e necessário. Assim, no hiato inevitável interposto entre o ajuizamento da causa e o provimento final de mérito, os problemas que põem em risco a efetividade do processo devem ser equacionados pelo juiz, afastando-se de imediato tudo aquilo que possa tornar inútil ou insatisfatória a prestação definitiva que se espera alcançar ao fim do processo. A essa atividade complementar dá-se o nome de regulação provisória, listisregulação ou ainda tutela de urgência. A litisregulação nessa ordem de ideias, compreende atividade judicial da que o devido processo legal atingirá, na solução do litígio, mas é também atividade jurisdicional, porque tende a sanar ou prevenir lesões ou ameaças a direito que não podem ser subtraídas ao Poder Judiciário, segundo a garantia da efetividade da tutela jurisdicional. ${ }^{12}$

12 THEODORO JR., Humberto. Tutela jurisdicional de urgência- Medidas cautelares e antecipatórias. 2. ed. Rio de Janeiro: América Jurídica, 2001. p. 12. 


\section{2 \\ Tutela jurisdicional provisória}

A sociedade atual é marcada pela rapidez das informações, e pelas mais diversas relações sociais, econômicas e jurídicas. Por essa razão, uma prestação jurisdicional tardia de nada adianta àquele que pleiteia a tutela jurisdicional. A relação entre tempestividade e efetividade é evidente. O processo tem por escopo alcançar o equilíbrio entre segurança e celeridade, numa tentativa constante de encontrar a melhor solução possível para o caso concreto.

Disso resulta, uma busca permanente no processo, de uma decisão que seja a mais próxima da certeza no menor tempo possível. Segundo Fernando Gajardoni:

é tempestiva a tutela jurisdicional quando os prazos legalmente prefixados para o trâmite e instrução do processo, concebidos em vista das circunstâncias de fato da demanda, do direito a ser protegido, do contraditório e da ampla defesa, são cumpridos pelas partes e pelo órgão jurisdicional. ${ }^{13}$

Sendo assim, o processo civil não só precisa ser apto a efetivar todos os direitos assegurados, mas também, e principalmente, fazê-lo de uma forma mais célere e efetiva, com o menor dispêndio de tempo e de recurso possível, e uma das técnicas disponíveis em nosso ordenamento que visa tentar solucionar ou ao menos minimizar tal problema, é a tutela provisória, que embora não resolva definitivamente a solução posta em juízo, tem por escopo equilibrar o fator tempo do processo, seja protegendo o processo do risco de ineficácia, através do instituto da tutela cautelar, seja adiantando os efeitos práticos de um futuro provimento jurisdicional, através da técnica da antecipação de tutela.

Humberto Theodoro $\mathrm{Jr}$ adverte acerca da diferenciação entre tutela jurisdicional e prestação jurisdicional. Enquanto a primeira efetivamente protege e

\footnotetext{
${ }^{13}$ GAJARDONI, Fernando da Fonseca. Flexibilização procedimental: um novo enfoque para o estudo do procedimento em matéria processual, de acordo com as recentes reformas do CPC. São Paulo: Atlas, 2008. In. Reflexos do tempo no direito processual civil, Revista de Processo, v. 153, nov. 2007. p. 115.
} 
satisfaz o direito, a segunda, por sua vez, representaria o serviço judiciário que se instrumentaliza por meio do processo para a solução da lide.

Nas palavras do jurista;

Urge não confundir tutela com prestação jurisdicional, uma vez que se tem como abstrato o direito de ação, a garantia de acesso do litigante à justiça lhe assegura um provimento jurisdicional, capaz de proporcionar a definitiva solução do litígio, mesmo quando o autor não detenha de fato o direito que afirma violado ou ameaçado pelo réu. Na satisfação do direito à composição do litígio (definição da atuação da vontade concreta da lei diante do conflito instalado entre as partes) consiste a prestação jurisdicional. Mas, além dessa pacificação do litígio, a defesa do direito subjetivo ameaçado ou a reparação da lesão já consumada sobre o direito da parte também incumbe à função jurisdicional realizar, porque a justiça privada não é mais tolerada, salvo excepcionalíssimas exceções, pelo sistema objetivo do direito moderno. Assim, quando o provimento judicial reconhece e resguarda in concreto o direito subjetivo da parte, vai além da simples prestação jurisdicional e, pois, realiza a tutela jurisdicional. Todo litigante que ingressa em juízo, observando os pressupostos processuais e as condições da ação, tem direito à prestação jurisdicional (sentença de mérito ou prática de certo ato executivo), mas nem todo litigante faz jus à tutela jurisdicional. ${ }^{14}$

A doutrina processualista afirma que o processo civil preconiza três formas de tutela, quais sejam a de conhecimento, a cautelar e a executiva, que podem ser classificadas de diversas formas. Além da classificação baseada no provimento judicial, também merece registro o critério de classificação com fulcro na técnica processual adotada. Nessa hipótese, doutrina diferencia a tutela comum da tutela diferenciada. Convém ressaltar, no entanto, que não há consenso doutrinário acerca do termo tutela diferenciado.

A tutela comum é aquela que não apresenta especificidades, adotada para a generalidade dos casos. Já a tutela diferenciada está relacionada à efetividade do processo, na medida em que deve ser assegurada à parte a espécie de tutela mais adequada e efetiva à proteção do direito pleiteado.

Segundo José Roberto dos Santos Bedaque:

A Tutela jurisdicional diferenciada pode ser entendida de duas maneiras diversas; a existência de procedimentos específicos de cognição plena e exauriente, cada qual elaborado em função de especificidades da relação material; ou a regulamentação de tutelas sumárias, típicas, precedidas de cognição não exauriente, visando evitar que o tempo possa comprometer o resultado do processo. ${ }^{15}$

\footnotetext{
14 TEODORO JR, H., op. cit., p. 2.

${ }^{15}$ BEDAQUE, j. R. dos S., op. cit., p. 26
} 
Assim, diante das diferentes acepções do termo tutela jurisdicional diferenciada, aquela que nos interessa para análise mais detida é a correspondente às tutelas sumárias, precedidas de cognição não exauriente, quais sejam, a tutela provisória de urgência e de evidência.

A tutela provisória tem como uma de suas características, conforme mencionamos, a sumariedade da cognição. Trata-se de um juízo de plausibilidade/ probabilidade e não de certeza, ficando sujeita à confirmação por um ato ulterior, fruto de uma cognição exauriente.

Luiz Guilherme Marinoni afirma à luz do $\mathrm{CPC} / 73$, que a técnica da cognição sumária tem por escopo: "assegurar a viabilidade da realização de um direito (tutela cautelar); realizar, em vista de uma situação de perigo, antecipadamente um direito (tutela antecipatória fundada no 273, I do CPC); realizar, em razão das peculiaridades de um determinado direito e/ou em vista da demora de um procedimento ordinário, antecipadamente um direito (liminares de determinados procedimentos especiais); realizar, quando o direito do autor surge como evidente e a defesa é exercida de modo abusivo, antecipadamente um direito (tutela antecipatória fundada no 273, II do CPC)."16 .Tal raciocínio aplica-se também ao CPC/15.

Por sua vez, Ministro Luiz Fux não associa necessariamente a situação de urgência à sumariedade de cognição, afirma que:

A atividade sumária não tem correlação com o grau de convencimento do juízo acerca do direito, revelando-se em expediente autorizativo de um julgamento com base em 'lógica razoável' em função da necessidade de se prover de imediato. Mas não obsta a que se tenha que prover de imediato com base em direito evidente. Destarte, se o direito não for evidente, mas se tornar premente a tutela, autoriza-se a sumarização da cognição com o provimento imediato calcado em juízo de mera probabilidade, como sói ocorrer com a tutela cautelar. O mesmo fenômeno ocorre em sede de "tutela de segurança". Com a peculiaridade de que o provimento pode retratar no plano da razoabilidade prática uma solução secundum eventum litis, irreversível, cujo regime há de ser igual ao das decisões definitivas expedidas após cognição exauriente. Esta, em nosso entender, vai depender do direito material jurídico- probatório levado ao juízo. O direito evidente, fartamente comprovado, admite uma cognição rápida, sumária e exauriente. Há outros casos em que, mercê da urgência, o direito não parece evidente ao juízo, mas a lei autoriza a prover com base apenas na aparência, valorizando a celeridade em detrimento da segurança do julgado. Por isso que não nos parecem indissoluvelmente ligados os conceitos de

16 MARINONI, Luiz Guilherme. Antecipação de Tutela. 10. ed. São Paulo: Revista dos Tribunais, 2008. p. 32-33. 
cognição sumária e juízo de probabilidade, podendo haver cognição sumária e direito evidente. ${ }^{17}$

Apesar de se tratar de temática polêmica, concordamos com José dos Santos Bedaque. O jurista reconhece que todas as tutelas sumárias são precedidas de cognição não exauriente, cuja função é impedir que o tempo de duração do processo venha a comprometer sua efetividade. ${ }^{18}$

\section{1}

\section{Espécies de tutela provisória}

As tutelas diferenciadas provisórias abrangem a tutela de urgência e de evidência. As tutelas de urgência, por sua vez, se dividem em tutela de urgência satisfativa e tutela de urgência cautelar.

17 FUX, Luiz (Ministro). Tutela jurisdicional: finalidade e espécie. Informativo jurídico da Biblioteca Ministro Saraiva. vol. 14. N.2 p. 153-168. Brasília: STJ, jl- dez 2002.

${ }^{18}$ BEDAQUE, J. R. dos S., op. cit., p. 117. 


\section{A tutela provisória de urgência: Tutela Cautelar e Antecipação de Tutela}

\section{1}

\section{Tutela jurisdicional de urgência à luz do CPC /73}

No $\mathrm{CPC} / 73$, cada espécie de tutela jurisdicional era prestada num tipo próprio de processo. O Livro I do CPC/73 previa o processo de conhecimento, o Livro II disciplinava o processo de execução e o Livro III preconizava a tutela cautelar, tratando-a como um processo autônomo.

Por isso, podemos afirmar que tutela cautelar foi a primeira espécie de tutela de urgência a ser tratada de forma genérica e abrangente pelo legislador pátrio, uma vez que contou com livro próprio e regramento detalhado ao longo de 94 artigos e respectivos parágrafos (arts 798-889).

A exposição de motivos do CPC/73 estabelecia que na tradição de nosso direito processual, era a função cautelar distribuída por três espécies de processos, designados por preparatórios, preventivos e incidentes. O projeto, reconhecendolhe caráter autônomo, reuniu os vários procedimentos preparatórios, preventivos e incidentes sob uma fórmula geral, não tendo encontrado melhor vocábulo que o adjetivo cautelar para designar a função que exercem. A expressão processo cautelar tem a virtude de abranger todas as medidas preventivas, conservatórias e incidentes que o projeto ordena no Livro III, e, pelo vigor e amplitude de seu significado, traduz melhor que qualquer outra tutela legal.

Pela leitura da exposição de motivos, Alfredo Buzaid assevera que o Livro III do CPC/73 mereceu uma função de destaque no nosso sistema jurídico, surgindo assim, uma nova face da jurisdição, um tertium genus do processo, que contém a um só tempo as funções do processo de conhecimento e de execução.

Teori Albnino Zavascki, seguindo lição de Calamandrei, faz uma crítica a esta classificação tradicional tripartite, na medida em que a tutela cautelar também é prestada mediante atividades cognitivas e executivas. Para ele, "a tutela cautelar constitui espécie de tutela provisória, contraposta à tutela definitiva, sendo 
impróprio, classifica-la com base na atividade jurisdicional, que mesmo na seara cautelar, continuaria sendo de cognição e execução."19

A doutrina tradicional sempre estabeleceu uma distinção entre processo, ação, medida e liminar cautelar. Com efeito, o processo cautelar é o instrumento posto à disposição do jurisdicionado para exercitar o seu direito de ação. Já a ação cautelar pode ser definida como sendo o direito subjetivo à tutela jurisdicional cautelar, consistente no direito de assegurar a utilidade do resultado do processo principal. Por sua vez, a medida cautelar é o provimento jurisdicional, liminar, ou final, que concede a pretensão assecuratória pleiteada pela parte e, por fim, a liminar diz respeito à concessão da medida cautelar no início do procedimento.

Tal entendimento doutrinário não é isento à críticas. Cassio Scarpinella Bueno, em divergência com a doutrina tradicional, adverte que tais expressões serviriam tão somente para explicar a própria razão do Livro III do Código de Processo Civil de 1973.

Segundo ele:

há simplesmente um processo, sem qualquer qualificativo, em que se desenvolvem determinadas atividades jurisdicionais para o atendimento de determinados fins. De igual forma, há uma única ação, invariável, porque consiste no direito subjetivo de procurar o Estado- Juiz para que este preste a tutela jurisdicional. Assim, o que poderia ser compreendido como sendo de conhecimento, de execução ou cautelar é a tutela jurisdicional e não o processo ou a ação. ${ }^{20}$

O processo cautelar foi concebido no $\mathrm{CPC} / 73$ sob duas espécies, quais sejam, antecedente ou incidental, a depender do momento de sua instauração, ou seja, se fosse instaurado antes ou depois do pedido principal e tinha como uma de suas características a autonomia.

Dessa forma, eram antecedentes quando seu manejo se dava antes do processo principal, e uma vez deferida a providência postulada, o autor deveria ajuizar a demanda principal dentro de trinta dias, a contar da efetivação da medida. Caso contrário, a cautelar perderia a sua eficácia.

Ao revés, se o processo principal já estivesse tramitando, a cautelar proposta seria incidental.

\footnotetext{
${ }^{19}$ ZAVASCKI, Teori Albino. Antecipação de tutela. 5.ed. São Paulo: Saraiva, 2007. p.14-16.

20 BUENO, Cassio Scarpinella. Curso Sistematizado de direito processual civil: tutela antecipada, tutela cautelar e procedimentos cautelares específicos. São Paulo: Saraiva, 2009, v.4, p. 148-154.
} 
As medidas cautelares conservavam a sua eficácia durante esse lapso temporal de 30 dias e na pendência do processo principal, podendo ser revogadas ou modificadas se alteradas as suas circunstâncias.

O juiz poderia deferir providência cautelar antecipadamente no próprio processo cautelar, ou até mesmo antes da citação do réu e se esta medida cautelar viesse a perder a sua eficácia, o autor responderia de forma objetiva pelos prejuízos suportados pelo réu com a sua efetivação, ou seja, prescindível perquirir a presença de dolo ou culpa, uma vez que para a configuração da responsabilidade indenizatória, bastaria a presença do dano e o nexo de causalidade entre este e a efetivação da medida cautelar. O valor da indenização deveria ser liquidado nos próprios autos da ação cautelar.

A medida cautelar poderia ser substituída, de ofício ou a requerimento de qualquer das partes, pela prestação de caução ou de outra garantia menos gravosa para o requerido, sempre que adequada e suficiente para evitar lesão ou repará-la integralmente, e perdia sua eficácia caso não fosse ajuizada a ação principal no prazo de trinta dias, contado de sua efetivação, se não fosse executada dentro de 30 dias ou se o juiz declarasse extinto o processo principal.

Ademais, o CPC/73 consolidou a figura do poder geral de cautela, além de prever diversos procedimentos cautelares típicos. Sendo assim, podíamos vislumbrar duas técnicas cautelares.

Uma primeira técnica tinha como fundamento o poder geral do juiz, condicionada à presença dos requisitos genéricos do fumus boni iuris e do periculum in mora, com ampla liberdade do juiz para conceder a medida cautelar necessária ao caso concreto. Já a outra técnica era mais restrita, uma vez que adstrita a requisitos e parâmetros previamente elencados pelo legislador. A primeira referia-se ao poder geral de cautela, enquanto a segunda às cautelares típicas, específicas ou nominadas, isto é, aquelas tipificadas nos artigos 813 a 889 do $\mathrm{CPC} / 73$.

Os procedimentos cautelares específicos, típicos ou nominados à luz do CPC/73 são o arresto, o sequestro, a caução, a busca e apreensão, a produção antecipada de provas, os alimentos provisionais, o arrolamento de bens, o atentado, a posse em nome de nascituro, protestos, notificações e interpelações, justificação, nunciação de obra nova e outras medidas, como obras e conservação em coisa litigiosa, entrega de objeto e bens de uso pessoal da mulher e dos filhos, 
a posse provisória, a guarda e a educação dos filhos, o depósito de menor e o afastamento temporário de um dos cônjuges do casal.

É sabido que seria impossível ao legislador prever e regular todas as situações de risco que justificam a concessão de uma tutela de urgência. Por essa razão, a fim de concretizar o princípio da inafastabilidade de jurisdição, preconizado no artigo $5^{\circ}, \mathrm{XXXV}$ da $\mathrm{CF} / 88^{21}$, passou-se a se permitir a atuação do juiz nas mais diversas hipóteses de lesão ou ameaça a direito, resguardando e protegendo o resultado útil da própria atividade jurisdicional.

Segundo Cassio Scarpinella Bueno, no Código de Processo Civil de 1973, o poder geral de cautela estava previsto no artigo 798.

O artigo 798, ao lado de prever expressamente o dever -poder geral de cautela, bem realizando o artigo $5^{\circ}, \mathrm{XXXV}$, da $\mathrm{CRFB} / 88$, prevê também as medidas que o magistrado empregará para prestar adequada e suficientemente a tutela jurisdicional preventiva. De nada adiantaria com efeito, que a lei autorizasse ao magistrado reconhecer a existência de situações de perigo sem que lhe permitisse, em idêntica proporção, agir para debelá-las. A função jurisdicional não se esgota no reconhecer (dizer) o direito, mas, também, no seu realizar (satisfazer) na exata medida e para os mesmos fins em que suficientemente reconhecido. ${ }^{22}$

Assim, é consequência do poder geral de cautela a possibilidade de o juiz conceder uma cautelar inominada para tutelar as situações não tipificadas pelo legislador. Já as cautelares típicas eram aquelas expressamente preconizadas no $\mathrm{CPC} / 73$.

\subsection{1}

\section{Considerações gerais acerca da tutela antecipada à luz do CPC/73}

O instituto da tutela antecipada ganha contornos de generalidade em nosso ordenamento jurídico com o advento da Lei 8.952 de $13.12 .1994^{23}$, que ao dar nova redação ao artigo 273 do CPC/73, traz profundas mudanças ao nosso sistema processual brasileiro. Isto porque, o sistema até então vigente era informado pela necessidade de cognição exauriente ou decisão definitiva de mérito, para que só depois, se cogitasse de eventual produção de efeitos.

\footnotetext{
${ }^{21}$ Idem, nota n. 9.

${ }^{22}$ BUENO, Cassio Scarpinella, loc. cit., p. 186.

23 BRASIL. Lei $\mathbf{n}^{\mathbf{0}} \mathbf{8 . 9 5 2}$, de 13 de dezembro de 1994. Disponível em: < https:// presrepublica.jusbrasil.com.br/legislacao/103436/lei-8952-9 >. Acesso em: 5 dez. 2018.
} 
Com a previsão do instituto da antecipação de tutela para a generalidade dos casos, passa-se a ser permitido, mesmo que em caráter excepcional, uma tutela provisória, fundada em cognição sumária, com imediata efetividade.

Assim, podemos definir antecipação de tutela como sendo a possibilidade de antecipação dos efeitos de uma tutela jurisdicional, ou seja, o adiantamento dos efeitos de um futuro provimento de mérito, permitindo a fruição imediata pelo autor, daquilo que só teria a possibilidade de usufruir ao final do trâmite processual, isto é, após eventual sentença que excepcionalmente tivesse eficácia imediata, ou após julgamento do recurso de apelação, ou até mesmo após o trânsito em julgado da sentença.

José Carlos Barbosa Moreira à luz do CPC/73, deixa registrada uma crítica acerca dos termos ' tutela antecipada' e 'tutela antecipatória' quando utilizados indistintamente. Entendemos que tal crítica permanece, igualmente válida, à luz do $\mathrm{CPC} / 15$.

Permitam-me começar por uma observação de índole terminológica. Não é raro encontrar, até em escritos de alto nível científico, a expressão tutela antecipatória. Ela não é abonada nem pela linguagem da lei nem pela lógica gramatical. O texto vigente do art. 273 do CPC, na redação atual, alude a antecipação de tutela nos $\S \S$ $2^{\circ}$ e $5^{\circ}$ e a tutela antecipada nos $\S \S 3^{\circ}$ e $4^{\circ}$. Diz também, no caput, que o juiz poderá (...) antecipar os efeitos da tutela; e impõe a indicação clara e precisa das razões na decisão que antecipar a tutela. $\left(\S 1^{\circ}\right)$. Em lugar algum se depara a locução tutela antecipatória. Andou bem o legislador em expressar-se como expressou. Se por tutela se entende a proteção dispensada ao litigante, é intuitivo que ela não pode constituir o sujeito, mas apenas o objeto da antecipação. A tutela não antecipa seja o que for: pode, isso sim, ser antecipada pelo juiz, ou por decisão que este profira. Falar-se-á com propriedade, portanto, em decisão antecipatória ou em providência antecipatória, no sentido de decisão ou de providência que antecipa a tutela. Quanto a esta última, ou será antecipada ou não o será: antecipatória é que jamais se concebe que seja. ${ }^{24}$

Devemos salientar, no entanto, que a antecipação de tutela, mesmo antes de 1994 era preconizada, porém somente era cabível em determinados procedimentos especiais, como por exemplo, o mandado de segurança, as ações possessórias, dentre outros. Em razão da ausência de regramento legal estendendo a técnica da tutela antecipada para a generalidade dos casos, nos processos em geral, diante de uma situação urgente, a parte valia-se da via cautelar, mais precisamente do poder geral de cautela, na tentativa de antecipar os efeitos materiais da tutela pretendida.

${ }^{24}$ MOREIRA, José Carlos Barbosa. Antecipação de tutela: algumas questões controvertidas.

Temas de direito Processual- Oitava série. São Paulo: Saraiva, 2004. p. 77-888. 
Tal era o expediente utilizado na praxe forense, à míngua de outro mecanismo para a tutela de urgência.

Portanto, com o advento da nova redação do artigo 273 do CPC/73, estendese a antecipação dos efeitos da tutela para a generalidade dos casos, bastando para tanto, o preenchimento de certos requisitos legais.

Nos termos de seu artigo 273, o juiz, a requerimento da parte, poderia antecipar, no todo ou em parte, os efeitos da tutela jurisdicional, desde que houvesse verossimilhança nas alegações, fundada em prova inequívoca e, ainda houvesse risco de grave lesão ou de difícil reparação ou se verificasse ser abusiva ou protelatória a defesa do réu. Contudo, vedava a concessão da tutela antecipada quando houvesse risco de irreversibilidade do provimento final.

Em 2002, com a introdução de novas regras mediante modificação legislativa, a tutela antecipada passou também a ser destinada ao cumprimento de obrigação de fazer, não fazer e de entrega de coisa, conforme previsão nos artigos 461 e 461- A do CPC/73, tendo como fundamentos para a sua concessão, a coexistência da relevância do argumento e do justificado receio de ineficácia do provimento final, requisitos que para Sérgio Cruz Arenhart "se equiparavam ao fumus boni iuris e ao periculum in mora" 25

O 461 do CPC/73 servia também de fundamento para a concessão da tutela inibitória, através da demonstração de um ilícito a ser perpetrado pelo réu ou já consumado, sendo prescindível a comprovação de dano, culpa e dolo. Isto porque, bastava a demonstração da ameaça da prática de um ato ilícito.

$\mathrm{O}$ artigo $273 \S 6^{\circ}$ do $\mathrm{CPC} / 73$ preconizava a concessão da tutela antecipada com fundamento na incontrovérsia dos pedidos ou de parcela deles. Nesse caso, não era necessário que o juiz analisasse a presença do perigo de dano irreparável ou de difícil reparação, não se cogitando, outrossim, da ausência de risco de irreversibilidade ou a presença do manifesto propósito protelatório do réu. Isto porque, nessa hipótese, o juiz concedia a tutela antecipada não apenas com fulcro num juízo de verossimilhança, mas fundado num exame de certeza. Tanto é assim, que o CPC/15 não possui dispositivo legal equivalente. No seu lugar, agora há a previsão no artigo 356 do CPC/15 do julgamento antecipado parcial de mérito.

${ }^{25}$ ARENHART, Sérgio Cruz. A tutela inibitória da vida privada. São Paulo: Revista dos Tribunais, 2000. P. 119. 
Já artigo $273 \S 7^{\circ}$ do CPC/73 previa que "se o autor, a título de antecipação de tutela, requerer providência de natureza cautelar, poderá o juiz, quando presentes os respectivos pressupostos, deferir a medida cautelar em caráter incidental no processo ajuizado". Parte da doutrina afirmava que tal dispositivo concebia uma fungibilidade entre a medida cautelar e a tutela antecipada. 


\section{Distinção entre tutela cautelar e tutela antecipada}

A tutela cautelar representa a concessão de providências que assegurem a efetividade de uma pretensão discutida em outro processo. Segundo Piero Calamandrei, há, portanto, nos procedimentos cautelares, mais do que o objetivo de aplicar o direito, a finalidade imediata de assegurar a eficácia do procedimento definitivo que servirá por sua vez ao direito.

A tutela cautelar é, em comparação ao direito substancial, uma tutela mediata: mais do que fazer justiça, serve para garantir o eficaz funcionamento da justiça. Se todos os procedimentos jurisdicionais são um instrumento de direito substancial que, através destes, se cumpre, nos procedimentos cautelares verifica-se uma instrumentalidade qualificada, ou seja, elevada por assim dizer, ao quadrado: estes são de fato, infalivelmente, um meio predisposto para o melhor resultado do procedimento definitivo, que por sua vez é um meio para a aplicação do direito; são, portanto, em relação à finalidade última da função jurisdicional, instrumentos do instrumento. ${ }^{26}$

Portanto, a tutela cautelar visa evitar que outra demanda perca a sua efetividade.

Já a tutela antecipada tem por escopo antecipar os efeitos da sentença de mérito, tratando-se de técnica que se aplica em qualquer processo, inclusive ao processo cautelar.

Conceitua João Batista Lopes, que a antecipação de tutela:

Trata-se, portanto, de decisão interlocutória (e não de sentença), por via da qual o juiz concede ao autor o aditamento de efeitos da sentença de mérito com caráter satisfativo. Não se cuida, pois, de julgamento antecipado da lide, como se verá mais adiante, mas de medida de caráter provisório que visa a tutelar mais eficaz e prontamente o direito do autor sempre que ele preencher os requisitos exigidos pela lei. ${ }^{27}$

\footnotetext{
${ }^{26}$ CALAMANDREI, Piero. Introdução ao estudo sistemático dos procedimentos cautelares. Trad. Carla Roberta Andreasi Bassi. Trad. ed. Italiana, 1936. Campinas: Servanda, 2000. p. 42.

${ }^{27}$ LOPES, João Batista. Tutela Antecipada no Processo Civil Brasileiro. 2. ed. São Paulo: Saraiva, 2003. p. 50.
} 
Diante desse instituto que foi trazido em caráter geral para o $\mathrm{CPC} / 73 \mathrm{com}$ a Lei 8952/94, é possível a concessão dos efeitos da sentença, em qualquer processo, o que também foi mantido pelo Código de Processo Civil de 2015, que preconiza em seu artigo 294 a possibilidade de concessão de tutela provisória antecipada antecedente ou incidental.

Seguindo a lição de Luiz Guilherme Marinoni, a referibilidade ao direito acautelado é pressuposto necessário da tutela cautelar, ou seja, o provimento cautelar deve guardar referência a um direito acautelado. A falta de referibilidade indica satisfatividade. Nas palavras do processualista:

A falta de referibilidade, como se vê, é evidência da inexistência de cautelaridade. $\mathrm{Na}$ tutela satisfativa inexiste referibilidade a um direito acautelado. É o caso da ação de alimentos provisionais. Aí não há referibilidade, porque nada é assegurado. $^{28}$

No entanto, uma observação se faz necessária. Apesar de o Brasil ter se debruçado, com rigor técnico para diferenciar medidas antecipatórias e conservativas, tal preocupação, contudo, não é a de outros países. O direito português, ao tratar da técnica cautelar, o que equivale ao poder geral de cautela de nosso direito pátrio, não faz distinção entre as medidas antecipatórias e cautelares. Nesse mesmo sentido é o direito italiano, que igualmente não faz distinção entre a técnica cautelar e antecipatória, como se pode perceber no artigo 700 do Codice- Provvedimenti d' urgenza, donde se extrai que os provimentos antecipatórios estão inseridos no processo cautelar.

\footnotetext{
${ }^{28}$ MARINONI, L. G., op. cit., p. 112.
} 


\section{Classificação das tutelas de urgência: tutela cautelar e tutela antecipada como espécies do gênero da tutela de urgência}

Podemos encontrar na doutrina diversas definições e classificações acerca da tutela de urgência. Todavia, independentemente da classificação que se adote, a tutela de urgência não pode prescindir de seu elemento principal, qual seja, a urgência, isto é, a necessidade de uma tutela que viabilize uma atuação que tenha por escopo evitar um dano irreparável ou de difícil reparação. Sendo assim, podemos defini-la como técnica processual que visa impedir a consumação ou o agravamento de um dano, diante da necessidade de uma solução imediata.

Nesse sentido, Eduardo de Avelar Lamy assevera que:

a tutela jurisdicional tem natureza urgente quando cuidar de situações em que determinado pronunciamento jurisdicional necessitar ser proferido em curto período de tempo, através de cognição sumária, por meio de técnicas antecipatórias ou assecuratórias, dada a possibilidade de dano ao direito material envolvido. Portanto, a tutela de urgência corresponde ao resultado rápido que a jurisdição, através do processo, não pode deixar de atingir em muitas e frequentes situações do cotidiano. Trata-se do gênero de tutela que se destina a evitar danos oriundos da demora na prestação jurisdicional, ou da necessidade existente, conforme a natureza do direito material protegido, de obter-se pronunciamento jurisdicional antes do exaurimento da cognição, para que a prestação jurisdicional seja tempestiva e efetiva. ${ }^{29}$

Por oportuno, trazemos à baila algumas das diversas classificações de tutela de urgência, propostas pela doutrina.

Ovídio A. Baptista da Silva, afirma que a tutela de urgência pode apresentar-se sob três modalidades distintas:

(i) tutela propriamente cautelar; (ii) tutela concedida através de liminares satisfativas, sob forma de medidas provisórias, de tipo interdital, a ser depois confirmadas ou revogadas por sentenças que vier a ser proferida no 'processo principal; (iii) formas de tutela satisfativa autônoma, por dispensarem propositura

\footnotetext{
${ }^{29}$ LAMY. Eduardo de Avelar. Flexibilização da tutela de urgência. 2. ed. Curitiba: Juruá, 2007. p. 2.
} 
de uma demanda plenária subsequente, a ser ajuizada, como nas duas hipóteses anteriores por quem haja obtido a tutela de urgência satisfativa ${ }^{30}$.

Teori Albino Zavasck assevera que as tutelas de urgência são necessariamente provisórias, contrapondo-se à ideia de segurança e solução definitiva para o litígio.

Aponta o jurista que:

tal modalidade de tutela prestigia o fator efetividade e se caracteriza pela (i) referibilidade a um pedido de tutela definitiva, (ii) situação de urgência assim entendida como situação fática que, de alguma forma, compromete a regular prestação definitiva, (iii) cognição sumária, (iv) eficácia limitada no tempo, (v) inexistência de coisa julgada, permitindo a modificação ou revogação, a qualquer tempo, desde que haja mudança no estado de fato ou de prova. ${ }^{31}$

José Roberto dos Santos Bedaque por sua vez, entendendo que a tutela de urgência é decidida sob um juízo de cognição sumária, também divide as tutelas de urgência em duas espécies: as definitivas, aptas a definir o litígio de forma definitiva e a de natureza cautelar, apta a trazer tão somente soluções provisórias. Para uma melhor compreensão, transcreve-se as palavras do jurista:

Existem, ainda, as tutelas de urgência, precedidas de cognição sumária, que podem ser divididas em definitivas e provisórias. Aquelas, como as de cognição exauriente, são aptas a definir o litígio no sentido de que representam a resposta final obtida no âmbito jurisdicional. Caracterizam-se, porém, pela sumariedade da cognição. As últimas, também precedidas de cognição sumária, são prestadas de forma urgente, mas constituem soluções provisórias, com função de mera segurança para o resultado final. Não são aptas a produzir esse resultado, mas contribuem para que ele possa se verificar com a maior dose de utilidade possível. Estas, apesar de especificidade quanto ao conteúdo, podem ser reunidas em uma única categoria, caracterizadas que são pela provisoriedade e pela instrumentalidade. Em síntese, as tutelas de urgência podem ser definitivas ou provisórias. $^{32}$

Como se percebe, há diversas formas de classificação das tutelas de urgência espraiadas em nossa doutrina pátria. Por isso, para uma melhor compreensão, traçaremos algumas de suas características.

\footnotetext{
${ }^{30}$ SILVA, Ovídio A. Batista da. Teoria Geral do Processo. São Paulo: Revista dos Tribunais, 2002.

${ }^{31}$ ZAVASCKI, T. A., op. cit., p. 40.

${ }^{32}$ BEDAQUE, J. R. dos S., op. cit., p. 115.
} 


\section{6 \\ Características das tutelas provisórias}

\section{1 Características comuns à tutela cautelar e a antecipação de tutela}

A tutela cautelar e a tutela antecipada têm a mesma função no sistema processual civil, ou seja, estão vocacionadas para assegurar a eficácia do resultado final. Ambas possuem características comuns, dentre as quais podemos destacar a inércia, provisoriedade, revogabilidade, fungibilidade e sumariedade da cognição.

A inércia, como bem mencionada por Leonardo Greco, dentre outros doutrinadores, é característica da tutela provisória. Trata-se de garantia fundamental do processo civil, segundo a qual a jurisdição civil somente se exerce por provocação de algum interessado, nos limites da demanda proposta. Essa é uma garantia da liberdade dos cidadãos frente ao Estado, prestigiando a independência e imparcialidade da própria jurisdição e de quem a exerce.

Afirma o autor que:

( ..) "Na tutela provisória não é diferente. Todas a suas espécies somente podem ser exercidas por iniciativa de uma das partes interessadas, e não por iniciativa ex officio do juiz. Essa característica permanece presente com o advento do CPC/15, pois de acordo com seus artigos $2^{\circ}$ e 490 , o processo civil começa por iniciativa das partes sendo vedado ao juiz proferir decisão de natureza diversa da pedida, bem como condenar a parte em quantidade superior ou em objeto diverso do que lhe foi demandado." $" 33$

Nesse sentido, já se manifestou o STJ:

Processo civil. Recurso especial. Ação civil pública. Tutela antecipada. Necessidade de requerimento. Dissídio jurisprudencial. Ausente.

1. Ambas as espécies de tutela - cautelar e antecipada - estão inseridas no gênero das tutelas de urgência, ou seja, no gênero dos provimentos destinados a tutelar situações em que há risco de comprometimento da efetividade da tutela jurisdicional a ser outorgada ao final do processo. 2. Dentre os requisitos exigidos para a concessão da antecipação dos efeitos da tutela, nos termos do art. 273 do $\mathrm{CPC}$, está o requerimento da parte, enquanto que, relativamente às medidas

33 GRECO. Leonardo. A tutela de urgência e de evidência no Código de Processo Civil de 2014/2015. Revista Eletrônica de Direito Processual - REDP. p. 185-209. 
essencialmente cautelares, o juiz está autorizado a agir independentemente do pedido da parte, em situações excepcionais, exercendo o seu poder geral de cautela (arts. 797 e 798 do CPC).

3. Embora os arts. 84 do CDC e 12 da Lei $7.347 / 85$ não façam expressa referência ao requerimento da parte para a concessão da medida de urgência, isso não significa que, quando ela tenha caráter antecipatório, não devam ser observados os requisitos genéricos exigidos pelo Código de Processo Civil, no seu art. 273. Seja por força do art. 19 da Lei da Ação Civil Pública, seja por força do art. 90 do CDC, naquilo que não contrarie as disposições específicas, o CPC tem aplicação.

4. A possibilidade de o juiz poder determinar, de ofício, medidas que assegurem o resultado prático da tutela, dentre elas a fixação de astreintes (art. $84, \S 4^{\circ}$, do CDC), não se confunde com a concessão da própria tutela, que depende de pedido da parte, como qualquer outra tutela, de acordo com o princípio da demanda, previsto nos art. $2^{\circ}$ e 128 e 262 do CPC.

5. Além de não ter requerido a concessão de liminar, o MP ainda deixou expressamente consignado a sua pretensão no sentido de que a obrigação de fazer somente fosse efetivada após o trânsito em julgado da sentença condenatória.

6. Impossibilidade de concessão de ofício da antecipação de tutela.

7. Recebimento da apelação no efeito suspensivo também em relação à condenação à obrigação de fazer.

8. Recurso especial parcialmente provido. ${ }^{34}$

No entanto, essa característica não é unânime entre os doutrinadores, bem como no âmbito do STJ, existe precedentes em sentido contrário àquele acima colacionado.

Para essa outra corrente doutrinária, tanto a tutela cautelar como a tutela antecipada podem, excepcionalmente ser concedidas de ofício.

Por oportuno, transcreve-se os julgados do STJ:

Processual civil e previdenciário. Rural. Aposentadoria por invalidez. Concessão de tutela antecipada de ofício pela corte de origem. Alegação de ausência de pedido por parte do segurado. Petição inicial redigida de forma singela, mas que contém os elementos que indicam os fatos, os fundamentos e o pedido para a implementação do benefício a partir da citação, o que denota pretensão pelo provimento antecipado. Vício afastado. Implementação imediata do pagamento mensal do benefício por outro fundamento. Art. 461 do cpc. Comando mandamental do acórdão recorrido.

1. Hipótese na qual o INSS pleiteia o reconhecimento de ofensa ao artigo 273 do CPC ao argumento de que a tutela antecipada para a implementação do benefício foi deferida pelo acórdão recorrido ex officio.

2. Deve ser mantida a implementação da aposentadoria por invalidez diante das peculiaridades do caso, pois a petição inicial, apesar de singela, traz pedido antecipatório ao requerer a implementação do benefício a partir da citação do réu.

\footnotetext{
${ }^{34}$ BRASIL. Jurisprudência. Acórdão unânime da Terceira Turma do STJ, REsp. 1178500/SP. rel. Min. Nancy Andrighi, j. 04/12/2012. DJe 18/12/2012.
} 
3. No caso, a ordem judicial para a implantação imediata do benefício deve ser mantida. Não com fulcro no artigo 273 do CPC, mas sim com fundamento no artigo 461 do CPC, pois o recurso sob exame, em regra, não tem efeito suspensivo, o segurado obteve sua pretensão em primeira e segunda instâncias e a implementação do benefício é comando mandamental da decisão judicial a fim de que o devedor cumpra obrigação de fazer. Salvaguarda-se, desse modo, a tutela efetiva. A propósito, confiram-se: AgRg no REsp 1056742/RS, Rel. Min. Napoleão Nunes Maia Filho, Quinta Turma, DJe 11/10/2010; e REsp 1063296/RS, Rel. Min. Og Fernandes, Sexta Turma, DJe 19/12/2008.

4. Recurso especial não provido. ${ }^{35}$

Ementa processual civil. Previdenciário. Salário-maternidade. Tutela antecipada de ofício concedida no acórdão. Admissibilidade em hipóteses excepcionais.

1. Trata-se, na origem, de Ação Declaratória com pedido de condenação ao pagamento de salário-maternidade movida por trabalhadora rural diarista. O acórdão confirmou a sentença de procedência e, de ofício, determinou a imediata implantação do mencionado benefício.

2. As tutelas de urgência são identificadas como reação ao sistema clássico pelo qual primeiro se julga e depois se implementa o comando, diante da demora do processo e da implementação de todos os atos processuais inerentes ao cumprimento da garantia do devido processo legal. Elas regulam situação que demanda exegese que estabeleça um equilíbrio de garantias e princípios (v.g., contraditório, devido processo legal, duplo grau de jurisdição, direito à vida, resolução do processo em prazo razoável).

3. No caso concreto, o Tribunal se vale da ideia de que se pretende conceder salário-maternidade a trabalhadora rural (boia-fria) em virtude de nascimento de criança em 2004.

4. O Superior Tribunal de Justiça reconhece haver um núcleo de direitos invioláveis essenciais à dignidade da pessoa humana, que constitui fundamento do Estado Democrático de Direito. Direitos fundamentais correlatos às liberdades civis e aos direitos prestacionais essenciais garantidores da própria vida não podem ser desprezados pelo Poder Judiciário. Afinal, "a partir da consolidação constitucional dos direitos sociais, a função estatal foi profundamente modificada, deixando de ser eminentemente legisladora em pró das liberdades públicas, para

35 BRASIL. Jurisprudência. Acórdão não unânime da Primeira Turma do STJ. REsp. 1.319.769/GO, rel. Min. Sérgio Kukina, rel. p/ acórdão Min. Benedito Gonçalves, j. 20.8.2013, DJe 20.9.2013. 
se tornar mais ativa com a missão de transformar a realidade social. Em decorrência, não só a administração pública recebeu a incumbência de criar e implementar políticas públicas necessárias à satisfação dos fins constitucionalmente delineados, como também, o Poder Judiciário teve sua margem de atuação ampliada, como forma de fiscalizar e velar pelo fiel cumprimento dos objetivos constitucionais". (REsp 1.041.197/MS, Rel. Min. Humberto Martins, Segunda Turma, DJe 16.9.2009.)

5. A doutrina admite, em hipóteses extremas, a concessão da tutela antecipada de ofício, nas "situações excepcionais em que o juiz verifique a necessidade de antecipação, diante do risco iminente de perecimento do direito cuja tutela é pleiteada e do qual existam provas suficientes de verossimilhança" 36

6. A jurisprudência do STJ não destoa em situações semelhantes, ao reconhecer que a determinação de implementação imediata do benefício previdenciário tem caráter mandamental, e não de execução provisória, e independe, assim, de requerimento expresso da parte (v. AgRg no REsp 1.056.742/RS, Rel. Min. Napoleão Nunes Maia Filho, DJe de 11.10.2010 e REsp 1.063.296/RS, Rel. Min. Og Fernandes, DJe de 19.12.2008).

7. Recurso Especial não provido. ${ }^{37}$

Assim, nos termos da jurisprudência acima colacionada, poderá ser concedida excepcionalmente a tutela de urgência, quando o juiz verificar diante do caso concreto, a necessidade de sua concessão, sob pena de perecimento do direito e/ou grave prejuízo, a fim de prestigiar o acesso à justiça e a efetividade da tutela jurisdicional.

A próxima característica a ser mencionada é a provisoriedade.

A tutela cautelar e a tutela antecipada não são analisadas sob um juízo de certeza do direito, bastando para a sua concessão, ao lado do periculum in mora, a existência de fumus boni iuris, o que denota uma cognição sumária, não exauriente. Justamente por isso, não tem vocação para a definitividade, tendo como marca característica a provisoriedade, isto é, qualquer que seja o tipo de providência judicial pleiteada, com base em situação de risco, será sempre marcada pelo signo da impermanência.

\footnotetext{
${ }^{36}$ BEDAQUE, J. RE. Dos S., op. cit., 4. ed., 2006. p. 384-385.

37 BRASIL. Jurisprudência. Acórdão unânime da Segunda Turma do STJ. REsp. 1.309.137/MG, rel. Min. Herman Benjamin, j. 8.5.2012, DJe22.5.2012.
} 
Acerca dessa característica, podemos mencionar a lição de Andrea Proto Pisani, que analisa a provisoriedade sob o ponto de vista temporal. Assevera o jurista italiano que:

o provimento cautelar, enquanto resultante de uma base de cognição sumária e não plena, é por sua natureza provisório no sentido de que nunca será capaz de reger em modo definitivo os efeitos que agora se verificam, ainda que quanto ao seu conteúdo sejam totalmente antecipatórios de provimento futuro baseado em cognição plena." 38

Com efeito, o provimento urgente não é suscetível de produzir efeitos definitivos no processo, uma vez que essa condição é reservada ao provimento exauriente, dependente de cognição plena.

A provisoriedade, em questão, não está relacionada unicamente a um caráter temporal, mas sim, a um aspecto instrumental no que se refere à inaptidão para oferecer uma solução de mérito imutável.

Nessa condição de oferecer apenas regulação provisória da lide, é que os procedimentos urgentes são tidos como contextuais e não destinados a produzir efeitos definitivos.

Assim, podemos dizer que de um lado a provisoriedade da tutela provisória é baseada por uma cognição sumária e, justamente por isso, poderá vir a ser revogada e/ ou modificada, e de outro, está fadada a ser substituída por uma tutela definitiva.

No CPC/15 a provisoriedade, no sentido acima mencionado, de tutela temporária de um provável direito, está preconizada no artigo 296, que determina que a tutela de urgência e a tutela de evidência conservam a sua eficácia na pendência do processo principal, podendo, a qualquer tempo, ser revogada ou modificada. Com efeito, a tutela de urgência e de evidência não têm aptidão para a tutela definitiva do provável direito do requerente, que deverá ser objeto de um provimento no processo principal.

No caso da tutela de urgência, essa provisoriedade deve ser interpretada à luz dos $303 \S 2^{\circ}$ e 308 do $\mathrm{CPC} / 15$, que exigem o aditamento da inicial e quinze dias para a formulação do pedido principal, no caso de tutela antecipada, ou de

\footnotetext{
${ }^{38}$ PISIANI, Andrea Proto. Lezioni di Diritto Processuale Civile. Napoli: Jovene Editore, 1999. p. 637.
} 
propositura da ação principal em trinta dias, no caso de tutela cautelar, sob pena de caducidade da referida tutela provisória concedida.

Já a revogabilidade é consequência da provisoriedade, uma vez que havendo alteração na situação de fato, podem vir a ser revogadas.

Essa é a razão porque Massimo Cirulli aponta com precisão, que a revogabilidade está intimamente ligada ao caráter instrumental e, assim, típico de provimentos provisórios.

João Batista Lopes afirma que "precisamente por ter caráter provisório, é concedida rebus sic stantibus. Assim, persistindo o estado de perigo, não pode o juiz, imotivadamente, revogar a medida."39

Dessa forma, a solução para a questão da revogabilidade da tutela de urgência, seja cautelar ou tutela antecipada, reside na necessidade de comprovação de novos elementos, ou seja, de uma ampliação da cognição do juiz. Em relação a esse ponto da revogabilidade, convém mencionar que na Itália, só se admite a revogação ou modificação dos provimentos urgentes se ocorrerem mudanças das circunstâncias, conforme adverte Fabio Fiorucci.

A revogabilidade é também característica da tutela de evidência. Nessa hipótese, apesar de o direito invocado pela parte se mostrar com um grau de probabilidade tão elevado, que se torna evidente, a tutela de evidência, contudo se diferencia do julgamento antecipado do mérito. Isto porque, aquela é baseada em cognição sumária, traduzindo, portanto, decisão revogável e provisória, ao contrário do julgamento antecipado que é analisado sob um juízo de certeza, ou seja, em sede de cognição exauriente.

Outrossim, podemos mencionar como característica da tutela provisória, de urgência ou de evidência, a sumariedade da cognição.

Kazuo Watanabe, ao se referir à cognição sumária no campo da tutela de urgência, faz menção a um juízo de cognição menos aprofundado verticalmente. Adverte que:

não se ignora a diferenciação entre plausibilidade, possibilidade, verossimilhança e probabilidade, todas as expressões usadas para definir maior ou menor grau de convencimento e tratadas de forma não unívoca pelos autores. Nenhuma delas, contudo, confunde-se com a certeza que importa na plena convicção. Não nos interessa, por ora, adentrar na seara conceitual, daí por que utilizamos a expressão

\footnotetext{
${ }^{39}$ LOPES, J. B.,2003, op. cit,. p. 81.
} 
plausibilidade para definir, simplesmente, um estado de convencimento provisório, alijados de elementos que o conduzam à certeza. ${ }^{40}$

No entanto, conforme assevera o referido jurista, a convicção do juiz, na cognição sumária, apresenta diferentes graus. Deve haver adequação da intensidade do juízo de probabilidade ao momento procedimental da avaliação, à natureza do direito alegado, à espécie dos fatos afirmados, à natureza do provimento a ser concedido, enfim, à especificidade do caso concreto. Em razão da função que cumpre a cognição sumária, mero instrumento para a tutela de um direito, e não para a declaração de sua certeza, o grau máximo de probabilidade é excessivo, inoportuno e inútil ao fim a que se destina. ${ }^{41}$

É por essa razão que a tutela concedida com fulcro em cognição sumária não transita materialmente me julgado.

O CPC/15 também traz a cognição sumária como característica da tutela provisória, uma vez que a simples caracterização das tutelas de urgência e de evidência como tutelas provisórias resulta do reconhecimento de que são o fruto de uma cognição não exauriente.

Pela leitura das disposições gerais trazidas pelo CPC/15, está evidente a inaptidão da tutela provisória à formação da coisa julgada e a limitação cognitiva que poderá ser superada, no mesmo ou em outro processo, pela cognição mais ampla.

Todavia, existem importantes diferenças entre a cognição sumária que se exige para a concessão de uma tutela de urgência e de uma tutela de evidência, pois além de uma gradação quanto ao grau de convencimento do juiz, na tutela de urgência há maior liberdade ao juiz, que agirá à luz do caso concreto, diferentemente do que ocorre na tutela de evidência, pois a atuação do juiz é de subsunção aos ditames legais.

\section{2}

\section{Características específicas da tutela cautelar de urgência}

A primeira característica referente à tutela cautelar é a instrumentalidade, uma vez que o processo cautelar pode ser definido como um instrumento para a

\footnotetext{
${ }^{40}$ WATANABE, Kazuo. Da Cognição no processo civil. 4. ed. São Paulo: Saraiva, 2012. p. 123.

${ }^{41}$ Ibidem, p. 128.
} 
proteção do processo de conhecimento e/ou de execução. Isto porque, o processo cautelar não tem por escopo a proteção imediata do direito material, visando na realidade salvaguardar a utilidade do processo principal. Trata-se, portanto, de uma tutela mediata do direito material, ficando a tutela direta e imediata reservada ao processo dito principal.

Nas palavras de Humberto Theodoro Jr:

Sua eficácia sobre a lide - que retrata o conflito de interesses no âmbito do direito substancial - é apenas mediata, por meio de outro processo. A eficácia imediata é, no entanto, sentida sobre o processo principal, que, qualquer que seja sua conclusão, pode contar com a medida cautelar como um precioso instrumento de segurança e eficácia para a sua atuação na composição definitiva da lide. ${ }^{42}$

Luiz Guilherme Marinoni, no entanto, adverte que apesar de a tutela cautelar não estar vinculada ao reconhecimento do direito material que será discutido na ação principal, está igualmente vocacionada à sua proteção.

A segunda característica a ser apresentada é a referibilidade. Segundo Luiz Guilherme Marinoni, a referibilidade ao direito acautelado é pressuposto necessário da tutela cautelar. A ideia de referibilidade contrapõe-se a de satisfatividade, ou seja, a primeira é indicativa de cautelaridade, enquanto a segunda se refere a uma tutela sumária satisfativa. ${ }^{43}$

Portanto, por meio dessa característica, podemos concluir que o provimento cautelar deve guardar referência a um direito acautelado, qual seja, aquele que se visa assegurar e que será objeto de definição no processo principal.

A terceira característica é a autonomia e acessoriedade. Sob a égide do $\mathrm{CPC} / 73$, mencionava-se como característica do processo cautelar a autonomia. $\mathrm{O}$ CPC/15, no entanto, extinguiu a autonomia do processo cautelar, rompendo com a tradição até então adotada em nosso sistema jurídico, passando a prever como característica a acessoriedade.

A quarta característica é a fungibilidade cautelar. Primeiramente devemos assentar que alguns princípios não contêm uma proposição jurídica reguladora de conduta, pois funcionam, no mais das vezes, como meios sistemáticos construídos em função da necessidade de estabelecer uma ponderação de valores, a fim de permitir um adequado ajustamento no caso de contradição. Essas contradições

\footnotetext{
${ }^{42}$ THEODORO JR, Humberto. Processo cautelar. 24. ed. São Paulo: Leud, 2008. p. 49.

${ }^{43}$ MARINONI, L. G., op. cit., p. 10-112.
} 
entre princípios, conforme fartamente analisado anteriormente, não são consideradas como verdadeiras contradições à medida que o próprio sistema estabelece meios para a sua superação. Assim, podemos afirmar que o processo civil se assenta em diversos princípios fundamentais, que quando em conflito, dão ensejo ao compromisso representado pelo da fungibilidade.

O processo civil, entendido como relação jurídica processual, desdobra-se por meio de atos processuais regulados do ponto de vista formal.

Pontes de Miranda, analisando o assunto de forma profunda, estabeleceu como regra, que eleita uma forma de realização de atos processuais ao ponto que legislada, não haveria como executá-los de outra maneira.

Nas palavras do ilustre processualista "quando a lei escolhe um modo de pratica-lo, em vez de outros modos possíveis, tem-se de entender que excluiu a esses e considerou aquele como único." ${ }^{44}$

Nesse sentido, é de se reconhecer que já houve um momento em que prevaleceu o princípio da regulação das formas em nosso ordenamento jurídico, identificado como princípio da relevância das formas processuais. ${ }^{45}$

Esse princípio da regulação das formas, mais do que mera prescrição burocrática, tinha a finalidade de permitir o controle do desenvolvimento do processo e das próprias decisões fundamentais, tendo como fundamento o controle exercitável pelas partes e pela sociedade sobre o curso do processo, e também sobre a atividade jurisdicional nele praticada.

A importância desse princípio, no entanto, foi amplamente reduzida a partir do $\mathrm{CPC} / 73$, à medida que se estabeleceu um sistema de tolerância às infrações formais, nos termos do artigo 244.

A esse respeito, Pontes de Miranda afirmava a ocorrência de "imenso golpe que vibrava na armadura clássica do processo." 46

Assim, o princípio da regulação das formas foi flexibilizado pelo princípio da instrumentalidade, tornando-se infrações formais irrelevantes, desde que atingida a finalidade pretendida. Nesse sentido, a infração formal somente gera nulidade do ato à proporção que esta sanção lhe tenha sido especificamente cominada.

\footnotetext{
${ }^{44}$ MIRANDA, Pontes de. Comentários ao Código de Processo Civil. Rio de Janeiro: Forense, 1996. Tomo III, p. 368.

${ }^{45}$ Ibidem, p. 370.

${ }^{46}$ Ibidem, p. 368.
} 
A esse respeito, Ovídio Batista assevera que "todas as regras sobre formas são imperativas e devem ser respeitadas, sob pena de contaminação do ato. O rigorismo, entretanto, é amainado ante a sobreposição de outros princípios e regras." $" 47$

Ao lado dessa imposição formal, há o princípio de acesso à justiça. Em relação ao ponto, Dinamarco assevera que "as regras processuais não têm valor absoluto que se sobrepõe hoje as do direito substancial e as exigências sociais de pacificação dos conflitos e conflitantes." ${ }^{48}$

Como se percebe, quando ocorre uma situação de conflito entre princípios, gerada pela deficiência objetiva de regras processuais ou da própria decisão judicial, a solução sistemática se corporifica no ajustamento entre eles, geralmente realizado pela incidência de outro princípio, desta feita, de natureza aberta. No caso em tela, o princípio que tem por escopo gerar esse equilíbrio é o princípio da fungibilidade. Esse princípio concilia a necessidade de tutela jurídica com a necessidade de atendimento das formas legais, e isso ocorre na medida em que determinada finalidade processual pode ser obtida a despeito de não estar predisposto para isso do ponto de vista formal.

Esse aspecto foi destacado por Cheim Jorge quando a respeito asseverou que:

A possibilidade de utilização do princípio da fungibilidade está vinculada a duas vicissitudes. A primeira liga-se à circunstância de se evitar o formalismo excessivo (...). A segunda, e talvez a mais contundente, é revelada pela especial circunstância de um erro de sistema. ${ }^{49}$

Dessa forma, o princípio da fungibilidade tem por escopo concretizar o amplo acesso à justiça e a efetividade da tutela jurisdicional.

Nas palavras de Tereza Arruda Alvim, "o princípio da fungibilidade é descendente direto do princípio da instrumentalidade das formas, que é mais genérico, e significa que, preenchidas determinadas condições, tanto um meio, quanto outro podem ser empregados para se chegar a determinado resultado."

\footnotetext{
${ }^{47}$ SILVA, O. A. B. da., op. cit., p. 234.

${ }^{48}$ DINAMARCO, Candido Rangel. Instrumentalidade do Processo. São Paulo: Malheiros, 2002. p. 236.

49 JORGE, Flávio Cheim. Teoria Geral dos Recursos Cíveis. 5. ed. São Paulo: Revista dos Tribunais, 2012. p. 220.

${ }^{50}$ WAMBIER, Tereza Arruda Alvim. Nulidades do processo e da sentença. 6. ed. São Paulo: Revista dos Tribunais, 2007. p. 492.
} 
Especificamente no que tange à tutela cautelar, a doutrina afirma que vigora um princípio geral de adequação, através do qual, há fungibilidade entre as cautelares, de modo a possibilitar a substituição de uma por outra, a fim de compatibilizar a tutela às necessidades do caso concreto, desde que observados certos limites.

A doutrina também traz uma outra abordagem à luz do CPC/73 acerca da fungibilidade, afirmando a possibilidade de aplica-la entre uma cautelar típica e uma cautelar atípica.

Convém salientar, no entanto, que não havia consenso doutrinário quanto ao ponto. A fim de demonstrar a divergência, podemos citar de um lado, Araken de Assis, o qual defendia "a impossibilidade de adoção de medidas atípicas se existissem no ordenamento meios típicos previstos para a espécie"51 e de outro, podemos mencionar José Miguel Garcia Medina, Fábio Caldas de Araújo e Fernando da Fonseca Gajardoni que, em obra conjunta, defendem opinião contrária.

Assim, com fulcro na fungibilidade, parte da doutrina vinha admitindo a concessão da tutela cautelar correta, quando a parte havia formulado pedido de tutela cautelar inadequada ao caso concreto, desde que respeitados certos limites.

Para Medina, Araújo e Gajardoni, "não se trata propriamente de aplicação de fungibilidade nesse caso, mas de incidência do princípio segundo o qual -, mais importante que o nome que se dá a ação, é o pedido nele veiculado, em observância ao brocardo mihi factum dabu tibi ius. ${ }^{, 52}$

A quinta característica a ser citada é o fumus boni iruris. Segundo a doutrina, o fumus boni iuris é a plausibilidade da existência do direito alegado.

Por oportuno, transcreve-se a lição de Calamandrei:

A cognição cautelar se limita em cada caso a um juízo de probabilidade e de verossimilhança. Declarar a existência do direito era uma função do processo principal: em sede cautelar, bastava que a existência do direito parecesse verossímil, ou seja, melhor dizendo, bastava que, segundo cálculo de

\footnotetext{
${ }^{51}$ ASSIS, Araken de. Fungibilidade das medidas inominadas. [S.1.: s.n]. p. 49-51.

${ }^{52}$ MEDINA, José Miguel Garcia; ARAÚJO, Fábio Caldas de; GAJARDONI, Fernando da Fonseca. Procedimentos cautelares e especiais: ações coletivas, ações constitucionais, jurisdição voluntária, antecipação dos efeitos da tutela, Juizados Especiais Cíveis, Federais e da Fazenda Pública. [S.l: s.n.], 2010. p. 80.
} 
probabilidade, se previsse que o procedimento principal declararia o direito em sentido favorável àquele que tivesse requerido a medida cautelar. ${ }^{53}$

A sexta característica é Periculum in mora. Trata-se do risco de lesão ou mesmo de perecimento do direito se não houver pronta atuação do Estado-juiz.

Nessa perspectiva, deve haver risco de ineficácia do provimento definitivo a respeito do direito material, causando à parte uma lesão irreversível ou de difícil reparação, a justificar a necessidade de uma tutela que impeça ou neutralize o potencial dano. Portanto, o elemento dano está implícito no conceito de periculum in mora analisado sob à ótica da tutela cautelar.

Além disso, o dano deve ser grave e ao mesmo tempo irreparável ou de difícil reparação, devendo o juiz analisa-lo de forma objetiva a fim de formar o seu convencimento.

A doutrina adverte que o perigo de dano deve decorrer de uma situação posterior ao nascimento do próprio direito, ou ao menos deve ter havido um agravamento de um dano já existente.

Para Alexandre Freitas Câmara, "o risco a ser apurado será aquele irreversível ou de difícil reparação, hábil a fundar a aplicação da tutela cautelar, isto é, aquele que se consolidado, impede a efetividade prática da decisão de mérito." 54

Pulo Hoffman adverte que:

um processo adequado e justo deve demorar exatamente o tempo necessário para a sua finalização, respeitados o contraditório, a paridade entre as partes, o amplo direito de defesa, o tempo de maturação e compreensão do juiz, a realização de provas úteis e eventuais imprevistos, fato comum a toda atividade; qualquer processo que ultrapasse um dia dessa duração já terá sido moroso. ${ }^{55}$

\section{3}

\section{Características específicas da tutela antecipada de urgência}

O artigo 273, caput do CPC/73 exigia como pressuposto para a antecipação de tutela a "prova inequívoca que convença o juiz da verossimilhança da

\footnotetext{
${ }^{53}$ CALAMANDREI, op. cit., p. 99.

${ }^{54}$ CÂMARA, Alexandre Freitas. Lições de direito processual civil. 1. ed. Rio de Janeiro: Lumen Juris. v. 3, p. 33.

${ }^{55}$ HOFFMAN, Paulo. Razoável duração do processo. São Paulo: Quartier Latin, 2006. p. 61-62.
} 
alegação". A doutrina se manifestava no sentido de que a prova inequívoca significaria prova robusta, convincente e não aquela indiscutível, com valor absoluto.

Cassio Scarpinella Bueno salienta que o adjetivo "inequívoca”, portanto, relaciona-se com o substantivo prova; a verossimilhança é da alegação. É a prova inequívoca (prova contundente, prova bastante, prova forte, prova muito convincente por si só, independente da apresentação de outras), e como toda e qualquer prova, ela nada mais é do que um meio para convencer o magistrado de $\operatorname{algo}^{56}$.

Quanto à verossimilhança, sustentava-se a ideia de aparência de verdade, encerrando um juízo de probabilidade do direito pretendido.

Para José Miguel Garcia Medina,

a prova inequívoca consiste na representação cabal da situação narrada, seja através de documentos, seja através de outro meio de prova idôneo. Já a verossimilhança da alegação decorre da grande probabilidade de que o direito reclamado esteja mesmo a favorecer o postulante da medida antecipada. ${ }^{57}$

A doutrina majoritária baseava-se no argumento de que para a concessão da tutela cautelar, a cognição deveria ser realizada apenas para verificar a plausibilidade e o risco da demora. Por sua vez, na antecipação de tutela, o juízo de probabilidade era realizado com o fim de se entregar desde logo o bem da vida pretendido pelo autor.

O CPC/15 pretendeu acabar com essa distinção. Nos termos do artigo 300 do $\mathrm{CPC} / 15$, a tutela de urgência será concedida quando houver elementos que evidenciem a probabilidade do direito e o perigo de dano ou risco ao resultado útil do processo. Assim, sob a ótica do Novo CPC, a tutela de urgência pode ser de natureza cautelar ou satisfativa e, para a concessão dessas, exigem-se os mesmos requisitos, quais sejam, fumus boni iuris e periculum in mora. Pelo novo CPC, portanto, não há nenhuma diferença quanto aos requisitos, para a concessão da tutela antecipada e para a tutela cautelar em caráter de urgência.

\footnotetext{
${ }^{56}$ BUENO, C. S., op. cit., p. 13.

${ }^{57}$ MEDINA, J. M.; ARAUUJO; GAJARDONI, F. da F., op. cit. p. 48.
} 


\section{7}

\section{Tutela provisória no CPC/2015}

\section{1}

\section{Conceito de tutela provisória adotado pelo $\mathrm{CPC} / 15$}

O Código de Processo Civil de 2015 adotou a expressão tutela provisória para se referir à tutela antecipada e à tutela cautelar, seja fundamentada na urgência seja, na evidência.

O projeto do Senado Federal, na esteira do Anteprojeto, propunha a denominação "tutela de urgência e tutela de evidência". O projeto da Câmara do Deputados propôs, em seu lugar chama-la genericamente de "tutela antecipada", independentemente da natureza satisfativa ou cautelar da medida. Na última etapa do processo legislativo, o Senado modificou mais uma vez a denominação, para adotar o termo tutela provisória, ora empregado pelo Novo Código de Processo Civil.

Parte da doutrina critica a expressão tutela provisória adotada pelo novo CPC, argumentando sua imprecisão terminológica, uma vez que esta não delimita adequadamente o objeto de que trata o Livro $\mathrm{V}$, pois há regras que disciplinam a tutela de urgência cautelar, tutela de urgência satisfativa e tutela de evidência.

Conforme ensina Robson Renault Godinho, "o novo CPC reserva a expressão tutela provisória para disciplinar a tutela jurisdicional cautelar, a técnica da antecipação da tutela e a tutela da evidência, o que segundo ele já demonstra por si só infelicidade da denominação genérica." 58

Esclarecida a nomenclatura, devemos salientar que o CPC/15 consolida uma evolução da tutela provisória no direito brasileiro, procurando-lhe dar tratamento mais sistemático, de modo que fiquem expressas as disposições que lhe são comuns e as que são exclusivas de uma ou de outra espécie e, para isso,

\footnotetext{
${ }^{58}$ GODINHO, Robson Renault. Comentários ao artigo 294. In: CABRAL, Antonio do Passo; CRAMER, Ronaldo (Coords). Comentários ao novo Código de Processo Civil. Rio de Janeiro: Fornese, 2015. n. 2, p. 462.
} 
subdividiu-as, através do critério funcional, em cautelares e antecipadas, e, pelo critério da natureza, em tutela de urgência e de evidência.

A tutela provisória de urgência está preconizada nos artigos 294 a 310 do CPC, dividindo-se em tutela antecipada e cautelar, enquanto a tutela de evidência foi prevista num único dispositivo legal, qual seja, o artigo 311.

O artigo 294 do CPC/15 inaugura o regime jurídico da tutela provisória, preconizando no caput que o gênero tutela provisória pode fundamentar-se em urgência e evidência.

In verbis: “Art. 294. A tutela provisória pode fundamentar-se em urgência ou evidência."

Apesar de ambas serem provisórias, no entanto, não se confundem. O CPC/15 não define expressamente a tutela de urgência cautelar, antecipada e de evidência. Por isso, essas noções são extraídas da doutrina e da jurisprudência.

A tutela de urgência está precipuamente voltada a afastar o periculum in mora, servindo, portanto, para evitar um prejuízo grave ou irreparável enquanto o processo está em curso, ou seja, tem por escopo evitar o agravamento do dano ou a frustração integral da provável decisão favorável, já a tutela de evidência baseiase exclusivamente no alto grau de probabilidade do direito invocado, concedendo, desde já, aquilo que muito provavelmente virá ao final.

O parágrafo único do artigo 294, trata somente da tutela de urgência, preconizando que esta poderá ser cautelar ou antecipada, trançando a mesma regra geral para ambas, isto é, estabelece que ambas podem ser concedidas em caráter antecedente ou incidental. Esse dispositivo, portanto, deixa claro que o CPC/15 quis adotar um único regime jurídico para as tutelas de urgência.

Ambas são caracterizadas por uma cognição sumária, revogáveis e provisórias, que têm por escopo neutralizar os males do tempo do processo judicial, por meio de técnicas distintas, uma preservando (cautelar) e outra satisfazendo (tutela antecipada).

De acordo com Leonardo Greco;

A tutela antecipada corresponderia sempre a uma decisão interlocutória de acolhimento provisório, no todo ou em parte, do pedido formulado pelo autor, atendendo a requerimento expresso deste e tendo em vista acentuada probabilidade da sua procedência, à luz dos fundamentos e provas produzidos pelo requerente, acolhimento este que seria ratificado ou não na ulterior sentença final. Já a tutela cautelar constituiria uma providência de proteção do próprio processo, para 
assegurar a eficácia da decisão final sobre o direito material, mas não uma medida de acolhimento do pedido principal. A tutela cautelar pode ter por conteúdo uma providência instrutória do processo em curso ou uma medida assecuratória de bens ou de situações jurídicas para assegurar a eficácia da decisão final no processo principal, mas nunca tem o mesmo conteúdo do acolhimento do pedido principal, porque não se destina a antecipá-lo, mas a assegurar a eficácia. ${ }^{59}$

O artigo 295 do CPC/15 preconiza que a tutela de urgência ou de evidência, quando requerida em caráter incidental, independe do recolhimento de custas. Dessa forma, podemos vislumbrar um novo regramento dispensado à temática, pois a tutela provisória incidente não demanda ação autônoma, sendo requerida no bojo de um processo preexistente, por simples petição e independe do recolhimento de custas.

O artigo 296, caput, prevê que "a tutela provisória conserva sua eficácia na pendência do processo, mas pode, a qualquer tempo, ser revogada ou modificada". Isso se dá em razão de sua natureza jurídica, qual seja, a de decisão interlocutória, que se sujeita a recurso de agravo de instrumento, o qual, via de regra, não tem efeito suspensivo. Assim, mesmo com a interposição do agravo de instrumento, enquanto não houver a concessão do efeito suspensivo ou a sua revogação, a tutela provisória permanecerá produzindo efeitos.

No entanto, devemos salientar que se a tutela provisória for concedida na sentença, o recurso cabível será a apelação, que como regra geral, mantém o seu efeito suspensivo. Todavia, o artigo 1012, V do CPC/15 preconiza que o capítulo da sentença que diz respeito à tutela provisória, quando atacado por apelação, não estará sujeito ao efeito suspensivo, produzindo efeitos imediatos.

O parágrafo único do artigo 296 preconiza que, "salvo decisão judicial em contrário, a tutela provisória conservará a sua eficácia mesmo durante o período de suspensão do processo."

O artigo 297, caput, dispõe que "O juiz poderá determinar as medidas que considerar adequadas para efetivação da tutela provisória".

$\mathrm{O}$ referido dispositivo retrata o poder geral de cautela. Esse artigo tem por escopo conceder poderes ao juiz, para que este possa adotar a medida necessária a fim de garantir a tutela de urgência, analogamente ao que ocorria nos artigos $797 \mathrm{e}$ 798 do $\mathrm{CPC} / 73$, os quais preconizavam o poder geral de cautela. Uma vez que estes dispositivos da codificação anterior falavam em medidas assecuratórias, em

\footnotetext{
${ }^{59}$ GRECO, L., op. cit., p. 197.
} 
uma referência clara às cautelares, o que nos permitia falar em poder geral de cautela, o art. 297 do atual código, por falar em tutela provisória, também guardaria em si um poder análogo, porém de espectro maior, já que se refere as provisórias em geral.

Então com arrimo na norma legal citada, temos um poder geral de amplitude maior, que permitiria ao juiz agir também em situações onde a tutela de urgência em jogo tivesse natureza satisfativa e não cautelar.

Já o parágrafo único estabelece que "a efetivação da tutela provisória observará as normas referentes ao cumprimento provisório da sentença, no que couber". Tal dispositivo legal trata da execução da tutela provisória.

Leonardo Greco adverte que,

na tutela de urgência, cautelar ou antecipada, e na tutela de evidência, quando houver urgência, a efetivação da medida far-se-á pelo modo mais eficaz possível, independentemente das regras de execução ou de cumprimento provisório da sentença. Se for possível compatibilizar a urgência com o respeito às regras sobre cumprimento provisório da sentença, serão estas respeitadas. Caso elas se mostrem inadequadas, pelo risco de tornar ineficaz a tutela concedida, deverá o juiz adotar as providências mais adequadas. ${ }^{60}$

O artigo 298 preconiza que "na decisão que conceder, negar, modificar ou revogar a tutela provisória, o juiz motivará seu convencimento de modo claro e preciso". A decisão que conceder, negar, modificar ou revogar a tutela provisória deve ser fundamentada, nos termos do artigo $481 \S 1^{\circ}$ do CPC. Essas normas processuais visam concretizar o princípio da fundamentação das decisões judiciais uma garantia constitucional insculpida no artigo 93, IX, da CRFB/88, prevê que:

todos os julgamentos dos órgãos do poder judiciário serão públicos, e fundamentadas todas as decisões, sob pena de nulidade, podendo a lei, se o interesse público o exigir, limitar a presença, em determinados atos, às próprias partes e a seus advogados, ou somente a estes. ${ }^{61}$

Já o artigo 299 do CPC traz regramento acerca da competência do juízo que decidirá a tutela provisória. Estabelece o caput, que "a tutela provisória será requerida ao juízo da causa e, quando antecedente, ao juízo competente para conhecer do pedido principal."

\footnotetext{
${ }^{60}$ Ibidem, p. 206.

${ }^{61}$ Idem, nota n. 9.
} 
Pela leitura desse dispositivo legal, conjuntamente com o artigo $304 \S 4^{\circ}$, podemos perceber que o CPC/15 estabeleceu a prorrogação de competência do juízo da ação principal para a tutela provisória e a do juízo da tutela antecipada de urgência antecedente estabilizada para a ação de revogação.

E o parágrafo único do artigo 299, ressalvando alguma disposição em sentido contrário, atribui ao órgão do tribunal superior competente para apreciar o mérito, a competência para a tutela provisória nas ações de competência originária dos tribunais, nos recursos e na remessa necessária. Parte da doutrina entende que a ressalva se refere às suspensões de liminar e de segurança, da competência dos tribunais, mantidas pelo artigo 1059 do CPC/15.

\section{2}

\section{As disposições gerais do $\mathrm{CPC} / 15$ a respeito da tutela de urgência: artigos 300- 302}

O artigo 300 caput, do CPC/15, estabelece que "a tutela de urgência será concedida quando houver elementos que evidenciem a probabilidade do direito e o perigo de dano ou o risco ao resultado útil do processo."

Tutela de urgência em sentido amplo significa a concessão de medidas de urgência em favor do jurisdicionado.

Segundo José Roberto dos Santos Bedaque, a tutela de urgência se destina a englobar todas as medidas necessárias a fim de evitar o risco de dano ao direito.

Caracterizam-se não apenas pela sumariedade da cognição, circunstância também presente em tutelas não cautelares, mas pelo periculum in mora. Analisa-se a situação substancial e verifica-se a necessidade de proteção imediata, em sede cautelar, ante a impossibilidade de se aguardar o tempo necessário para a entrega da tutela final..$^{6}$

Podemos perceber, portanto, que o CPC/15 consagrou o entendimento de que para a concessão da tutela de urgência cautelar e satisfativa, exigem-se os mesmos requisitos, quais sejam, fumus boni iuris, que pode ser traduzido como probabilidade do direito e periculum in mora (perigo de dano ou risco ao resultado útil do processo), abandonando a diferenciação que o CPC/73 pretendia fazer entre os institutos.

\footnotetext{
${ }^{62}$ BEDAQUE, J. R. dos S., op. cit., p. 164.
} 
Note-se que a probabilidade do direito deve estar sempre presente, enquanto o perigo de dano ou o riso ao resultado útil do processo são requisitos alternativos, bastando a presença de apenas um deles para viabilizar a concessão da medida. Nesse aspecto, há na doutrina quem defenda a aplicação da "teoria da gangorra" para o fim de aferir os requisitos necessários para a concessão da tutela de urgência.

A teoria da gangorra preconiza que "quanto maior" o "periculum" demonstrado, menos "fumus" se exige para a concessão da tutela pretendida, pois a menos que se anteveja a completa inconsistência do direito alegado, o que importa para a sua concessão é a própria urgência, ou seja, a necessidade considerada em confronto com o perigo de demora na prestação jurisdicional. ${ }^{63}$

Sobre o tema, ensina Leonardo Ferres da Silva Ribeiro que a analogia à gangorra se justifica na medida em que:

numa das pontas, está o fumus boni iuris, na outra o periculum in mora. Quanto maior for o periculum, menos importância se dará ao fumus para a decisão acerca da concessão da tutela de urgência. É claro que precisa haver algum fumus, ou seja, algum grau de convencimento do juiz da possibilidade de, ao final, reconhecer o direito invocado. Ambos os requisitos devem estar presentes, mas os dois são variáveis ao sabor das particularidades do caso concreto. ${ }^{64}$

Portanto, entendemos que a convicção do juiz, diante do pedido de tutela de urgência, será determinada à luz do caso concreto, levando-se em consideração uma série de fatores, não só pela demonstração da plausibilidade do direito, mas principalmente pela intensidade do periculum in mora. Assim, feita a cognição sumária, e desde que o juiz vislumbre alguma possibilidade do direito invocado, deverá voltar-se para a intensidade do periculum in mora para decidir se concede ou não a tutela de urgência, pois como antes mencionado, quanto maior o periculum, maior a chance de deferimento.

Nos termos do $\S 1^{\circ}$ do artigo 300, "para a concessão da tutela de urgência, o juiz pode, conforme o caso, exigir caução real ou fidejussória idônea para

\footnotetext{
${ }^{63}$ WAMBIER, Teresa Arruda Alvim et al. Primeiros Comentários ao Novo Código de Processo Civil: artigo por artigo. 2. ed. rev. atual. e ampl. São Paulo: Revista dos Tribunais, 2016. p. 498 ${ }^{64}$ RIBEIRO, Leonardo Ferres da Silva. A "prova" exigida para a concessão da tutela de urgência: a demonstração, no plano processual, dos requisitos autorizadores para a concessão da tutela cautelar e da antecipação de tutela. Disponível em: <http: //www.silvaribeiro.com.br/ artigos/artigo3.pdf>. Acesso em: 26 dez. 2018.
} 
ressarcir os danos que a outra parte possa vir a sofrer, podendo a caução ser dispensada se a parte economicamente hipossuficiente não puder oferecê-la."

Essa caução tem natureza de contracautela, isto é, diante da cautela oferecida pelo autor, o sistema jurídico estabelece uma contracautela em favor do réu, visando assegurar-lhe o resultado útil diante de eventual responsabilização do autor pelos danos causados com a execução da tutela de urgência. No entanto, o referido dispositivo legal traz uma flexibilização dessa regra da caução, para os casos que envolver parte economicamente hipossuficiente. Caberá ao juiz, nessas hipóteses, verificar casuisticamente, se a caução deverá ou não ser imposta.

O $\S 2^{\circ}$ Do artigo 300 estabelece que "a tutela de urgência pode ser concedida liminarmente ou após justificação prévia."

Dessa forma, o juiz irá examinar a presença dos requisitos para a concessão da tutela de urgência e se não se convencer prima facie, deverá permitir à parte requerente que, em audiência de justificação prévia, traga elementos de prova a fim de demonstrar a plausibilidade de seu direito, bem como a presença do risco de dano ou ao resultado útil do processo.

O $\S 3^{\text {o }}$ do artigo 300 preconiza que "A tutela de urgência de natureza antecipada não será concedida quando houver perigo de irreversibilidade dos efeitos da decisão."

Apesar dessa previsão legal, a doutrina e a jurisprudência têm flexibilizado a aplicação dessa norma, deferindo a medida pleiteada, mesmo quando a situação se mostra irreversível. São situações em que os efeitos irreversíveis ocorrerão em qualquer hipótese concedendo-se ou não, a tutela de urgência. Nesses casos, caberá ao juiz fazer uma ponderação entre os riscos envolvidos, escolhendo aquele que entender causar o menor dos males.

O Artigo 301 do CPC/15 estabelece que "a tutela de urgência de natureza cautelar pode ser efetivada mediante arresto, sequestro, arrolamento de bens, registro de protesto contra alienação de bem e qualquer outra medida idônea para asseguração do direito."

Pela leitura do dispositivo legal, percebemos que as medidas cautelares inominadas passam a ser regra geral, e não apenas admitidas em caráter subsidiário das medidas cautelares típicas, como parecia pretender o legislador de 1973. 
Parte da doutrina entende que esse dispositivo legal, conjuntamente com o artigo 297 do CPC/15, retratam o poder geral de cautela. Isto porque, além de mencionar exemplos de medidas cautelares, ainda traz na parte final do seu caput a expressão "qualquer outra medida idônea para asseguração do direito", o que nos leva a entender que o juiz é dotado de poderes para eleger a medida cautelar que julgar mais adequada ao caso.

Por isso, podemos aduzir que o art. 301 ao não trazer um rol taxativo de possíveis medidas assecuratórias e trazer a possibilidade de adoção da medida mais adequada, na verdade apenas corrobora com a ideia de que ao juiz é lícito impor a medida cautelar que julgar mais adequada e necessária ao caso, otimizando, por conseguinte, a efetividade do provimento cautelar, no contexto da minimização dos danos às partes ou ao resultado útil do processo.

Por sua vez, o artigo 302 cuida da responsabilidade objetiva diante da tutela de urgência que venha a ser revogada.

Dispõe o referido dispositivo legal que:

Independentemente da reparação por dano processual, a parte responde pelo prejuízo que a efetivação da tutela de urgência causar à parte adversa, se:

I - a sentença lhe for desfavorável;

II - obtida liminarmente a tutela em caráter antecedente, não fornecer os meios necessários para a citação do requerido no prazo de 5 (cinco) dias;

III - ocorrer a cessação da eficácia da medida em qualquer hipótese legal;

IV - o juiz acolher a alegação de decadência ou prescrição da pretensão do autor.

Parágrafo único. A indenização será liquidada nos autos em que a medida tiver sido concedida, sempre que possível. ${ }^{65}$

Assim, o artigo 302 impõe a responsabilidade do requerente da tutela de urgência pelos danos que causar a efetivação da medida, caso a sentença final lhe seja desfavorável, se obtida em caráter antecedente, não tiver ele promovido a citação do requerido no prazo legal, se a medida caducar ou se o juiz acolher a alegação de decadência e prescrição.

Leonardo Greco adverte que,

a responsabilidade objetiva vulnera o acesso à justiça do requerente, preconizado no artigo $5^{\circ}, \mathrm{XXXV}$ da $\mathrm{CF} / 88$, criando obstáculo imensurável ao direito de ação. Com efeito, os riscos que o litigante de boa-fé enfrenta em decorrência do ingresso em juízo devem existir apenas no plano do direito processual, e hão de ser pré-

\footnotetext{
${ }^{65}$ Idem, nota n. 1.
} 
determinados e módico, limitando-se aos encargos da sucumbência, para que, devidamente sopesados pelo autor antes do ajuizamento da demanda, influam objetivamente na decisão de vir a juízo, refreando apenas o litigante temerário, e não criando efeito intimidativo excessivo em relação àquele que tem convicção de seu direito. Acresça-se que dos riscos da sucumbência, o autor necessitado pode livrar-se através do benefício da assistência judiciária gratuita. ${ }^{66}$

Assim, entendemos que somente se comprovada a litigância de má-fé (artigo 79 do CPC), incorrerá o requerente na responsabilidade preconizada no artigo 302 do CPC. Caso contrário, haveria injusto cerceamento de acesso à justiça, equiparando o comportamento lícito, pautado na boa-fé, ao comportamento ilícito, sujeitando àquele que exerceu direito constitucionalmente assegurado de acesso à justiça, ao risco de perda patrimonial de alcance imprevisível.

\footnotetext{
${ }^{66}$ GRECO, L., 2014; 2015, op. cit., p. 200.
} 


\section{8 \\ A tutela antecipada requerida em caráter antecedente e sua estabilização}

De acordo com o novo CPC, a tutela de urgência poderá ser cautelar ou satisfativa, concedida quaisquer delas, em caráter antecedente ou incidental.

Apesar de o CPC/15 reconhecer semelhanças entre as espécies de tutela de urgência, no entanto traçou procedimentos distintos para a tutela antecipada antecedente, prevista nos artigos 303 e 304 e para a tutela cautelar antecedente, disciplinada nos artigos 305 a 310, não tendo tratado especificamente do procedimento dessas tutelas quando requeridas incidentalmente.

$\mathrm{O}$ artigo 303 dispõe acerca do procedimento para requerimento de uma tutela antecipada em caráter antecedente.

Por força do caput do artigo 303 do CPC/15

nos casos em que a urgência for contemporânea à propositura da ação, a petição inicial pode limitar-se ao requerimento da tutela antecipada e à indicação do pedido de tutela final, com a exposição da lide, do direito que se busca realizar e do perigo de dano ou do risco ao resultado útil do processo. ${ }^{67}$

Alexandre Freitas Câmara adverte:

O procedimento previsto nos arts. 303 e 304 será empregado apenas naqueles casos em que a urgência for contemporânea à propositura da ação, hipótese em que, havendo urgência extrema, poderá o demandante limitar-se a, na petição inicial, requerer a tutela de urgência satisfativa, com a indicação do pedido de tutela final, a exposição sumária da causa, do direito que se busca realizar e da situação de perigo de dano iminente (303) além do valor da causa (art. $303 \S_{4^{\circ}}^{\circ}$ ). (...)Seria um rematado absurdo exigir do demandante e do seu advogado a elaboração de uma petição inicial completa, formalmente perfeita, que preenchesse todos os requisitos impostos por lei, pois é fundamental que a lei processual admita, em casos assim, uma petição " incompleta", mas que se revele suficiente para permitir a apreciação do requerimento de tutela de urgência satisfativa. ${ }^{68}$

Permite-se, portanto, que o autor da demanda formule a petição inicial para requerer tão somente a antecipação da tutela, demonstrando o fumus boni iuris e o

\footnotetext{
${ }^{67}$ Idem, nota n. 1.

${ }^{68}$ CÂMARA, Alexandre Freitas. O novo processo civil brasileiro. São Paulo: Atlas, 2016. p. 162.
} 
periculum in mora e, uma vez deferida a tutela pretendida, abrir-se-á a possibilidade de aditá-la, a fim de cumprir todas as exigências legais.

Através da petição inicial, o autor deverá indicar, desde já, o contorno do pedido principal, a fim de que se possa avaliar a extensão e os efeitos da providência de urgência pleiteada.

Nos termos do $\S 4^{\circ}$ "Na petição inicial a que se refere o caput deste artigo, o autor terá de indicar o valor da causa, que deve levar em consideração o pedido de tutela final."

Para não haver dúvida, o autor deverá observar o § 5ำ que estabelece que "O autor indicará na petição inicial, ainda, que pretende valer-se do benefício previsto no caput deste artigo."

É necessário que haja manifestação do autor pela opção desse procedimento.

Vale mencionar o entendimento de Cassio Scarpinella Bueno, para quem, além da exigência de que o autor formule opção expressa pelo procedimento, o mandado de citação e intimação do réu deve conter expressamente a advertência de que sua inércia acarretará a estabilização da tutela contra si, sob pena de vulnerar o contraditório e a ampla defesa.

(...) é certo que o prazo para que o réu interponha agravo de instrumento da decisão concessiva da tutela antecipada fluirá de sua intimação (art. 231). É fundamental ter certeza quanto a isto porque o silêncio do réu tem tudo para ser interpretado, com fundamento no caput do art. 304, como fator suficiente para estabilizar a tutela antecipada. Tão fundamental que o mandado de citação e intimação do réu deve conter esta consequência de maneira expressa, sob pena de comprometer os princípios do contraditório e da ampla defesa. Trata-se, ademais, de decorrência necessária, no plano infraconstitucional, do disposto nos arts. $5^{\circ}, 6^{\circ}, 9^{\circ}$ e $10 .^{69}$

Assim, o autor deverá fazer menção expressa na petição inicial de que, em razão da situação de urgência, formulará tão somente pedido de antecipação de tutela, de forma que uma vez concedida à tutela provisória pretendida, a petição será aditada nos termos do $\S 1^{\circ}$.

Uma vez concedida à tutela antecipada, o autor deverá aditar a petição inicial formulada nos termos do caput. Nesse aditamento, caberá a ele complementar sua argumentação, juntando novos documentos quando entender cabíveis, confirmando o pedido de tutela final, no prazo de 15 dias, ou outro prazo maior que o juiz entenda por bem fixar. $(303, \S 1$, I)

\footnotetext{
${ }^{69}$ BUENO, C. S., op. cit., p. 231
} 
Esclarece o $\S 3^{\circ}$ que: "o aditamento a que se refere o inciso I do $\S 1^{\circ}$ deste artigo dar-se-á nos mesmos autos, sem incidência de novas custas processuais."

Por força do inciso II do $\S 1^{\circ}$ do artigo 303 , tendo sido concedida a tutela antecipada, o réu será citado e intimado para a audiência de conciliação ou de mediação na forma do art. 334; e o inciso II complementa preconizando que, "em não havendo autocomposição, o prazo para contestação será contado na forma do art. 335."

Deferida a antecipação de tutela e não havendo o aditamento pelo autor, o processo será extinto sem resolução de mérito, nos termos do $\S 2^{\circ}$ que dispõe que: "Não realizado o aditamento a que se refere o inciso I do $\S 1$ o deste artigo, o processo será extinto sem resolução do mérito."

A petição inicial que veicula o pedido de tutela antecipada também está sujeita à emenda. Estabelece o $\S 6^{\circ}$ que "Caso entenda que não há elementos para a concessão de tutela antecipada, o órgão jurisdicional determinará a emenda da petição inicial em até 5 (cinco) dias, sob pena de ser indeferida e de o processo ser extinto sem resolução de mérito."

Cassio Scarpinella Bueno contando o referido $\S 6^{\circ}$ afirma:

Pergunto-me, prezado leitor, no que consiste a determinação de emenda à inicial regrada pelo dispositivo aqui analisado: trata-se de instigar o autor a trazer, ao conhecimento do magistrado, outros elementos conducentes à concessão da tutela antecipada (antecedente) ou, muito diferentemente, de determinar ao autor que deixe o pedido de tutela antecipada (antecedente) de lado e que, desde já, formule o "pedido de tutela final", nos moldes do inciso I do $\S 1^{\circ}$ do art. 303. Não vejo como recusar aprioristicamente a juridicidade das duas alternativas. Justamente por isso, entendo que cabe ao magistrado, por força do precitado art. 321, esclarecer no que consiste precisamente a emenda da inicial por ele pretendida, justificando o seu entendimento: trata-se de "reforçar" o pedido de tutela antecipada antecedente, visando, até mesmo, a sua estabilização, nos termos do art. 304 ou, diferentemente, trata-se de deixar de lado aquele pedido antecedente, em prol da tutela "final", hipótese em que, isso é irrecusável, poderá o autor formular incidentalmente pedido de tutela antecipada. ${ }^{70}$

Determinada a emenda, se o autor permanecer silente, a consequência será o indeferimento da petição inicial e a extinção do processo sem resolução de mérito.

Esclarecida a questão do procedimento da tutela antecipada requerida em caráter antecedente, passamos a analisar o artigo 304 do CPC/15 que trata da possibilidade de estabilização da tutela antecipada.

\footnotetext{
${ }^{70}$ Idem, p. 231-232.
} 


\section{1 \\ Estabilização da tutela antecipada em caráter antecedente}

Antes mesmo de iniciar a análise dessa novidade trazida pelo novo CPC, não podemos deixar de mencionar que tal instituto gera acirradas divergências, havendo, portanto, uma série de interpretações acerca desses dispositivos legais que ora serão enfrentados.

A ideia da estabilização é a de que a decisão proferida em sede de antecipação de tutela, no âmbito do procedimento antecedente, produza e mantenha os seus efeitos, independentemente da continuidade do processo de cognição plena e exauriente, uma vez que as partes se conformam com tal decisão.

Importante ressaltar que a possibilidade de estabilização de medidas de urgência, sem obrigatoriedade de ajuizamento de uma ação principal para aprofundamento da cognição, não representa algo absolutamente novo e desconhecido pela doutrina pátria ou sem qualquer previsão no direito estrangeiro.

Cândido Rangel Dinamarco, por exemplo, já defendia a possibilidade de estabilização da tutela antecipada em caráter antecedente, mesmo à luz do art. 273, I, do CPC/73: “(...) negar sistematicamente a tutela antecipada em caráter antecedente, ou preparatório, é ignorar o art. $8^{\circ}$ do Pacto de San José da Costa Rica, portador da severa recomendação de uma tutela jurisdicional dentro do prazo razoável". ${ }^{71}$

A esse respeito, afirma Heitor Vitor Mendonça Sica acerca da estabilização prevista no art. 304 do $\mathrm{CPC} / 15$ :

Trata-se de técnica inspirada em dispositivos presentes nos ordenamentos processuais estrangeiros - em especial do francês e do italiano - e que vem há tempos sendo debatida pela doutrina brasileira, bem como cogitada em outros anteprojetos ou projetos de lei que não vingaram [cita-se o anteprojeto encaminhado ao Senado, que discutiu a partir de 2005 o PLS n. 186/2005 e o arquivou em 2007]. ${ }^{72}$

\footnotetext{
${ }^{71}$ DINAMARCO, Cândido Rangel. Nova era do processo civil. São Paulo: Malheiros, 2003. p. 74.

72 SICA, Heitor Vitor Mendonça. Doze problemas e onze soluções quanto à chamada "estabilização" da tutela antecipada. In: COSTA, Eduardo José da Fonseca; DIDIER JR., Fredie; GOUVEIA FILHO, Roberto P. Campos; PEREIRA, Mateus Costa. (Orgs.). Coleção grandes temas do novo CPC: tutela provisória. Salvador: JusPodivm, 2016. v. 6, p. 346.
} 
A regra preconizada no artigo 304 do CPC tem por escopo, por um lado, eliminar a necessidade de discussão de uma questão que, diante da conduta do réu, não gera mais controvérsia e, de outro, outorgar capacidade de produzir efeitos a uma decisão interna a um processo extinto sem resolução do mérito. A estabilização visa otimizar a prestação jurisdicional, quando presente o desinteresse do demandado, representando, assim, a manutenção dos efeitos da tutela. Trata-se da generalização da técnica monitória, com a sua introdução ao procedimento comum, para além da previsão restrita a procedimentos especiais.

Segundo Fredie Didier, Paula Sarno e Rafael Alexandria;

A estabilização da tutela antecipada representa uma generalização da técnica monitória para situações de urgência e para a tutela satisfativa, na medida em que viabiliza a obtenção de resultados práticos a partir da inércia do réu. (...) Sucede que ao mesmo tempo em que mantém e amplia a ação monitória, o legislador vai além e generaliza a técnica monitória, introduzindo no procedimento comum para todos os direitos prováveis e em perigo que tenham sido objeto de tutela satisfativa provisória antecedente. O modelo da ação monitória (arts. 700 - 702 do CPC) deve ser considerado o geral- é, possível, inclusive pensar em um microssistema de técnica monitória, formado pelas regras da ação monitória e pelos arts. 303 a 304 do CPC, cujos dispositivos se complementam reciprocamente. ${ }^{73}$

Assim, tal como observam Humberto Theodoro Júnior e Érico Andrade, a tutela sumária passa a constituir uma alternativa para solução mais célere dos conflitos de direito material:

A tutela sumária sai da sua condição de mera suplência da tutela de cognição plena e ganha o palco da justiça civil e passa a constituir autonomamente, ao lado dos processos de cognição plena, uma alternativa autônoma para a solução mais célere das crises de direito material, sem, contudo, eliminar-se ou suprimir-se a possibilidade de escolha da via de cognição plena. ${ }^{74}$

Convém salientar que apesar dessa possibilidade de encerramento do processo através da técnica da estabilização da tutela de urgência, nada obsta à parte, de instaurar processo para o fim de ser proferida sentença de mérito após o exercício da cognição plena, com amplo contraditório, em consonância com o devido processo legal.

Nesse diapasão, afirma Alex Costa Pereira,

\footnotetext{
${ }^{73}$ DIDIER JUNIOR, Fredie; BRAGA, Paula Sarno; OLIVEIRA, Rafael Alexandria de. Curso de direito processual civil. 10. ed. Salvador: JusPodivm,2015, v. 2, p. 604-605.

${ }^{74}$ THEODORO JR, H., op. cit. 2012. p. 23.
} 
(...) tendo em vista a inafastabilidade desses elementos informadores do devido processo legal moldado pela Constituição Federal (garantias do contraditório e da ampla defesa), a luz que se enxerga para a harmonização do sistema (...) advém de consistente indício de que a garantia da cognição plena não se mostra respeitada apenas na hipótese de desenvolvimento e exercício efetivo, no plano fático, da ampla defesa e do contraditório pelos sujeitos parciais do processo, mas também na hipótese de o sistema processual assegurar àquele contra o qual foi proferida a decisão em cognição sumária a opção pela instauração da atividade cognitiva completa. $^{75}$

Entendemos que técnica da estabilização da tutela antecipada é resultado de uma ponderação de interesses, donde a segurança jurídica e o contraditório acabam por ceder em algumas hipóteses, à necessidade de uma tutela jurisdicional mais efetiva e tempestiva.

Estabelece o art. 304do CPC que "A tutela antecipada, concedida nos termos do art. 303, torna-se estável se da decisão que a conceder não for interposto o respectivo recurso."

Convém ressaltar que apesar de o dispositivo legal preconizar o cabimento da técnica da estabilização de tutela apenas no caso de tutela antecipada antecedente, parte da doutrina defende que a melhor interpretação seria conferir um interpretação extensiva ao dispositivo legal, devendo-se admitir a estabilização tanto no caso de tutela antecipada antecedente, como nos casos de tutela antecipada incidental e, também no caso de tutela de evidência.

Nesse sentido, asservera Leonardo Ferres da Silva Ribeiro:

A melhor interpretação, segundo pensamos, é aquela que confere a maior eficácia possível ao instituto, admitindo-se, assim, a estabilização mesmo no caso da tutela antecipada deferida incidentalmente, desde que requerida (e concedida) liminarmente. $\mathrm{O}$ que não faz sentido é permitir a estabilização quando a tutela antecipada é deferida após o exercício do contraditório e tendo prosseguido o processo. Ainda nesse contexto, deve-se admitir a estabilização da tutela de evidência (que é antecipada), desde que, obviamente, tenha sido deferida liminarmente. Na tutela de evidência, em razão da grande probabilidade do direito em favor do autor, também deve ser permitida a técnica da estabilização, evitandose com isso o prosseguimento do processo, caso não haja um recurso contra a decisão que a concede. ${ }^{76}$

\footnotetext{
${ }^{75}$ PEREIRA, Alex Costa. Tutela sumária - A estabilização da tutela antecipada e sua adequação ao modelo constitucional do processo civil brasileiro. 2012. Tese (Doutorado em Direito). Programa de Pós-Graduação em Direito, Faculdade de Direito, Universidade de São Paulo, São Paulo, 2012. Disponível em: <http://www.teses.usp.br/teses/disponiveis/2/2137/tde26032013103821/ publico/ ALEX_COSTA_PEREIRA_Resumo.pdf >. Acesso em: 7 jan. 2019. p. 9-10.

76 RIBEIRO, Leonardo Ferres da Silva. Tutela provisória. In: TALAMINI, Eduardo; WAMBIER, Teresa Arruda Alvim. (Orgs.). Temas essenciais do novo CPC: Análise das
} 
Nesse mesmo sentido, defendendo uma intepretação sistemática do referido dispositivo legal, para o fim de permitir a adoção desta técnica em outras hipóteses, vale trazer o entendimento de Bruno Redondo Garcia, que afirma:

Consideramos que, com as necessárias adaptações procedimentais, é possível - de lege lata, em interpretação sistemática - a adoção da técnica da estabilização (com eventual extinção do processo) para a tutela antecipada incidental e a formulação de requerimento antecedente de tutela da evidência, com possibilidade de estabilização de efeitos e extinção da demanda. ${ }^{77}$

No entanto, há quem faça uma interpretação literal do artigo 304 do CPC, entendendo que a estabilização da tutela se aplicaria apenas à tutela antecipada antecedente. Nesse diapasão, assevera Luiz Guilherme Marinoni, Sérgio Cruz Arenhart e Daniel Mitidieiro:

Apenas a tutela provisória satisfativa fundada na urgência pode ser autonomizada e estabilizada. A tutela da evidência não pode ser autonomizada e, por conseguinte, estabilizada. A tutela cautelar, embora possa ser autonomizada, não pode ser estabilizada - dada obviamente a referibilidade que lhe é inerente. ${ }^{78}$

Leonardo Carneiro da Cunha também se manifesta no sentido de conferir uma interpretação literal ao dispositivo legal, entendendo que não há estabilização da tutela provisória cautelar, nem da tutela de evidência, mas tão somente da tutela provisória de urgência satisfativa requerida em caráter antecedente.

Através de interpretação literal do dispositivo legal, o que propiciará a ocorrência, ou não da estabilização será a providência recursal.

Não havendo a interposição de recurso, o $§ 1^{\circ}$ dispõe que a decisão que antecipou a tutela tornar-se-á estável e o processo será extinto. Portanto, pela letra fria da lei, a ausência de recurso em face da decisão que antecipou a tutela, acarretará a sua estabilização e o processo, com ou sem contestação, será extinto.

Não nos parece ser essa a melhor interpretação. Em verdade, qualquer forma de inconformismo do réu deve ter o condão de evitar a extinção do processo.

principais alterações do sistema processual civil brasileiro. São Paulo: Revista dos Tribunais, 2016. p. 204.

77 REDONDO, Bruno Garcia. Estabilização, modificação e negociação da tutela de urgência antecipada antecedente: principais controvérsias. In: COSTA, Eduardo José da Fonseca; DIDIER JR., Fredie; GOUVEIA FILHO, Roberto P. Campos; PEREIRA, Mateus Costa. (Orgs.). Coleção grandes temas do novo CPC: tutela provisória. Salvador: JusPodivm, 2016. v. 6. p. 292.

${ }^{78}$ MARINONI, Luiz Guilherme; ARENHART, Sérgio Cruz; MITIDIEIRO, Daniel. Código de Processo Civil Comentado. 2. ed. São Paulo: Editora Revista dos Tribunais, 2016. p. 386. 
Segundo Luiz Guilherme Marinoni, a técnica da estabilização da tutela envolve uma questão fundamental, qual seja, a da generalização da premissa de que a inação do demandado configura desinteresse, porém não é possível admitir que a inércia do réu, em todo e qualquer caso concreto, configure desinteresse e, assim, possa ter o significado de aceitação da tutela antecipada. Dessa forma, não se deve partir da premissa de que o réu não interpôs agravo, por falta de interesse na discussão da questão.

Nas palavras do processualista,

Diante da generalização dos efeitos da não atuação do demandado, é preciso que qualquer forma de reação, ainda que não o agravo de instrumento, seja vista como sinal de inconformidade, capaz de determinar o prosseguimento do processo não apenas para a discussão do caso, mas para que o autor se desincumba do ônus de provar as alegações de fato que foram admitidas como prováveis. É certo que a contestação tem razão para ser apresentada antes do aditamento da petição inicial. Mas se o autor, ao receber a intimação de efetivação da tutela antecipada apresenta petição impugnando a forma concedida para a prestação da tutela ou a sua efetivação e, por lapso, perde o prazo do agravo de instrumento, há que se considerar a sua petição como inconformismo com a tutela antecipada. Imagine-se a hipótese de tutela inibitória antecipada, em que o juiz determina a paralização das atividades de uma indústria quando bastaria a instalação de determinada tecnologia. Se o réu imediatamente adverte o juiz de que a tutela concedida para impedir a poluição ambiental poderia e deveria ser prestada por um meio mais suave, ou seja, um meio que além de idôneo à tutela do direito, constitui menor restrição à sua esfera jurídica, há a alegação de violação à regra da proporcionalidade e manifestação de inconformismo com a tutela concedida - que, assim, não tem qualquer motivo para se estabilizar. ${ }^{79}$

Nesse mesmo sentido, admitindo não só o recurso, como também outras

formas de oposição para evitar a estabilização, cita-se Daniel Mitidieiro.

É claro que pode ocorrer de o réu não interpor o agravo de instrumento, mas desde logo oferecer contestação no mesmo prazo - ou, ainda, manifestar-se dentro desse mesmo prazo pela realização da audiência de conciliação ou de mediação. Nessa situação, tem-se que entender que a manifestação do réu no primeiro grau de jurisdição serve tanto quanto a interposição do recurso para evitar a estabilização dos efeitos da tutela. Essa solução tem a vantagem de economizar o recurso de agravo e de emprestar a devida relevância à manifestação de vontade constante da contestação ou o intento de comparecimento à audiência. Em ambas as manifestações, a vontade do réu é inequívoca no sentido de exaurir o debate com o prosseguimento do procedimento. ${ }^{80}$

\footnotetext{
${ }^{79}$ MARINONI, Luiz Guilherme. Estabilização da tutela. [S.1.]. Revista de processo, v. 279, p. 225-243, maio, 2018.

${ }^{80}$ MITIDIERO, Daniel. Autonomização e estabilização da antecipação de tutela no novo código de processo civil. Revista Magister de Direito Civil e Processual Civil, n. 63, nov./dez. 2014.
} 
Em sentido contrário, pela literalidade da norma, admitindo apenas o recurso de agravo de instrumento para impedir a estabilização, posicionam-se Dierle Nunes e Érico Andrade.

(...) em razão de que o legislador do NCPC adotou aqui, posição expressa no sentido de optar pelo recurso como meio para impedir a estabilização, considerando, inclusive, que nas versões anteriores do projeto se utilizava o termo mais abrangente" impugnação" e, afora, no projeto aprovado e que se transformou no NCPC houve uma tomada de posição quanto ao instrumento processual capaz de impedir a estabilização: o recurso. ${ }^{81}$

Assim, podemos concluir que a ausência de recurso ou impugnação (melhor dizendo a nosso ver) contra a decisão que antecipou a tutela satisfativa em favor do autor acarreta duas consequências, quais sejam, a estabilização e a extinção do processo.

Porém, estabelece o $\S 2^{\circ}$ do artigo 304 que "Qualquer das partes poderá demandar a outra com o intuito de rever, reformar ou invalidar a tutela antecipada estabilizada nos termos do caput".

Trata-se de outra ação, respaldada em cognição exauriente, ajuizada por aquele que visa discutir a antecipação de tutela. De qualquer forma, a tutela antecipada conservará seus efeitos enquanto não revista, reformada ou invalidada por decisão de mérito proferida na ação de que trata o $§ 2^{\circ}$. ( $§ 3^{\circ}$-do artigo 304)

Qualquer das partes poderá requerer o desarquivamento dos autos em que foi concedida a medida, para instruir a petição inicial da ação a que se refere o $\S$ $2^{\circ}$, prevento o juízo em que a tutela antecipada foi concedida. ( $\$ 4^{\circ}$ do artigo 304)

Por sua vez, preconiza o $§ 5^{\circ}$ que "O direito de rever, reformar ou invalidar a tutela antecipada, previsto no $\S 2^{\circ}$ deste artigo, extingue-se após 2 (dois) anos, contados da ciência da decisão que extinguiu o processo, nos termos do $§ 1$ o."

Trata-se de prazo decadencial e, por isso, não admite suspensão ou interrupção. Assim, podemos observar que o legislador introduziu um limite temporal para que as partes pudessem pleitear o desfazimento dessa decisão que estabilizou a antecipação de tutela. Após esse prazo, não é dado às partes, o direito de discutir tal decisão. Isto porque, a tutela antecipada estabilizada não é passível

\footnotetext{
${ }^{81}$ NUNES, Dierle; ANDRADE, Érico. Os contornos da estabilização da tutela provisória de urgência antecipatória no novo CPC e o mistério da ausência de formação da coisa julgada. MACÊDO, Lucas Buril de; PEIXOTO, Ravi; FREIRE, Alexandre (Coords.). Doutrina Selecionada: Procedimentos Especiais, Tutela Provisória e Direito Transitório. 2. ed. Salvador: Juspodivm, 2015, v. 4. p. 83-84.
} 
de ser impugnada por meio da ação rescisória, uma vez que tal decisão não faz coisa julgada material.

Nesse sentido, o enunciado 33 do Fórum Permanente de Processualistas Civis: "Não cabe ação rescisória nos casos de estabilização da tutela antecipada de urgência."

Assim, nessa hipótese, caberá uma ação perante o próprio juízo do processo originário destinada a rever, reformar ou invalidar a decisão concessiva da tutela de urgência, desde que observado o prazo máximo de dois anos, a contar da extinção do processo. Nessa demanda, o juiz irá aprofundar a cognição, que até então fora sumária. A doutrina entende que tanto o autor, quanto o réu, podem propor essa ação preconizada nos $\S \S 2^{\circ}$ e $5^{\circ}$ do art. 304 do CPC.

$\mathrm{O} \S 6^{0}$ estabelece que "A decisão que concede a tutela não fará coisa julgada, mas a estabilidade dos respectivos efeitos só será afastada por decisão que a revir, reformar ou invalidar, proferida em ação ajuizada por uma das partes, nos termos do $\S 2^{\circ}$ deste artigo.”

Vale ressaltar que a opção feita pelo legislador quanto à ausência de coisa julgada material teve inspiração no direito italiano e francês.

Quando o juiz defere a tutela provisória de urgência, restringe-se a reconhecer a presença de seus requisitos, quais sejam, a probabilidade do direito alegado e o perigo da demora. Não há, portanto, declaração do direito. Não há julgamento apto a formar coisa julgada, uma vez que o juiz não reconhece o direito do autor, com base num juízo de cognição exauriente. O magistrado, nessa hipótese, reconhecendo a presença dos requisitos para a concessão da tutela provisória, antecipa os efeitos mandamentais ou executivos, os quais, não havendo recurso do réu, tornar-se-ão estáveis. O que se percebe, portanto, é que há aí uma estabilidade diversa da coisa julgada e, nesse ponto, a estabilização da tutela de urgência diferencia-se da ação monitória, em cujo âmbito há, sim, formação da coisa julgada. Na ação monitória, expedido o mandado de pagamento ou cumprimento da obrigação, se o réu se mantiver inerte, aquela ordem de pagamento ou cumprimento da obrigação transformar-se-á em título executivo judicial, com a formação da coisa julgada. Por sua vez, a decisão concessiva da tutela de urgência, com a inércia do réu, tornar-se-á estável. 
Apesar da ausência de coisa julgada material, a doutrina majoritária entende que após o decurso do prazo de 2 anos, haveria impossibilidade de modificação da decisão estável.

Nesse sentido, Dierle Nunes e Érico Andrade entendem que o impedimento para a modificação desta decisão estabilizada não decorre da coisa julgada, que inexiste in casu, mas sim, dos institutos da prescrição e da decadência. ${ }^{82}$

Por sua vez, Bruno Garcia Redondo defende que há formação de coisa julgada material após os dois anos previstos no art. $304 \S 5^{\circ}$ do CPC.

Luiz Guilherme Marinoni, interpretando tal dispositivo legal, entende que não pode ter a estabilização de tutela, qualquer efeito preclusivo próprio da coisa julgada. Para ele, o direito afirmado provável ou a questão jurídica decidida com base em cognição sumária, podem voltar a ser discutidos pelo demandado em qualquer processo.

(....) existe o problema do significado do $\S 5^{\circ}$ do artigo 304 do CPC, ou mais precisamente, da extinção do direito de reformar ou invalidar a tutela antecipada. A impossibilidade de se pedir a revisão da decisão que concedeu a tutela antecipada para reforma-la ou invalidá-la nada tem a ver com a coisa julgada. Ora, se o legislador optou por não atribuir à decisão que concede a tutela que se estabiliza a qualidade de coisa julgada material, certamente em virtude da precariedade da cognição que está à sua base, não há razão para supor que o decurso do prazo para o exercício do direito de revê-la tenha força de conferir à decisão não revista a autoridade de coisa julgada material. (....) Não ter mais direito de reformar ou invalidar a tutela antecipada não significa não poder mais discutir o direito que foi suposto como provável para se conceder a tutela. Esse direito pode ser rediscutido em qualquer processo, desde que não para reformar ou invalidar a tutela antecipada. Assim, por exemplo, o réu pode rediscutir a ilicitude sumariamente afirmada para a concessão da tutela inibitória, não obstante esta tutela não possa mais ser confirmada ou invalidada. ${ }^{83}$

Bruno Garcia Redondo faz uma importante observação a respeito do cabimento, ou não, de honorários advocatícios quando da estabilização da tutela antecipada e, por consequência, da extinção do processo.

Fazendo uma interpretação sistemática e teleológica, defende a redução dos honorários pela metade, tal como previsto pelo próprio $\mathrm{CPC} / 15$ para outras hipóteses em que o réu não opõe resistência. Assim, segundo o autor, se o réu não oferecer resistência à concessão da tutela antecipada antecedente, gerando a estabilização da tutela e a extinção do processo, a sentença que extingue o

\footnotetext{
${ }^{82}$ Ibidem, p. 89-90.

${ }^{83}$ MARINONI, L.G., op. cit., p. 225-243.
} 
processo ( $§ 1^{0}$ do art. 304) deve condenar o réu em honorários advocatícios correspondente à metade do mínimo $(10 \%)$, isto é, cinco por cento. ${ }^{84}$

\section{2}

\section{Limites à estabilização da tutela antecipada antecedente}

Bruno Garcia Redondo aponta alguns limites à estabilização da tutela antecipada, apesar de a lei processual ser omissa nesse sentido.

Assevera o jurista:

Importante destacar, de início, situações em que é descabida a concessão de tutela antecipada de forma antecedente e/ou a sua estabilização: (i) quando o réu for citado por edital ou com hora certa, se for incapaz sem representante legal (ou com interesses colidentes) ou se estiver preso; (ii) quando se tratar de direito indisponível ou for o caso de situação em que, ainda que inexistisse contestação, ficaria impedida a produção do efeito material da revelia; e (iii) quando o pedido antecedente referir-se a tutela declaratória ou constitutiva, para as quais entende-se, majoritariamente, que não cabe a técnica da antecipação de efeitos. ${ }^{85}$

\footnotetext{
${ }^{84}$ REDONDO, Bruno. Estabilização, modificação e negociação da tutela de urgência antecipada antecedente: principais controvérsias. Revista de Processo, v. 244, junho, 2015. p. 167-194.

${ }^{85}$ Ibidem, 2016, p. 284-285.
} 


\section{9}

\section{A tutela cautelar requerida em caráter antecedente no novo CPC: arts 305 a 310}

Os arts 305- 310 do CPC/15 disciplinam a tutela cautelar requerida em caráter antecedente.

Preconiza o artigo 305 que " a petição inicial da ação que visa à prestação de tutela cautelar em caráter antecedente indicará a lide e seu fundamento, a exposição sumária do direito que se objetiva assegurar e o perigo de dano ou o risco ao resultado útil do processo."

Já o parágrafo único do artigo 305 estabelece que "Caso entenda que o pedido a que se refere o caput tem natureza antecipada, o juiz observará o disposto no art. 303.” Trata-se de aplicação do princípio da fungilibidade.

No campo da tutela de urgência no atual sistema, o princípio da fungibilidade sofreu uma profunda transformação, de modo que podemos afirmar que este princípio foi incorporado ao ordenamento jurídico pátrio, devendo lhe ser dada uma interpretação ampliativa.

$\mathrm{O}$ atual sistema supera as antigas divergências a respeito de seu cabimento, em se tratando das diversas espécies de tutelas de urgência, de especificidades procedimentais, avançando no sentido de autorizar a concessão das medidas de urgência pelo juiz ao mesmo tempo que determina a adaptação do procedimento.

Com a unificação das categorias de tutela de urgência pelos seus requisitos, bem como pela aproximação de seus procedimentos antecedentes, a fungibilidade foi ampliada a fim de sempre determinar o aproveitamento do ato pela adaptação do procedimento.

Conforme se observa pela leitura do referido parágrafo único do artigo 305 do CPC, sendo proposta a ação inicialmente cautelar e verificando o juiz tratar-se de pedido satisfativo, deve adaptar o procedimento e prosseguir nos termos previstos no art. 303 para a concessão da antecipação dos efeitos da sentença. Logo, por expressa previsão legal, não deve haver a extinção por razões procedimentais, uma vez que o juiz deve oferecer tutela protetiva contra o risco. 
O mesmo ocorre em sentido inverso, ou seja, se o pedido for formulado em termos de antecipação da tutela, mas se verificar que sua natureza é cautelar, o juiz deverá conceder a medida e ajustar o procedimento ao rito das tutelas cautelares.

Logo, há plena fungibilidade procedimental entre os ritos das tutelas de urgência antecedentes. No que diz respeito a concessão de providências cautelares, a extinção de cautelares típicas ampliou o sentido de fungibilidade ao permitir a variabilidade judicial conforme a necessidade instrutória ou conservativa demonstrada, reforçando o entendimento já consolidado de que as cautelares são comprometidas com a dignidade de jurisdição e, por isso mesmo, sob ampla variabilidade judicial. ${ }^{86}$

Nas palavras de Leonardo Greco:

Na tutela cautelar, como na execução, a adstrição se limita ao pedido mediato, ou seja, ao bem da vida, ao interesse que o autor pretende proteger, ao objeto da tutela, não ao meio de proteção, à providência jurisdicional requerida para alcança-la. (....) o legislador de 2015, mais claro e categórico do que o de 1973, não adotou redação que pudesse comportar interpretação restritiva da fungibilidade apenas a momento ulterior, à substituição da tutela anteriormente concedida. Tampouco reproduz a exigência expressa de que a concessão de medida cautelar diversa da que foi requerida seja condicionada à menor onerosidade para o requerido. $\mathrm{O}$ juízo de ponderação entre o perigo que assola o requerente e o que poderá incidir sobre o requerido caso a tutela cautelar seja deferida, deverá ser sempre efetuado pelo juiz, não só para decidir se concede ou não a providência pretendida, mas também para efetuar a escolha mais adequada e proporcional. ${ }^{87}$

Para Leonardo Greco, o novo dispositivo tem alcance diverso, conforme se trate de tutela cautelar ou antecipada.

Adverte o processualista;

Parece-me, pois, que na tutela antecipatória, a única interpretação razoável do artigo 297 é a de que o dispositivo não faculta a concessão de providência jurisdicional diversa, mas que, na efetivação ou cumprimento da decisão, tal como na tutela específica do $\mathrm{CPC} / 73$, o juiz possa aí sim, pela sua natureza substancialmente executória, fazer uso de meios coativos ou sub-rogatórios que the pareçam mais adequados e eficazes. ${ }^{88}$

Portanto, no tocante à tutela antecipada, de urgência ou de evidência, Leonardo Greco entende que a adstrição é mais rigorosa, pois segundo ele aqui se

\footnotetext{
${ }^{86}$ NOGUEIRA JÚNIOR, Alberto. Medidas Cautelares Inominadas Satisfativas ou Justiça Cautelar. São Paulo: LRT. 1999. p. 123.

${ }^{87}$ GRECO, L., op. cit., p. 194-195.

${ }^{88}$ Idem.
} 
trata de apreciação de pedido sobre a atribuição ao requerente, ainda que provisória de providência do direito material, declaratória, constitutiva ou condenatória. Aqui o juiz não pode conceder providência diversa da requerida, sob pena de violação ao princípio da demanda e de prolação de julgamento extra petita.

Para Leonardo Greco é possível haver fungibilidade entre a tutela de urgência e a tutela de evidência, desde que o pedido formulado inicialmente preencha os requisitos da tutela a ser concedida.

Assim, podemos concluir que no que toca à tutela antecipada, de natureza satisfativa, o cenário é distinto. Nesse caso, o juiz não pode deferir providência diversa da pretendida pela parte, uma vez que nesse caso, há inegável feição meritória. O regime legal em nada alterou o princípio dispositivo e da demanda, de modo que as providências não podem ser entregues de ofício, como não é possível a incidência da fungibilidade para alterar postulação específica.

Nesse sentido, o STJ já entendeu que a tutela antecipada está adstrita ao pedido decorrente do direito material que foi invocado e propugnado na demanda, à medida que somente os efeitos derivados da decisão final podem ser antecipados. (AGA 208757/RS)

$\mathrm{O}$ artigo 306 do $\mathrm{CPC} / 15$ dispõe que "O réu será citado para, no prazo de 5 (cinco) dias, contestar o pedido e indicar as provas que pretende produzir."

Há que ressaltar que a contestação a que se refere esse dispositivo legal está circunscrita à petição que veicula o pedido de tutela cautelar e não o pedido principal, que somente será deduzido posteriormente, nos termos do artigo 308 do CPC.

Já o artigo 307 preconiza que "Não sendo contestado o pedido, os fatos alegados pelo autor presumir-se-ão aceitos pelo réu como ocorridos, caso em que o juiz decidirá dentro de 5 (cinco) dias."

Portanto, o referido artigo traz as consequências jurídicas da falta de apresentação da contestação, ou seja, nesse caso aplicar-se-á o efeito da revelia, consistente na presunção de veracidade dos fatos alegados na petição inicial, devendo o juiz decidir em cinco dias.

Devemos salientar que a revelia não necessariamente conduzirá à procedência do pedido, pois o juiz somente proferirá decisão se convencido da presença dos requisitos legais para a sua concessão. Essa decisão tem natureza 
interlocutória, salvo nos casos em que o juiz reconhecer a prescrição ou decadência do direito do autor, sujeita, portanto, ao recurso do agravo de instrumento.

O parágrafo único do 307 estabelece que "Contestado o pedido no prazo legal, observar-se-á o procedimento comum.”

Por sua vez, o Art. 308 dispõe que "Efetivada a tutela cautelar, o pedido principal terá de ser formulado pelo autor no prazo de 30 (trinta) dias, caso em que será apresentado nos mesmos autos em que deduzido o pedido de tutela cautelar, não dependendo do adiantamento de novas custas processuais."

Assim, executada a medida cautelar, caberá ao autor deduzir o pedido principal no prazo de trinta dias, contados da efetivação da cautelar. Esse pedido não será deduzido por meio de ação autônoma, como ocorria sob à égide do $\mathrm{CPC} / 73$, mas sim por meio de petição apresentada nos mesmos autos em que deduzido o pedido de tutela cautelar, sem recolhimento de novas custas.

É facultado ao autor que veicule o pedido principal juntamente com o pedido de cautelar antecedente, evitando-se com isso, a necessidade de sua formulação posterior, conforme preconiza o $\S 1^{\circ}$ do 308 do CPC. No entanto, caso o autor opte por deduzir o pedido principal posteriormente, possibilita-se o aditamento da causa de pedir no momento da formulação do pedido principal ( $\left.308 \S 2^{\circ}\right)$

Dispõe o $308 \S 3^{\circ}$ que "Apresentado o pedido principal, as partes serão intimadas para a audiência de conciliação ou de mediação, na forma do art. 334, por seus advogados ou pessoalmente, sem necessidade de nova citação do réu."

Não havendo autocomposição, o prazo para contestação será contado na forma do art. 335. $\left(308 \S 4^{\circ}\right)$.

É de se registrar que diante da independência entre a tutela cautelar e a principal, o indeferimento da cautelar não obsta à apreciação do pedido principal, salvo se quando do julgamento da cautelar, o juiz reconhecer a ocorrência de prescrição ou decadência do direito do autor, nos termos do artigo 310 do CPC.

O artigo 309 do CPC elenca as hipóteses em que haverá a cessação da eficácia da tutela cautelar concedida em caráter antecedente. O inciso I preconiza a hipótese em que o autor deixa transcorrer in albis o prazo legal para deduzir o pedido principal. Nesse caso, haverá a extinção da eficácia da medida cautelar acaso concedida. 
O inciso II do 309 refere-se à hipótese em que a medida cautelar não é efetivada dentro de trinta dias. Devemos, no entanto, interpretar essa norma cum ganho salis, uma vez que o autor não pode ser prejudicado por fatos alheios à sua vontade.

O inciso III do artigo 309 dispõe que cessa a eficácia da tutela concedida em caráter antecedente, se o juiz julgar improcedente o pedido principal formulado pelo autor ou extinguir o processo sem resolução de mérito. Assim, caso o resultado seja o julgamento de improcedência do pedido final, ou mesmo a extinção do processo sem resolução de mérito, não se pode pensar em manutenção da tutela cautelar.

O parágrafo único do 309 prevê que "Se por qualquer motivo cessar a eficácia da tutela cautelar, é vedado à parte renovar o pedido, salvo sob novo fundamento.” Dessa forma, tendo a medida cautelar perdido a sua eficácia, não poderá à parte novamente deduzir o mesmo pedido, salvo se arguir nova causa de pedir, uma vez que não há se falar em coisa julgada material.

O último dispositivo relativo à tutela cautelar antecedente é o artigo 310 que preconiza que "O indeferimento da tutela cautelar não obsta a que a parte formule o pedido principal, nem influi no julgamento desse, salvo se o motivo do indeferimento for o reconhecimento de decadência ou de prescrição.”

Trata-se de dispositivo que reconhece a independência entre a tutela cautelar e a tutela satisfativa pleiteada no pedido principal. Isto porque, essas tutelas têm objetivos distintos, uma vez que enquanto a cautelar está limitada a assegurar a eficácia e a utilidade do resultado buscado na tutela principal, a tutela satisfativa realiza o direito material deduzido em juízo. Assim, a decisão relativa ao pedido cautelar, justamente em razão de ser fundamentada em cognição sumária, não faz coisa julgada, de forma que o seu resultado não pode influenciar no pedido principal. A exceção a essa regra se dá apenas quando, mesmo no pedido cautelar, há o reconhecimento da prescrição ou decadência do direito do autor, uma vez que nessa hipótese estaremos diante de uma decisão de mérito apta à formação da coisa julgada material. 
10

\section{A tutela de evidência}

10.1

A tutela de evidência no código de processo civil de 1973

No Código de Processo Civil de 1973 a técnica da tutela de evidência não era preconizada de forma coerente, uma vez que podíamos encontrar dispositivos esparsos prevendo tal tipo de tutela, como por exemplo, o artigo 273, II, a liminar na ação de depósito, a liminar nas ações possessórias, dentre outros explanados pela doutrina.

$\mathrm{O}$ artigo 273, II do CPC/73, conforme já mencionado anteriormente, trata da hipótese de antecipação de tutela quando ficar caracterizado o abuso de direito de defesa ou o manifesto propósito protelatório do réu.

Conforme assevera José Roberto dos Santos Bedaque,

temos uma hipótese de antecipação de tutela jurisdicional baseada na ideia de evidência e não de urgência, uma vez que o réu apresenta uma defesa inconsistente e/ ou procrastinatória, evidenciando o direito do autor, emergindo maior probabilidade de vitória de sua pretensão. Assim, concedia-se antecipadamente, aquilo que muito provavelmente viria ao final. ${ }^{89}$

Para Cassio Scarpinella Bueno, nesse caso a antecipação de tutela assume um caráter punitivo, verdadeiramente sancionatório, diante da conduta do réu. ${ }^{90}$

Apesar das divergências doutrinárias, entendemos que para a concessão da antecipação de tutela com fulcro no artigo 273, II do CPC/73, além do caráter sancionatório, a isso deve ser somada a verossimilhança da pretensão do autor, uma vez que trata-se de instrumento que tem por escopo redistribuir o ônus do tempo no processo, para o fim de minimizar o dano marginal deste, em face do alto grau de probabilidade de vitória da pretensão do autor.

Nesse sentido assevera José Roberto dos Santos Bedaque :

\footnotetext{
${ }^{89}$ BEDAQUE, J.R. dos S., op. cit., p. 326.
}

${ }^{90}$ BUENO, C. S., 2009, op. cit., p. 18. 
No caso do artigo 273, II, entendeu-se injustificável tivesse o autor de aguardar o final do processo, diante da postura inadequada do réu. Para preservar o mais possível a utilidade do provimento definitivo, autoriza-se antecipação provisória de seus efeitos. Embora não exista perigo causado por algum acontecimento extraordinário, há o risco sempre presente do dano marginal, que o legislador houve por bem eliminar, em consequência do abuso do direito de defesa ou do intuito protelatório do réu. Se o réu age dessa forma, por que sujeitar o autor às agurras do procedimento comum, para somente depois conceder-lhe a tutela? Entendeu-se conveniente a antecipação dos efeitos, não apenas como punição ao réu, mas também e principalmente como meio de assegurar integralmente o direito do autor. ${ }^{91}$

Outrossim, entendendo que a antecipação de tutela com base no artigo 273, II do CPC/73 não é simplesmente medida punitiva, uma vez que visa prestigiar a efetividade da tutela jurisdicional, podemos mencionar Teori Albino Zavasck.

Adverte o jurista:

A outra hipótese, decorrente do abuso de direito de defesa ou de manifesto propósito protelatório do réu (art 273, II), poder-se-á denominar, pelo menos para efeitos classificatórios, de antecipação punitiva. Embora não se trate propriamente de punição, dado que sua finalidade tem o sentido de prestar jurisdição sem protelações indevidas, a medida guarda semelhança, no que diz com as respectivas causas determinantes, com as penalidades impostas a quem põe obstáculos à seriedade e à celeridade da função jurisdicional, previstas no Código de Processo Civil. Daí a razão da denominação aqui adotada. ${ }^{92}$

Por fim, é importante ressaltar que esse tipo de provimento antecipatório se dá com base em cognição sumária, tendo como características a provisoriedade e revogabilidade, se diferenciando, portanto, do julgamento antecipado da lide.

\section{2}

\section{A tutela de evidência no Código de Processo Civil de 2015}

O CPC/15 passa a prever de forma expressa o instituto da tutela de evidência. Tal instituto, muito embora já viesse sendo sustentando pela doutrina antes mesmo da reforma processual que introduziu para a generalidade dos casos a tutela antecipada em 1994, somente veio a ser introduzido no nosso ordenamento jurídico com o advento da Lei 13.105/15.

\footnotetext{
${ }^{91}$ BEDAQUE, J.R. dos S., op. cit., p. 329-330.

${ }^{92}$ ZAVASCKI, Teori Albino. Antecipação de tutela. 5. ed. São Paulo: Saraiva, 2007. p 77-78.
} 
Ao propor a sua adoção, Luiz Fux a justificou:

A expressão direito evidente vincula-se a pretensões deduzidas em juízo nas quais o direito da parte revela-se evidente, tal como o direito líquido e certo que autoriza a concessão do mandamus ou o direito documentado do exequente.

São situações em que se opera mais do que o fumus boni iuris, mas a probabilidade da certeza do direito alegado, aliada à injustificada demora que o processo ordinário carreará até a satisfação do interesse do demandante, com grave desprestígio para o Poder Judiciário, posto que injusta a espera determinada. ${ }^{93}$

No seu Curso, o referido autor critica a utilização promíscua do processo cautelar, em busca de uma tutela sumária de direitos evidentes, asseverando;

A prática judiciária indica casos em que não se revela justa a demora da prestação jurisdicional, mercê de inexistir qualquer situação de perigo. Trata-se de casos de evidência, diametralmente distintos dos de "mera aparência" que se encenam no processo cautelar. Para esses, a inadequação do procedimento ordinário revela-se de pronto, reclamando uma atuação tão imediata quanto evidente o direito da parte, tal como ocorre com o mandado de segurança. ${ }^{94}$

Justificando a sua adoção no anteprojeto de 2010, asseverou que "a novidade também se operou quanto aos direitos líquidos e certos de uma parte em face da outra." 95

Entendeu a comissão que nessas hipóteses em que uma parte ostenta direito evidente, não se revelaria justo, ao ângulo do princípio da isonomia, postergar a satisfação daquele que se apresenta no processo com melhor direito, calcado em prova inequívoca, favorecendo a parte que, ao menos prima facie, não tem razão.

A versão final do Código de 2015 delineia a tutela de evidência em termos menos radicais, uma vez que admite a tutela liminar em duas hipóteses, vedando-a em duas outras. Em qualquer caso, tratou-a como espécie de tutela provisória, à qual se aplicam as regras gerais dos artigos 294 a 299, estendendo a elas, portanto, as mesmas características apontadas à tutela provisória, quais sejam, inércia, provisoriedade, instrumentalidade, revogabilidade, e sumariedade da cognição. Em todas as hipóteses, a tutela da evidência exige um juízo de probabilidade firme quanto à existência dos fatos alegados pelo autor, da existência do seu direito e da juridicidade e adequação do pedido pleiteado.

\footnotetext{
${ }^{93}$ FUX, Luiz. Tutela de segurança e Tutela de evidência. São Paulo: Saraiva, 1996. (fundamentos da tutela antecipada)

${ }^{94}$ Idem. Curso de direito processual civil. 3. ed. Rio de Janeiro: Forense, 2001. p. 1228. p. 305306.

${ }^{95}$ Idem.
} 
No Código de Processo Civil de 2015 a tutela de evidência está preconizada em seu Título III, no artigo 311, in verbis:

\section{TÍTULO III}

\section{DA TUTELA DA EVIDÊNCIA}

Art. 311. A tutela da evidência será concedida, independentemente da demonstração de perigo de dano ou de risco ao resultado útil do processo, quando:

I - ficar caracterizado o abuso do direito de defesa ou o manifesto propósito protelatório da parte;

II - as alegações de fato puderem ser comprovadas apenas documentalmente e houver tese firmada em julgamento de casos repetitivos ou em súmula vinculante;

III - se tratar de pedido reipersecutório fundado em prova documental adequada do contrato de depósito, caso em que será decretada a ordem de entrega do objeto custodiado, sob cominação de multa;

IV - a petição inicial for instruída com prova documental suficiente dos fatos constitutivos do direito do autor, a que o réu não oponha prova capaz de gerar dúvida razoável.

Parágrafo único. Nas hipóteses dos incisos II e III, o juiz poderá decidir liminarmente. ${ }^{96}$

O CPC/15 preconiza a tutela de evidência num único dispositivo legal, elencando quatro hipóteses, das quais duas delas (311, II e IV) não estavam preconizadas no $\mathrm{CPC} / 73$.

Devemos salientar que continuam existindo outras hipóteses de tutela de evidência, além daquelas previstas no artigo 311, como por exemplo, a liminar possessória, mas o fato é que o artigo 311 do CPC/15 traz uma regra geral de tutela provisória de evidência, de forma mais ampla do que o CPC/73.

Através da tutela de evidência, permite-se ao autor, mediante a demonstração da evidência de seu direito, a antecipação dos efeitos da tutela final. Trata-se de uma tutela provisória, que não tem como fundamento a urgência, porquanto fundada exclusivamente na evidência do direito, não se exigindo a demonstração do periculum in mora para a sua concessão, conforme se pode extrair de uma simples leitura do caput do artigo 311 do CPC.

Segundo Leonardo Greco podemos definir tutela da evidência como; "A tutela antecipada que acolhe no todo ou em parte o pedido principal do autor para tutelar provisoriamente, independentemente da urgência, provável direito, cuja

\footnotetext{
${ }^{96}$ Idem. nota n. 1. Art.311.
} 
existência se apresente prima facie indiscutível, nos casos preconizados no artigo 311 do CPC." 97

Tal dispositivo legal prevê que "a tutela de evidência será concedida, independentemente da demonstração de perigo de dano ou risco ao resultado útil do processo". 98

Os incisos do artigo 311 tratam de situações em está presente a evidência do direito, apta à concessão dessa modalidade de tutela provisória.

São elas:

> Inciso I: abuso do direito de defesa ou manifesto propósito protelatório

Essa hipótese é justamente aquela preconizada pelo revogado 273, II do $\mathrm{CPC} / 73$.

Assim, conforme já esclarecido anteriormente, a defesa do réu deve ser abusiva, inadequada, com vista a frustrar ou protelar a prestação jurisdicional. Devemos ressaltar que não há consenso doutrinário acerca do real sentido das expressões "abuso do direito de defesa" ou "manifesto propósito protelatório", pois são conceitos jurídicos indeterminados.

Flávio Luiz Yarshell e Helena Abodo advertem que “o manifesto propósito protelatório integra o abuso do direito de defesa." 99

$\mathrm{Na}$ linguagem da legislação francesa, a defesa, nesses casos, não é séria, devendo prestigiar a posição do autor que aparenta ter razão.

A doutrina continua a debater à luz do $\mathrm{CPC} / 15$, acerca da necessidade ou não da verossimilhança das alegações, quando constatada a presença do abuso do direito ou do manifesto propósito protelatório.

Há quem entenda que essa hipótese de tutela de evidência representa uma sanção, tendo por finalidade punir o comportamento do litigante de má-fé que abusou do direito de defesa ou apresentou manifestação protelatória, conforme mencionamos anteriormente ao comentarmos o artigo 273, II do CPC/73.

Já para outra parte da doutrina, não haveria natureza sancionatória, pois sua finalidade seria promover a igualdade substancial entre as partes, distribuindo a

\footnotetext{
${ }^{97}$ GRECO, L. op. cit., p. 204.

${ }^{98}$ Idem.

99 YARSHELL, Flávio Luiz e Abodo, Helena. As questões não tão evidentes sobre a tutela de evidência. Tutela provisória no novo CPC: dos 20 anos de vigência do artigo 273 do CPC/73 ao CPC/15. Coord. Cassio Scarpinella Bueno et. al. São Paulo: Saraiva, 2015. p. 457.
} 
carga do tempo do processo, a depender da maior ou menor probabilidade de ser fundada ou não a postulação do autor.

$>$ Inciso II: Quando as alegações de fato puderem ser comprovadas apenas documentalmente e houver tese firmada em julgamento de casos repetitivos ou em súmula vinculante.

Este inciso tem como fundamento o respeito aos precedentes obrigatórios, ou seja, estando documentalmente provados os fatos alegados pelo autor, poderá ser concedida a tutela de evidência, se houver probabilidade do pedido do autor, em razão de fundamento respaldado em tese jurídica já firmada em precedente obrigatório, mais propriamente em enunciado de súmula vinculante ou em julgamento de casos repetitivos. Isto porque, nos termos do artigo 926 do CPC/15, os tribunais têm o dever de uniformizar sua jurisprudência e mantê-la estável, íntegra e coerente. Em razão disso, juízes e tribunais devem observar tais precedentes judiciais.

Portanto, nessa situação há necessidade da presença de dois requisitos, quais sejam, a situação de fato apresentada pelo autor deve ser comprovada apenas por documentos e que a tese jurídica envolvendo a questão já se encontre pacificada, seja em sede de julgamento de casos repetitivos, seja por força de súmula vinculante. São requisitos cumulativos, não bastando a existência de apenas um deles.

Nesses casos, a tutela antecipada somente não será concedida se a situação do autor não se ajustar à ratio decidendi do precedente obrigatório, ou seja, não conceder-se-á a tutela antecipada se houver a necessidade de ser feita uma distinção no caso, em razão de alguma peculiaridade que afaste a aplicação do precedente obrigatório ou se vislumbrar a necessidade de revisão da tese jurídica. Nessas hipóteses, o réu deverá demonstrar a existência de uma distinção ou a necessidade de ser superado o entendimento firmado.

O parágrafo único do artigo 311 preconiza que em casos repetitivos, pode o juiz conceder a tutela provisória inaudita altera parte, para fazer aplicar o precedente do tribunal.

Lucas Burril de Macêdo entende que tal previsão é inconstitucional. ${ }^{100}$

\footnotetext{
${ }^{100}$ MACÊDO, Lucas Burril de. Antecipação de tutela por evidência e os precedentes obrigatórios. Revista de Processo. São Paulo: Revista dos Tribunais. v. 242, abr. 2015. p. 521-529.
} 
Todavia, entendemos que tal dispositivo legal é constitucional, uma vez que prestigia o sistema de precedentes, concretizando a razoável duração do processo no âmbito da litigiosidade repetitiva.

Inciso III: contrato de depósito

O inciso III trata de pedido reipersecutório fundado em prova documental adequada do contrato de depósito, caso em que será decretada a ordem de entrega do objeto custodiado, sob cominação de multa.

Essa hipótese não é rigorosamente uma novidade. O procedimento especial para a ação de depósito que estava preconizado nos artigos 901 a 906 do CPC/73 deixou de ser previsto no CPC/15. A ação de depósito passou a submeter-se ao procedimento comum, com a possibilidade de concessão de tutela provisória de evidência. Sendo assim, o pedido de cumprimento de obrigação reipersecutória decorrente de contrato de depósito autoriza a concessão de tutela provisória de evidência.

> Inciso IV: prova documental suficiente e ausência de prova capaz de gerar dúvida razoável pelo réu

O inciso IV, por sua vez, preconiza a concessão de tutela de evidência quando a petição inicial for instruída com prova documental suficiente dos fatos constitutivos do direito do autor e o réu não oponha prova capaz de gerar dúvida razoável.

Essa é uma hipótese que não permite a concessão liminar da tutela de evidência, pois dependerá da conduta do réu, ou seja, ao contestar, o réu não apresenta dúvida razoável às alegações comprovadas documentalmente pelo autor.

$\mathrm{Na}$ verdade, Leonardo Carneiro da Cunha adverte que essa hipótese é na verdade, de julgamento antecipado do mérito (355, I do CPC).

Assevera o jurista: "Estando os fatos constitutivos do direito comprovados por documentos, e não sendo necessária mais a produção de qualquer prova, é possível o julgamento antecipado do mérito, mas também é possível a tutela provisória de evidência."

${ }^{101}$ CUNHA, L. J. C. da, op. cit. p. 120. 
A finalidade e a utilidade dessa hipótese prevista no 311, IV do CPC relaciona-se com o afastamento do efeito suspensivo da apelação (CPC, 1012, p 1, V). "O juiz pode, na sentença, quando for a hipótese de julgamento antecipado do mérito, por serem suficientes os documentos apresentados, antecipar a tutela (desde que haja requerimento da parte), a fim de retirar da apelação o seu efeito suspensivo."102

Assim, podemos concluir que se bem aplicada, essa hipótese poderá contribuir sensivelmente para a efetividade do processo, porquanto o recurso de apelação, que tem como regra o efeito suspensivo, terá tal efeito afastado nessa situação, prestigiando, outrossim, a razoável duração do processo.

\section{Parágrafo único: liminar}

O parágrafo único do artigo 311 do CPC preconiza que só é permitido ao juiz decidir liminarmente a tutela de evidência, nas hipóteses previstas nos incisos II e III, ou seja, quando houver prova exclusivamente documental apresentada pelo autor, acompanhada de tese firmada em casos repetitivos ou súmula vinculante, ou quando se tratar de pedido reipersecutório fundado em prova documental do contrato de depósito.

Há, porém, argumentos contrários à opção adotada pelo legislador em possibilitar a liminar inaudita altera parte nessas situações de tutela de evidência. Parte da doutrina entende que por não haver risco de dano ou de inutilidade do processo, não existiria razão para que o juiz concedesse liminar sem a oitiva do réu, argumentando alguns ainda, não haver motivo para postergar o contraditório para um momento posterior.

102 CUNHA, Leonardo José Carneiro da. A Fazenda pública em juízo.13. São Paulo: Forense, 2016. p. 319-320. 


\section{PARTE II - Tutela provisória e a Fazenda Pública}

1

\section{Conceito de Fazenda Pública}

O Estado, em todas as suas esferas federativas, não possui condições materiais de exercer suas atividades típicas. Por essa razão, a Administração Pública se estrutura em direta e indireta. Segundo Diogo de Figueiredo Moreira Neto, a Administração Pública direta compreende os entes estatais políticos: União, Estados, Distrito Federal e os Municípios $^{103}$. Tais entes federativos se subdividem em órgãos, desprovidos de personalidade jurídica, que atuam como a própria pessoa jurídica de direito público em juízo.

Em razão da impossibilidade de exercer todas as suas atividades, a organização administrativa, tradicionalmente, se efetiva por meio de duas técnicas, quais sejam, a desconcentração e a descentralização.

$\mathrm{Na}$ desconcentração, existe uma especialização de funções dentro da sua própria estrutura estatal, sem que acarrete a criação de uma nova pessoa jurídica, mas tão somente uma distribuição interna de atividades dentro de uma mesma pessoa jurídica, com a criação de centros de competências, denominados órgãos públicos.

Já a técnica denominada descentralização representa a transferência de atividade administrativa para outra pessoa, física ou jurídica, integrante ou não do aparelho estatal. ${ }^{104}$

Segundo ensinamento de Hely Lopes Meirelles,

a Administração Pública quando ingressa em juízo por quaisquer de suas entidades estatais, por suas autarquias, por suas fundações públicas ou por seus órgãos que

\footnotetext{
${ }^{103}$ MOREIRA NETO, Diogo de Figueiredo. Curso de direito administrativo. 16. ed. Rio de Janeiro : Forense, 2014. p. 351.

104 OLIVEIRA, Rafael Carvalho Rezende. Curso de direito Administrativo. 5. ed. São Paulo: Método, 2017, p. 68.
} 
tenham capacidade processual, recebe a designação tradicional de Fazenda Pública, porque seu erário é que suporta os encargos patrimoniais da demanda. ${ }^{105}$

Assim, pela clássica lição de Hely Lopes Meirelles, a expressão Fazenda Pública está relacionada ao termo "Erário", representando assim, uma faceta financeira do ente público. Porém, sob uma ótica processual, podemos entender o termo para conceitua-lo como sendo a atuação do Estado em juízo.

Assim, Fazenda Pública representa a personificação do Estado, conforme anota Cândido Rangel Dinamarco, abrangendo as pessoas jurídicas de direito público. Dessa forma, estarão abrangidos pela expressão Fazenda Pública a União, Estados, Municípios, o Distrito Federal e suas respectivas autarquias e fundações públicas.

Segundo Marçal Justen Filho, a esse rol de pessoas jurídicas de direito público acrescem as agências, às quais se tem atribuído a natureza jurídica de autarquias especiais, significando dizer que estas se constituem de pessoas jurídicas de direito público destinadas a desempenhar atividade pública. ${ }^{106}$

Ainda, conforme anota Marçal, as agências podem ser executivas e reguladoras.

\begin{abstract}
As primeiras são entidades dotadas de competência para o desempenho direto de atividades administrativas, inclusive com atribuição de tarefas materiais, mormente no âmbito de desempenho daquilo que, no âmbito das concepções continentais, se considera como função pública e serviços públicos, mas eventualmente também no tocante a atividade econômica propriamente dita. Já as agências reguladoras disporiam de competência normativa, com poderes para disciplinar a prestação de serviços públicos por particulares ou o desempenho de atividades econômicas privadas, mas de interesse coletivo. ${ }^{107}$
\end{abstract}

No tocante à fundação pública, segundo anota José dos Santos Carvalho Filho, a corrente dominante defende a existência de duas espécies de fundações públicas: as fundações públicas de direito público e as de direito privado, sendo que as primeiras ostentam natureza jurídica de direito público e estas sendo dotadas de personalidade jurídica de direito privado. $\mathrm{Na}$ linha desse entendimento doutrinário, as fundações de direito público são caracterizadas como autarquias e,

\footnotetext{
${ }^{105}$ MEIRELLES, Hely Lopes. Direito administrativo brasileiro. 23. ed. atual. por Eurico de Andrade Azevedo, Délcio Balestero Aleixo e José Emmanuel Burle Filho. São Paulo: Malheiros, 1998. p.590.

${ }^{106}$ JUSTEN FILHO, Marçal. O direito das agências reguladoras independentes. São Paulo: Dialética, 2002. p. 391.

${ }^{107}$ Ibidem, p. 66.
} 
por isso, denominadas de fundações autárquicas ou autarquias fundacionais. Seriam na verdade uma espécie do gênero autarquias. ${ }^{108}$

Assim, podemos concluir que apenas as fundações públicas de direito público estão abrangidas pelo conceito de Fazenda Pública.

Em relação aos Conselhos de Fiscalização Profissional, muito embora não se enquadrem no conceito de Fazenda Pública, também se beneficiarão de garantias típicas das pessoas jurídicas de direito público, segundo entendimento jurisprudencial. O STJ, em sede de recurso representativo de controvérsia, admitiu que o benefício da intimação pessoal, previsto na Lei 6830/80 aos representantes judiciais da Fazenda Pública, também deveria ser estendido aos Conselhos de Fiscalização Profissional. (STJ REsp 1330473/SP)

Apesar de a Lei 9649/98 ter preconizado em seu artigo 58, caput e $\S 2^{\circ}$ que tais conselhos exercem atividades em caráter privado, estabelecendo, outrossim, que são dotados de personalidade jurídica de direito privado, o STF reconheceu implicitamente na ADI 1717-6, que esses conselhos possuem natureza jurídica de direito público.

Da mesma forma, cumpre salientar que as empresas públicas e sociedades de economia mista, apesar de não se enquadrarem no conceito de Fazenda Pública, excepcionalmente se beneficiam das regras processuais preconizadas apenas para as pessoas jurídicas de direito público, nos termos da jurisprudência do STF. Na linha do que foi decidido pelo STF, quando as estatais forem prestadoras de serviço público, com o escopo de proteção à continuidade do serviço público, estender-se-á a estas, as regras processuais aplicáveis à Fazenda Pública.

Portanto, podemos concluir que quando estiver em juízo alguma dessas pessoas jurídicas de direito público, esta poderá ser designada de Fazenda Pública, lembrando sempre da peculiaridade acima mencionada acerca dos Conselhos Profissionais. Ademais, as estatais prestadoras de serviços públicos muito embora sejam dotadas de personalidade jurídica de direito privado, também se beneficiarão das regras processuais aplicáveis à Fazenda Pública, como forma de proteção à continuidade do serviço que desenvolvem.

\footnotetext{
${ }^{108}$ CARVALHO FILHO, José dos Santos. Manual de direito administrativo. 25. ed. São Paulo:
} Atlas, 2012. p. 514. 


\section{2 \\ Prerrogativas Processuais da Fazenda Pública}

\section{1 Interesse público}

As regras processuais especiais que beneficiam a Fazenda Pública têm como principal fundamento o princípio da supremacia do interesse público.

Para a doutrina administrativista tradicional, esse princípio é visto como basilar à atuação do Estado. Celso Antônio Bandeira de Mello afirma que o princípio da supremacia do interesse público é verdadeiro axioma reconhecível no moderno Direito Público. Segundo o referido jurista, "tal princípio proclama a superioridade do interesse da coletividade, afirmando a prevalência do interesse público sobre o do particular, como condição até mesmo, de sobrevivência e asseguramento deste último."109

José Roberto de Moraes salienta que quando a Fazenda Pública está em juízo, está na defesa do erário e, em razão da desigualdade entre as partes, a Fazenda Pública, presentada pelo seu representante judicial, na defesa em juízo do interesse público, não pode ser equiparada ao particular. Afirma que:

No momento em que é condenada, sofre um revés, contesta uma ação ou recorre de uma decisão, o que se está protegendo em última análise é o erário. É exatamente essa massa de recurso que foi arrecadada e que supera aí sim, o interesse particular. Na realidade, a autoridade pública é mera administradora. ${ }^{110}$

Apesar da importância desse princípio, parte da doutrina vem questionando sua aplicação no direito público pátrio, trazendo como principal fundamento para esse questionamento a ascensão dos direitos fundamentais.

\footnotetext{
${ }^{109}$ MELLO, Celso Antônio Bandeira de. Curso de Direito Administrativo. 22. Ed. São Paulo: Malheiros, 2007. p. 66.

110 MORAES, Jose Roberto de. Prerrogativas processuais da Fazenda Pública. In. SUNDFELD, Carolos Ari; BUENO, Cassio Scarpinella. Direito Processual Público: A Fazenda Pública em juízo. São Paulo; Malheiros 2000. p. 69.
} 
Conforme entendimento de Humberto Ávila, a supremacia do interesse público sequer pode ser considerada um princípio, uma vez que sua concretização se dá por meio de uma regra abstrata de prevalência do interesse público, impedindo até mesmo a aplicação de métodos de ponderação a fim de definir o interesse que deverá prevalecer. Para ele, referido princípio não decorre de uma interpretação sistemática do Direito, muito pelo contrário, pois da análise das normas constitucionais, vê-se uma ascensão dos direitos fundamentais, que, se houvesse alguma regra de prevalência, essa seria em favor dos interesses privados. ${ }^{111}$

Odete Medauar também acentua a dificuldade na conceituação de interesse público. Salienta que a noção de interesse público começou a ser utilizada após a Revolução Francesa, como forma de os revolucionários justificarem a finalidades de seus atos. ${ }^{112}$

Seguindo esse mesmo entendimento, Marçal Justen Filho afirma não ser fácil definir interesse público, entendendo tratar-se de conceito jurídico indeterminado.

Por isso, para fins de definição do interesse público, é preciso que façamos uma interpretação sistemática do ordenamento jurídico pátrio. Primeiramente, cumpre salientar que a Constituição da República Federativa do Brasil de 1988 buscou trazer um extenso rol de direitos e garantias ao longo de todo o seu texto, mas especialmente indicando aqueles que o poder constituinte considerou como fundamentais no seu artigo $5^{\circ}$. Ademais, a CRFB/88 preconiza em seu artigo $1^{\circ}$, inciso III como fundamento da República a dignidade da pessoa humana.

De outro lado, apesar de não estar previsto expressamente a supremacia do interesse público, isto não quer significar que esse princípio não tenha sido tutelado pelo constituinte. Isto porque, trata-se de conceito jurídico indeterminado, que deverá ser concretizado pelos agentes públicos.

De acordo com os ensinamentos de Gustavo Binenbojm, apesar de o Estado ter que perseguir o interesse público, esse dificilmente pode ser definido estaticamente, pois deve ser buscado em primeiro lugar na Constituição, e eventualmente precisará de uma ponderação de direitos previstos, a fim de

111 ÁVILA, Humberto. Repensando a supremacia do interesse público sobre o particular. In: SARMENTO, Daniel (Org.) Interesses públicos versus interesses privados: desconstruindo o princípio da supremacia do interesse público. 3. tir. Rio de Janeiro: Lumen Juris. p. 185.

${ }_{112}$ MEDAUAR, Odete. Direito administrativo em evolução. São Paulo: Malheiros. 2003. p. 188. 
verificar qual ou quais interesses representam aquilo que deve ser perseguido pelo Poder Público.

Para o autor, "o melhor interesse público somente pode ser definido a partir de um procedimento racional, com juízos de ponderação entre direitos individuais e coletivos". 113

Luís Roberto Barroso afirma que "a dignidade da pessoa humana possui superioridade prima facie na ponderação a ser realizada, em razão da primazia dada a ela pela Constituição Federal". ${ }^{114}$

No entanto, trata-se de temática polêmica, uma vez que para outra parte da doutrina, o parâmetro utilizado é a superioridade dos direitos fundamentais, sem qualquer restrição.

Diogo de Figueiredo Moreira Neto salienta que:

é a própria ordem jurídica que estabelece uma hierarquia axiológica fundamental, ao reconhecer a precedência natural, que apenas expressada no texto constitucional, das liberdades, direitos e garantias fundamentais, excepcionalmente são temperadas pela definição legal de um específico interesse público que justifique limitá-las ou condicioná-las. Portanto, os direitos e garantias fundamentais só cedem ante uma expressa preceituação constitucional e, assim mesmo, restritamente, quando como e onde essa supremacia se impuser. ${ }^{115}$

Também nessa linha, Marçal Justen Filho afirma que a atividade administrativa do Estado Democrático de Direito subordina-se, então, a um critério fundamental que é anterior à supremacia do interesse público. Trata-se da supremacia e indisponibilidade dos direitos fundamentais. ${ }^{116}$

Assim, não podemos afirmar que o princípio da supremacia do interesse público significa que os interesse estatais sempre prevalecerão sobre os dos administrados, mas que o interesse público, definido a partir da técnica da ponderação, deve prevalecer em determinada atividade concreta sobre interesses isolados, sejam particulares, sejam estatais.

\footnotetext{
113 BINENBOJM, Gustavo. Da supremacia do interesse público ao dever de proporcionalidade: um novo paradigma para o direito administrativo. In: SARMENTO. Daniel (Org.) Interesses públicos versus interesses privados: desconstruindo a supremacia do interesse público. Rio de Janeiro: Lumen Juris. p. 167.

114 BARROSO, Luís Roberto. Curso de Direito Constitucional contemporâneo: os conceitos fundamentais e a construção de um novo modelo. 2. ed. São Paulo: Saraiva,2010. p. 73.

${ }^{115}$ MOREIRA NETO, Diogo de Figueiredo. Curso de direito administrativo. 16. ed. Rio de Janeiro: Forense, 2014. p. 87.

116 JUSTEN FILHO, M., op. cit., p . 45.
} 


\section{2}

\section{A igualdade no processo}

A CRFB $/ 88^{117}$ preconiza em seu artigo $5^{\circ}$ que todos são iguais perante a lei.

Devemos analisar esse dispositivo constitucional não apenas sob uma visão puramente formal da isonomia. Isto porque, trata-se de uma garantia de igualdade também sob seu aspecto material, no sentido de que seja dado tratamento igual a todos os iguais e desigual aos desiguais.

Segundo Celso Antônio Bandeira de Mello, a lei não deve ser fonte de privilégios ou perseguições, mas instrumento regulador da vida social que necessita tratar equitativamente todos os cidadãos.

Afirma ainda o autor que:

O princípio da igualdade interdita tratamento desuniforme às pessoas. Sem embargo, consoante se observou, o próprio da lei, sua função precípua, reside exata e precisamente em dispensar tratamentos desiguais. Isto é, as normas legais nada mais fazem que discriminar situações, à moda que as pessoas compreendidas em umas ou em outras vêm a ser colhidas por regimes diferentes. Donde, a algumas são deferidos determinados direitos e obrigações que não assistem a outras, por abrigadas em diversa categoria, regulada por diferente plexo de obrigações e direitos. ${ }^{118}$

Dessa forma, o princípio da igualdade deve levar em conta as diversidades de cada um, pois é antiga a lição de Aristóteles, segundo a qual, a igualdade consiste em tratar igualmente os iguais e desigualmente os desiguais na medida em que se desigualam. É por essa razão que no momento da elaboração do texto normativo, o legislador já leva em consideração o fator de discriminação, sempre em consonância com o princípio da igualdade, uma vez que o ordenamento jurídico não tolera discriminações que não pautadas pelo princípio da razoabilidade.

No processo civil, o princípio da igualdade está preconizado no artigo $7^{\circ}$ do CPC. A igualdade processual é assegurada na paridade de armas (igualdade formal) e no equilíbrio processual (igualdade material). O contraditório deve ser exercido pelas partes em igualdade de condições.

\footnotetext{
${ }^{117}$ Idem, nota n. 9.

118 MELLO, Celso Antônio Bandeira de. Conteúdo Jurídico do princípio da igualdade. 3. ed. São Paulo: Malheiros, 2002. p. 10-13.
} 
No entanto, há regras processuais diferenciadas com o escopo de alcançar o equilíbrio processual, justamente porque uma das partes apresenta peculiaridades em relação às demais. Nesse sentido, podemos citar a Fazenda Pública.

Há regras especiais conferidas à Fazenda Pública, entre as quais, sobressaem a prerrogativa de prazos diferenciados, com intimação pessoal de seu representante legal, a remessa necessária, ônus da prova, dentre outras.

Há na doutrina quem entenda pela inconstitucionalidade dessas regras processuais diferenciadas conferidas à Fazenda Pública. Segundo Rafael Sirangelo de Abreu, "as prerrogativas conferidas à Fazenda Pública são em princípio ilegítimas, pois desequilibram posições processuais, podendo pontualmente ser justificadas se, concretamente, forem necessárias para a concretização do contraditório-influência no processo". 119

No entanto, entendemos que não há qualquer inconstitucionalidade no tocante às regras processuais diferenciadas conferidas à Fazenda Pública, pelas razões que se passa a analisar.

O juiz na condução do processo, deve sempre conferir às partes uma igualdade de oportunidades, para que seja exercido o contraditório, com chances reais de influenciar no seu convencimento, isto é, as partes devem ter elementos suficientes a fim de demonstrar o acerto de sua tese ou de sua defesa. Dessa forma, os benefícios processuais conferidos à Fazenda Pública devem ser analisados sob à ótica dos direitos fundamentais do contraditório e da ampla defesa, preconizados no artigo $5^{\circ}$, inciso LV, da CRFB/88. ${ }^{120}$

Ampla defesa, segundo Leonardo Greco, configura um elemento do contraditório. $^{121}$

Podemos conceituar ampla defesa, conforme lição de Delosmar Mendonça $\mathrm{Jr}$, como sendo o direito fundamental de ambas as partes, consistindo no conjunto de meios adequados para o exercício do adequado contraditório. ${ }^{122}$

Já o contraditório, conforme leciona Antônio do Passo Cabral é tradicionalmente definido por meio do binômio informação- reação. Assim,

\footnotetext{
119 ABREU, Rafael Sirangelo de. Igualdade e processo: posições processuais equilibradas e unidade do direito. São Paulo: Revista dos Tribunais, 2015. p. 197.

${ }^{120}$ Idem, nota n. 9.

${ }^{121}$ GRECO, Leonardo. O princípio do contraditório. In: __. Estudos de direito processual. Campos dos Goytacazes: Ed. Faculdade de Direito de Campos, 2005. p. 548.

${ }^{122}$ MENDONÇA JR Delosmar. Princípios da ampla defesa e da efetividade no processo civil brasileiro. São Paulo: Malheiros, 2001. p. 55.
} 
através do direito à informação, os interessados são cientificados de uma demanda ou de atos processuais relacionados a ela que possam ter aptidão de lhe causar prejuízos. No tocante ao direito de reação, ou seja, direito à manifestação, os interessados vêm a ser informados da demanda ou de um ato da relação processual a fim de defenderem seus interesses.

No entanto, o direito fundamental em questão passou por uma remodelagem, visando se adequar à efetividade da tutela jurisdicional. Com efeito, num Estado Democrático de Direito, marcado pela dialogicidade dos indivíduos na construção dos destinos estatais, o contraditório exige não apenas a informação-reação, mas um efetivo direito de influência das partes na formação da decisão final.

Dessa forma, é imprescindível que a regra que institui a prerrogativa processual à Fazenda Pública passe pelo crivo do contraditório, pois caso acarrete um desequilíbrio injustificado entre as partes, não será admissível.

Portanto, podemos concluir que tais benefícios são prerrogativas processuais instituídas em favor de pessoas jurídicas de direito público em razão de suas características que as diferencia de outras pessoas e entes, como forma de prestigiar o princípio da igualdade.

Contudo, não é possível afirmar de forma genérica e abstrata que a instituição de benefícios processuais à Fazenda Pública seja constitucional ou não. Isto porque, é necessário a verificação de cada previsão, a fim de controlar sua constitucionalidade no que toca à observância da igualdade.

Como justificativa dos prazos diferenciados e da remessa necessária, podemos alegar o excessivo volume de trabalho, dificuldades estruturais, burocracia da atividade administrativa. Já em relação ao ônus da prova, podemos justifica-lo mencionando o princípio da presunção da legitimidade dos atos administrativos.

Portanto, em prestígio ao princípio da isonomia, aliado ao fato de a Fazenda Pública atuar em prol do interesse público, justifica-se a manutenção das prerrogativas processuais instituídas em favor das pessoas jurídicas de direito público.

Há que salientar que esses benefícios criados em favor do Poder Público em nada se assemelham à privilégios. Isto porque, esses, por seu turno são benefícios instituídos sem respaldo na igualdade material, indo de encontro com a 
razoabilidade exigida das leis, não se justificando à luz do ordenamento jurídico pátrio. 


\section{3 \\ Tutela antecipada em face da Fazenda Pública à luz do CPC/73}

No tocante à aplicação do instituto da Tutela Antecipada em face da Fazenda Pública, o CPC/73 era omisso. Por essa razão, a doutrina se dividia acerca da possibilidade de sua aplicação em face das pessoas jurídicas de direito público.

Autores, como por exemplo, Carlos Ari Sundfeld e Cassio Scarpinella Bueno, defendiam a não aplicação da tutela antecipada de forma genérica, com fulcro no artigo 273 do CPC/73 à Fazenda Pública, trazendo como argumentos para as suas teses, o fato de que o reexame necessário seria obstáculo à sua aplicação. Argumentavam que a sentença, que em regra possui cognição exauriente, está sujeita à confirmação pelo Tribunal para produzir eficácia plena. Ao revés, a tutela antecipada é proferida em cognição sumária, e por isso, não poderia ser cabível em face de pessoas jurídicas de direito público, caso contrário essa decisão teria mais força em face da Fazenda do que a própria sentença de mérito, uma vez que aquela não estaria sujeita ao reexame necessário por falta de previsão legal.

Outro argumento trazido pelos referidos juristas, seria o fato de que as condenações judiciais proferidas contra a Fazenda estão sujeitas ao regime do precatório, preconizado no artigo 100 da CRFB/88, ou seja, é necessário o trânsito em julgado da decisão exequenda para a inclusão de verba no orçamento da entidade de direito público para pagamento de suas condenações e a satisfação do precatório deverá respeitar a ordem cronológica de sua apresentação.

Dessa forma, para esses autores, caso fosse concedida uma antecipação dos efeitos da sentença em face da Fazenda Pública com consequências pecuniárias, haveria afronta direta à $\mathrm{CRFB} / 88$, pois restaria vulnerado o dispositivo constitucional que exige observância da ordem cronológica para pagamentos. ${ }^{123}$

\footnotetext{
${ }^{123}$ GIANESINI, Rita. Descabimento da Tutela antecipada e da execução provisória contra a Fazenda Pública In: SUNDFELD, Carlos Ari; BUENO, Cassio Scarpinella. Direito processual Público: A Fazenda em juízo. São Paulo: Malheiros, 2003. p. 170-180.
} 
Entretanto, a jurisprudência dos Tribunais Superiores reiteradamente já vinha admitindo a antecipação de tutela em face da Fazenda Pública sob à égide do $\mathrm{CPC} / 73$, como se pode verificar através dos julgados colacionados abaixo.

Ementa Processual Civil. Militar. Reintegração. Antecipação de tutela. Possibilidade. Situação não incluída no art. $1^{\circ}$ da Lei n. 9.494/1997.

1. O disposto nos arts. $1^{\circ}$ e $2^{\circ}$-B da Lei $9.494 / 1997$ deve ser interpretado de forma restritiva, motivo pelo qual é permitida a concessão de tutela antecipatória para reintegração de militar ao serviço ativo e realização de tratamento de saúde, na medida em que não se pretende reclassificação ou equiparação de servidor público, ou concessão de aumento ou extensão de vantagens. Precedentes.

2. Inviável a verificação de existência dos requisitos necessários para a concessão de antecipação de tutela, porquanto implica revisão do conjunto fático-probatório dos autos. Incidência da Súmula n. 7/STJ. 3. Agravo regimental improvido. ${ }^{124}$

Ementa Direito Administrativo. Processual Civil. Agravo regimental no agravo de instrumento. Concurso público. Liminar. Nomeação e posse em cargo público. Afronta aos arts. $1^{\circ}, \S 3^{\circ}$, da Lei $8.437 / 92$ e $1^{\circ}$ da Lei 9.494/97. não ocorrência. Precedente do STJ. Agravo Improvido.

1. A vedação contida nos arts. $1^{\circ}, \S 3^{\circ}$, da Lei $8.437 / 92$ e $1^{\circ}$ da Lei $9.494 / 97$, quanto à concessão de antecipação de tutela contra a Fazenda Pública nos casos de aumento ou extensão de vantagens a servidor público, não se aplica nas hipóteses em que o autor busca sua nomeação e posse em cargo público, em razão da sua aprovação no concurso público. Precedente do STJ.

2. Agravo regimental improvido. ${ }^{125}$

124 BRASIL. Jurisprudência. Acórdão unânime da quinta Turma do STJ, AgRg no REsp 1120170/RS, Rel. Min Jorge Mussi, j. 03/11/2009.

125 Idem. Acórdão unânime da Quinta Turma do STJ, AgRg no Ag 1161985/ES, Rel. Min Arnaldo Esteve. J. 22/06/2010 DJU 02/08/2010. 


\section{4}

\section{Tutela de urgência contra a Fazenda Pública}

\section{1 Cabimento}

A Tutela de Urgência cautelar e satisfativa são cabíveis contra a Fazenda Pública, desde que observadas as vedações legais preconizadas no ordenamento jurídico pátrio, tal como será analisado a seguir. Assim, podemos afirmar que nas hipóteses não abrangidas pelas vedações legais, é possível a concessão de tutela de urgência em face da Fazenda Pública.

\section{2 Vedações legais à tutela de urgência em face da Fazenda Pública}

O ordenamento jurídico brasileiro preconiza vedações à concessão de tutela de urgência contra a Fazenda Pública em diversas legislações.

Primeiramente, cumpre ressaltar que a Lei 12.016/2009, que regulamenta o procedimento do mandado de segurança, veda a concessão de liminar nas hipóteses previstas no $\S 2^{\circ}$ do artigo $7^{\circ}$, conforme se pode observar pela transcrição do dispositivo legal:

Art. $7^{\circ} \S 2^{\text {o }}$ Não será concedida medida liminar que tenha por objeto a compensação de créditos tributários, a entrega de mercadorias e bens provenientes do exterior, a reclassificação ou equiparação de servidores públicos e a concessão de aumento ou a extensão de vantagens ou pagamento de qualquer natureza. ${ }^{126}$

No mesmo sentido, o artigo 1059 do $\mathrm{CPC} / 15$ preconiza que à tutela requerida contra a Fazenda Pública aplica-se o disposto nos artigos $1^{\circ}$ a $4^{\circ}$ da Lei 8437, de 30 de junho de 1992, e no art $7^{\circ}$ : $\S 2^{\circ}$ da lei 12016/09: “Art. 1.059. À tutela provisória requerida contra a Fazenda Pública aplica-se o disposto nos arts.

126 BRASIL. Lei n. 12.016 de 07 de agosto de 2009. Planalto. Disponível em: < http://www.planalto.gov.br/ccivil_03/_ato2007-2010/2009/lei/112016.htm>. Acesso em: 10 dez. 2018. 
$1^{\circ}$ a $4^{\circ}$ da Lei $n^{\circ} 8.437$, de 30 de junho de 1992 , e no art. $7^{\circ}, \S 2^{\circ}$, da Lei $n^{\circ}$ 12.016, de 7 de agosto de 2009." 127

Podemos verificar que esses dispositivos legais cuidam sobretudo de hipóteses que causam impacto financeiro para a Fazenda, que ao fim e ao cabo, poderão acarretar irreversibilidade de seus efeitos, no caso de sua revogação.

São os casos de compensação tributária e de concessão de aumento de servidor, bem como vedação à concessão de liminar que vise à liberação de bens e mercadorias provenientes do exterior.

Todas essas vedações são antigas em nosso ordenamento jurídico. Veja-se que a vedação em relação à compensação tributária, já se encontrava pacificada pelo Superior Tribunal de Justiça, por meio da súmula 212: “A compensação de créditos tributários não pode ser deferida em ação cautelar ou por medida liminar ou antecipatória." 128

A vedação à concessão de liminar que vise a liberação de bens e de mercadorias estrangeiras já estava disciplinada por meio da Lei 2.770/56. ${ }^{129}$

No caso da entrega de mercadorias e de bens provenientes do exterior, a não liberação destes extrajudicialmente pela Administração pode se dar por motivos de saúde pública ou por motivos tributários, que justificam uma opção legislativa pela não concessão de medida de urgência.

Por oportuno, transcreve-se o julgado do STJ:

Processual Civil e Administrativo. Violação ao Art. 535 do CPC. Inocorrência. Multa do Art. 538, p. ún., do CPC. Afastamento. Aplicação da Súmula n. 98 desta corte superior. Poder de polícia. Mercadorias provenientes do estrangeiro. Tutela antecipada visando sua liberação. Impossibilidade. Art. $1^{\circ}$ da Lei n. 2.770/56.

(...)

3. Embora o Supremo Tribunal Federal (STF) venha sinalizando pela necessidade de conferir interpretação conforme às normas que vedem genericamente a concessão de tutela antecipada, não existe pronunciamento específico acerca do art. $1^{\circ}$ da Lei n. 2.770/56, que permanece vigente e, portanto, deve ser aplicada, sob pena de desrespeito à Súmula Vinculante n. 10.

4. $\mathrm{Na}$ espécie, trata-se de mercadorias provenientes do exterior apreendidas pelo Fisco em razão da suspeita de subfaturamento, com possível aplicação da pena de perdimento. Plenamente incidente, pois, o art. $1^{\circ}$ da Lei n. 2.770/56. Precedentes.

\footnotetext{
127 Idem.

${ }^{128}$ BRASIL. Súmula 212. Supremo Tribunal de Justiça. Disponível em: <https://ww2. stj. jus. br / docs.../ stj-revista-sumulas-2010_15_capSumula212alterada.pdf >. Acesso em: 10 dez. 2018.

129 BRASIL. Lei $\mathrm{n}^{\circ} \mathbf{2 . 7 7 0}$, de 4 de maio de 1956. Disponível em: < www.planalto.gov.br/ ccivil_ 03 /LEIS/1950-1969/L2770.htm >. Acesso em: 10 dez. 2018.
} 
5. O art. 273, § $2^{\circ}$, do CPC veda a concessão de tutela em situações nas quais haja perigo de irreversibilidade do provimento judicial. Frise-se que o desembaraço antecipado das mercadorias (kits de cartas de baralho), considerando ser possível a venda a varejo, pode impedir eventual cominação do perdimento.

6. Recurso especial parcialmente provido. ${ }^{130}$

Por sua vez, a restrição à concessão de liminares objetivando a reclassificação ou equiparação de servidores públicos ou à concessão de aumento ou extensão de vantagens já estava preconizada nas Leis 4.348/64 ${ }^{131}$ e 5.021/66 ${ }^{132}$.

Devemos esclarecer, todavia, que nessa última hipótese, o Supremo Tribunal Federal entende ser a regra aplicável apenas aos servidores ativos, mas não aos inativos, pois para estes estaria em jogo verba de caráter previdenciário, conforme se pode extrair da Súmula 729 da Corte Suprema: "a decisão na Ação Direta de Constitucionalidade 4 não se aplica à antecipação de tutela em causa de natureza previdenciária."133

Esses impedimentos que seriam próprios para o mandado de segurança, aplicam-se também às providências liminares concedidas em ações cautelares.

Com efeito, a Lei 8.437, de 30 de junho de 1992, veda a concessão de liminares em ações cautelares quando igualmente impedida na via do mandado de segurança. Transcreve-se o dispositivo legal para melhor compreensão:

Art. $1^{\circ}$ Não será cabível medida liminar contra atos do Poder Público, no procedimento cautelar ou em quaisquer outras ações de natureza cautelar ou preventiva, toda vez que providência semelhante não puder ser concedida em ações de mandado de segurança, em virtude de vedação legal. ${ }^{134}$

Repetindo a mesma regra referente ao mandado de segurança, o artigo $3^{\circ}$ da lei 8437/92, determina que no caso de a cautelar importar em outorga ou adição de vencimentos ou reclassificação funcional, o recurso de apelação e, até mesmo, o reexame necessário contenham efeito suspensivo, obstando o cumprimento imediato da medida.

\footnotetext{
${ }^{130}$ BRASIL. Jurisprudência. Acórdão unanime da $2^{\text {a }}$ Turma do STJ, Resp 1.184.720/DF, rel. Min. Mauro Campbell Marques, j. 05/08/2010, Dje de 1\%09/10.

${ }^{131}$ BRASIL. Lei n. 4.348 de 26 de junho de 1964. Planalto. Disponível em: < http:// www. planalto.gov.br/ccivil_03/Leis/L4348.htm>. Acesso em: 18 nov. 2018.

132 BRASIL. Lei n. 5.021 de 09 de junho de 1966. Planalto. Disponível em: < http:// www. planalto.gov.br/ccivil_03/leis/L5021.htm>. Acesso em: 19 nov. 2018.

${ }^{133}$ BRASIL. Súmula 729. Supremo Tribunal Federal. Disponível em: < www.stf.jus.br/portal /jurisprudencia/menuSumarioSumulas.asp?sumula=2705 >. Acesso em: 19 nov. 2018.

${ }^{134}$ BRASIL. Lei 8.437, de 30 de junho de 1992. Planalto. Disponível em: <https://www. planalto . gov.br/ccivil_03/leis/L8437.htm>. Acesso em: 23 nov. 2018.
} 
Art. $3^{\circ} \mathrm{O}$ recurso voluntário ou ex officio, interposto contra sentença em processo cautelar, proferida contra pessoa jurídica de direito público ou seus agentes, que importe em outorga ou adição de vencimentos ou de reclassificação funcional, terá efeito suspensivo. ${ }^{135}$

A Lei 8.437/92 veda também de forma expressa a concessão de liminares em ações cautelares quando impugnado ato de autoridade sujeita, na via do mandado de segurança, à competência originária de tribunal.

É o que se depreende do teor do $\S 1^{\circ}$ do artigo $1^{\circ}$ da mencionada lei 8.437/92, cuja transcrição se impõe: “\$ $1^{\circ}$ Não será cabível, no juízo de primeiro grau, medida cautelar inominada ou a sua liminar, quando impugnado ato de autoridade sujeita, na via de mandado de segurança, à competência originária de tribunal." $" 136$

Leonardo Carneiro da Cunha adverte que:

Essa restrição contida no $\S 1^{\circ}$ do artigo $1^{\circ}$ da Lei $n^{\circ} 8.437$, de 1992 , não se aplica aos processos de ação popular e de ação civil pública, tal se infere do teor do $\S 2^{\circ}$ daquele mesmo artigo $1^{\circ}$. Tais ações - que detêm igualmente dignidade constitucional - podem provocar a concessão de provimentos liminares ou de urgência, mesmo que o ato impugnado seja de autoridade sujeita, na via de mandado de segurança, à competência originária de tribunal. ${ }^{137}$

Nos termos do $\S 3^{\circ}$ do artigo $1^{\circ}$ da Lei $n^{\circ} 8.437$, de 1992, "não será cabível medida liminar que esgote, no todo ou em parte, o objeto da ação". ${ }^{138}$

Já o art. $1^{\circ} \S 5^{\circ}$ da Lei $8437 / 92$, no mesmo sentido do $\S 2^{\circ}$ do artigo $7^{\circ}$ da Lei 12016/09, preconiza que não é possível medida que defira a compensação de créditos tributários ou previdenciários.

As disposições restritivas de liminares em mandado de segurança aplicamse aos casos de antecipação de tutela, nos termos do $\S 5^{\circ}$ do artigo $7^{\circ}$ da Lei 12.016/09: "§ $5^{\circ}$ As vedações relacionadas com a concessão de liminares previstas neste artigo se estendem à tutela antecipada a que se referem os arts. 273 e 461 da Lei no 5.869, de 11 de janeiro de 1973 - Código de Processo Civil.”139

\footnotetext{
135 Idem.

136 Idem.

${ }^{137}$ CUNHA, Leonardo Carneiro da. Tutela Jurisdicional de Urgência-Relatório Nacional (Brasil). Texto preparado para o Congresso Argentina-Brasil de direito processual. São Paulo. Dez 2012.

${ }^{138}$ Idem, nota n. 133.

139 BRASIL. Lei n. 12.016 de 07 de agosto de 2009. Planalto. Disponível em: < http://www. planalto.gov.br/ccivil_03/_ato2007-2010/2009/lei/112016.htm>. Acesso em: 10 dez. 2018.
} 
A Lei 9.494 de 10 de setembro de 1997, no mesmo sentido estendeu essas regras impeditivas de medidas cautelares contra a Fazenda Pública às hipóteses de antecipação de tutela, consoante se observa pela transcrição de seu artigo $1^{\circ}$, que estabelece:

Art. $1^{\circ}$ Aplica-se à tutela antecipada prevista nos arts. 273 e 461 do Código de Processo Civil o disposto nos arts. $5^{\circ}$ e seu parágrafo único e $7^{\circ}$ da Lei $n^{\circ} 4.348$, de 26 de junho de 1964 , no art. $1^{\circ}$ e seu $\S 4^{\circ}$ da Lei $n^{\circ} 5.021$, de 9 de junho de 1966 , e nos arts. $1^{\circ}, 3^{\circ}$ e $4^{\circ}$ da Lei $n^{\circ} 8.437$, de 30 de junho de $1992 .{ }^{140}$

Portanto, podemos concluir que não será cabível a tutela antecipada contra a Fazenda Pública nos seguintes casos:

a) quando tiver por finalidade a reclassificação ou equiparação de servidores públicos, ou a concessão de aumento ou extensão de vantagens (Lei $\mathrm{n}^{\mathrm{o}}$ 12.016/2009, art. $7^{\circ}, \S 2^{\circ}$ ). Nesse caso, além de vedada a antecipação da tutela, a sentença final somente poderá ser executada após o trânsito em julgado (Lei ${ }^{\circ}$ $12.016 / 2009$, art. $14, \S 3^{\circ}$ ), exatamente porque o recurso de apelação e o reexame necessário têm efeito suspensivo (Lei no 8.437/1992, art. $3^{\circ}$ );

b) quando objetivar a reclassificação ou equiparação de servidores públicos, bem assim a concessão de aumento ou extensão de vantagens (Lei $\mathrm{n}^{\circ}$ 12.016/2009, art. $7^{\circ}, \S 2^{\circ}$ );

c) toda vez que providência semelhante não puder ser concedida em ações de mandado de segurança, em virtude de vedação legal (Lei n ${ }^{\circ} 8.437 / 1992$, art. $1^{\text {o }}$; Lei $n^{\circ} 12.016 / 2009$, art. $7^{\circ}, \S 5^{\circ}$ );

d) quando impugnado, na primeira instância, ato de autoridade sujeita, na via do mandado de segurança, à competência originária do tribunal (Lei $\mathrm{n}^{\circ}$ $8.437 / 1992$, art. $1^{\mathrm{o}}, \S 1^{\circ}$ );

e) quando a medida esgotar, no todo ou em parte, o objeto da ação (Lei ${ }^{\circ}$ $8.437 / 1992$, art. $\left.1^{\circ}, \S 3^{\circ}\right)$;

f) para compensação de créditos tributários ou previdenciários (Lei n ${ }^{\circ}$ $8.437 / 1992$, art. $1^{\mathrm{o}}, \S 5^{\mathrm{o}}$; Lei $\mathrm{n}^{\mathrm{o}} 12.016 / 2009$, art. $7^{\mathrm{o}}, \S 2^{\mathrm{o}}$ );

g) para entrega de mercadorias e bens provenientes do exterior (Lei $n^{\circ}$ $12.106 / 2009$, art. $7^{\circ}, \S 2^{\circ}$ ).

\footnotetext{
${ }^{140}$ BRASIL. Lei 9.494 de 10 de setembro de 1997. Planalto. Disponível em: < http://www. planalto.gov.br/ccivil_03/leis/L9494.htm>. Acesso em: 10 dez. 2018.
} 
Essas regras estão igualmente preconizadas no artigo $2^{\circ}$-B da Lei 9.494/1997;

Art. $2^{\circ}$-B. A sentença que tenha por objeto a liberação de recurso, inclusão em folha de pagamento, reclassificação, equiparação, concessão de aumento ou extensão de vantagens a servidores da União, dos Estados, do Distrito Federal e dos Municípios, inclusive de suas autarquias e fundações, somente poderá ser executada após seu trânsito em julgado. (Incluído pela Medida provisória $\mathrm{n}^{\circ}$ 2.18035 , de 2001)..$^{141}$

Nesse sentido, vale lembrar que o STF já teve que analisar a constitucionalidade das vedações à concessão de liminares em face da Fazenda Pública instituídas pela Medida Provisória. 173, de 1990, reconhecendo a sua constitucionalidade.

Ementa: ação direta de inconstitucionalidade contra a medida provisória 173, de 18.3.90, que veda a concessão de 'medida liminar em mandado de segurança e em ações ordinárias e cautelares decorrentes das medidas provisórias números 151, 154, 158,160,162, 165, 167 e 168': indeferimento do pedido de suspensão cautelar da vigência do diploma impugnado: Razões dos votos vencedores. Sentido da inovadora alusão constitucional a plenitude da garantia da jurisdição contra a ameaça a direito: Ênfase à função preventiva de jurisdição, na qual se insere a função cautelar e, quando necessário, o poder de cautela liminar. Implicações da plenitude da jurisdição cautelar, enquanto instrumento de proteção ao processo e de salvaguarda da plenitude das funções do poder judiciário. Admissibilidade, não obstante, de condições e limitações legais ao poder cautelar do juiz. A tutela cautelar e o risco do constrangimento precipitado a direitos da parte contrária, com violação da garantia do devido processo legal. Consequente necessidade de controle da razoabilidade das leis restritivas ao poder cautelar. Antecedentes legislativos de vedação de liminares de determinado conteúdo. Critério de razoabilidade das restrições, a partir do caráter essencialmente provisório de todo provimento cautelar, liminar ou não. Generalidade, diversidade e imprecisão de limites do âmbito de vedação de liminar da MP 173, que, se lhe podem vir, a final, a comprometer a validade, dificultam demarcar, em tese, no juízo de delibação sobre o pedido de sua suspensão cautelar, até onde são razoáveis as proibições nela impostas, enquanto contenção ao abuso do poder cautelar, e onde se inicia, inversamente, o abuso das limitações e a consequente afronta a plenitude da jurisdição e ao poder judiciário. Indeferimento da suspensão liminar da MP 173, que não prejudica, segundo o relator do acórdão, o exame judicial em cada caso concreto da constitucionalidade, incluída a razoabilidade, da aplicação da norma proibitiva da liminar. Considerações, em diversos votos, dos riscos da suspensão cautelar da medida impugnada. ${ }^{142}$

Através do referido julgado, podemos observar que o STF entendeu que não vulnera a garantia fundamental de acesso à justiça a previsão abstrata de

\footnotetext{
${ }^{141}$ Idem.

142 BRASIL. Jurisprudência. Supremo Tribunal Federal. ADI 223 MC Rel Min Paulo Brossard, Relator p/ acórdão: Min Sepúlvida Pertence; Tribunal Pleno, j. 05/04/1990, DJ 29/06/1990.
} 
impossibilidade de concessão de liminares. No entanto, conforme bem adverte Ricardo Perlingeiro Mendes da Silva, "a constitucionalidade dessas vedações deve ser verificada caso a caso."143

Ademais, cumpre ressaltar que o STF também analisou a constitucionalidade do artigo $1^{\circ}$ da Lei 9494/97, que regulava antes do artigo $7^{\circ} \S$ $5^{\circ}$ da lei 12.016/09 muitas restrições à antecipação de tutela em face do Poder Público.

Em sessão realizada no dia $1^{\circ}$ de outubro de 2008, o Plenário do STF julgou definitivamente a ADC 4, para, confirmando a liminar concedida, para afirmar a constitucionalidade do artigo $1^{\circ}$ da Lei 9.494/97.

E m e $\mathrm{n} t$ a: Ação Declaratória De Constitucionalidade - Processo Objetivo De Controle Normativo Abstrato - Natureza Dúplice Desse Instrumento De Fiscalização Concentrada De Constitucionalidade - Possibilidade JurídicoProcessual De Concessão De Medida Cautelar Em Sede De Ação Declaratória De Constitucionalidade - Inerência Do Poder Geral De Cautela Em Relação À Atividade Jurisdicional - Caráter Instrumental Do Provimento Cautelar Cuja Função Básica Consiste Em Conferir Utilidade E Assegurar Efetividade Ao Julgamento Final A Ser Ulteriormente Proferido No Processo De Controle Normativo Abstrato - Importância Do Controle Jurisdicional Da Razoabilidade Das Leis Restritivas Do Poder Cautelar Deferido Aos Juízes E Tribunais Inocorrência De Qualquer Ofensa, Por Parte Da Lei No 9.494/97 (Art. 1º), Aos Postulados Da Proporcionalidade E Da Razoabilidade - Legitimidade Das Restrições Estabelecidas Em Referida Norma Legal E Justificadas Por Razões De Interesse Público - Ausência De Vulneração À Plenitude Da Jurisdição E À Cláusula De Proteção Judicial Efetiva - Garantia De Pleno Acesso À Jurisdição Do Estado Não Comprometida Pela Cláusula Restritiva Inscrita No Preceito Legal Disciplinador Da Tutela Antecipatória Em Processos Contra A Fazenda Pública Outorga De Definitividade Ao Provimento Cautelar Que Se Deferiu, Liminarmente, Na Presente Causa - Ação Declaratória De Constitucionalidade Julgada Procedente Para Confirmar, Com Efeito Vinculante E Eficácia Geral E "Ex Tunc", A Inteira Validade Jurídico-Constitucional Do Art. $1^{\circ}$ da Lei 9.494, de 10/09/1997, Que "Disciplina A Aplicação Da Tutela Antecipada Contra A Fazenda Pública" 144

Leonardo Carneiro da Cunha afirma que:

Embora tenha reconhecido a constitucionalidade das restrições e vedações à concessão da tutela antecipada contra o Poder Público, o STF vem conferindo interpretação restritiva ao referido dispositivo, diminuindo seu âmbito de abrangência para negar reclamações constitucionais em algumas hipóteses em que

\footnotetext{
${ }^{143}$ SILVA, Ricardo Perlingeiro Mendes da. Execução contra a Fazenda Pública. São Paulo: Malheiros, 1999, p. 148.

${ }^{144}$ Idem, nota n. 140.
} 
lhe parece cabível a medida antecipatória, mesmo para determinar o pagamento de soma em dinheiro. ${ }^{145}$

Afirma também o autor que se a tutela antecipada não for concedida para impor o pagamento de vantagem, mas tal pagamento for realizado como consequência da medida antecipatória, a hipótese não se encaixaria na proibição do artigo $1^{\circ}$ da Lei 9494/97, não havendo, portanto, ofensa à decisão proferida na ADC $4 .{ }^{146}$

O Superior Tribunal de Justiça tem firme jurisprudência a respeito do tema, conforme se observa pela transcrição de seu julgado.

Processual Civil. Embargos declaratórios. Administrativo. Mandado de segurança. Concurso público. Nomeação e posse em cargo público. Execução provisória. Inexistência de afronta à lei 9.494/97. Embargos Acolhidos Sem Efeito Modificativo.

1. A vedação contida na Lei 9.494/97 em relação à concessão de antecipação de tutela contra a Fazenda Pública nos casos de aumento ou extensão de vantagens a servidor público não se aplica nas hipóteses em que o autor busca sua nomeação e posse em cargo púbico, razão da sua aprovação em concurso público. Precedentes do STJ.

2. Possibilidade da execução provisória, na hipótese dos autos, para cumprimento da determinação do acórdão embargado. ${ }^{147}$

A Suprema Corte também tem se manifestado no mesmo sentido, conferindo interpretação restritiva aos dispositivos legais que proíbem a concessão de tutela de urgência em face do Poder Público. Nesse sentido, decidiu serem inaplicáveis essas regras excepcionais quando se tratar de nomeação, conforme podemos observar com o que foi decidido nos autos da Reclamação n. 9.270/SP:

Agravo regimental em reclamação constitucional. Sentença que determina a imediata nomeação e posse em cargo público. Ausência de desrespeito ao acórdão do supremo tribunal federal na ADC 4.

(...)

2. A reclassificação ou equiparação de servidores públicos e a concessão de aumento ou extensão de vantagens (art. $5^{\circ}$ da Lei 4.348/1964) cuidam da específica situação em que um servidor público postula tais direitos em Juízo. O mesmo vale

145 CUNHA, Leonardo José Carneiro. A Fazenda Pública em Juízo. 11. ed. São Paulo: Dialética., 2010. p. 292.

146 BRASIL. Jurisprudência. Supremo Tribunal Federal. Ação Declaratória de Constitucionalidade $\mathbf{n}^{\mathbf{0}}$ 4. Requerentes: Presidente da República, Mesa do Senado Federal e Mesa da Câmara dos Deputados. Relator: Min. SYDNEY SANCHES, Relator p/ Acórdão: Min. Celso de Mello. Dj, 15 out. 2008. Disponível em: <http://www.stf.jus.br/portal/jurisprudencia /listarJurisprudencia $\quad$.asp $\quad ? \quad$ s1=\%28ADC\%24 $\% 2 \mathrm{ESCLA} \% 2 \mathrm{E}+\mathrm{E}+4 \% 2 \mathrm{ENUME} \% 2 \mathrm{E} \% 29+\mathrm{OU}+\% 28 \mathrm{ADC} \% 2 \mathrm{EACMS} \% 2 \mathrm{E}+\mathrm{ADJ} 2+$ 4\%2EACMS\%2E\%29\&base=baseAcordaos\&url= >. Acesso em: 24 nov. 2018.

147 BRASIL. Jurisprudência. Supremo Tribunal de Justiça. EDcl nos EDcl no RMS 27.311/AM, rel. Min. Jorge Mussi, DJe de 14/02/2014. 
para o pagamento de vencimentos e vantagens pecuniárias de que trata o $\S 4^{\circ}$ do art. $1^{\circ}$ da Lei 5.021/1966.

3. A determinação de que candidatos sejam nomeados e empossados em cargo público não ofende a decisão do Supremo Tribunal Federal na ADC.

4. A postulação para ingresso nos quadros funcionais do Estado diz respeito ao direito de acesso aos cargos, empregos ou funções de natureza pública. Direito expressamente assegurado pelo inciso II do art. 37 da Constituição Federal e consistente na instauração de vínculo jurídico então inexistente. Direito, portanto, à formação de um liame jurídico a que o Poder Público, no caso, resiste. Já os demais direitos subjetivos, versados na $\mathrm{ADC} 4$, esses dizem respeito a relação jurídica preexistente, ou, se se prefere, dizem respeito a institutos jurídicos que tem por pressuposto de incidência uma anterior relação jurídica entre o servidor público e a pessoa do Estado. Relação jurídica em nenhum momento posta em causa quanto à juridicidade de sua formação, ou de sua continuidade. ${ }^{148}$

Portanto, a concessão de tutela antecipada para assegurar a nomeação de candidato aprovado em concurso público, sem concessão de efeito financeiro pretérito, conforme entendimento pacificado no âmbito do STF, não atenta contra a decisão proferida na ADC 4.

Outrossim, não haverá ofensa à decisão proferida na ADC 4 se a decisão concessiva da tutela antecipada se apoiar em entendimento já consolidado no STF, porquanto deve-se prestigiar a observância aos precedentes obrigatórios. Se a Corte Suprema já firmou entendimento num determinado sentindo, deve a Administração Pública observá-lo, sob pena de vulnerar à isonomia e a segurança jurídica.

O STJ também tem afastado as normas proibitivas da tutela provisória contra o Poder Público em casos excepcionais, que revelem o estado de necessidade e a exigência de preservação da vida humana, conforme se observa pelos julgados abaixo colacionados.

Ementa Processual Civil - Ação De Indenização - Transplante De Rim Malsucedido - Tutela Antecipada - Apelação Recebida em Ambos os Efeitos Excepcionalidade dos Efeitos da Antecipação para Garantir Pagamento de Pensão Indispensável À Sobrevivência do Apelado - Inapllcabilidade, No caso, do Artigo $1^{\circ}$ da Lei ${ }^{\circ} 9.494$ de 1.997.

A Lei $n^{\circ}$ 9.494/97 (artigo $1^{\circ}$ ) deve ser interpretada de forma restritiva, não cabendo sua aplicação em hipótese especialíssima, na qual resta caracterizado o estado de necessidade e a exigência de preservação da vida humana, sendo de se impor a antecipação da tutela, no caso, para garantir ao apelado o tratamento

\footnotetext{
148 BRASIL. Jurisprudência. Supremo Tribunal Federal. Recl. n. 9.270/SP, rel. Min. Ayres de
} Brito, julgado em 24/03/2011. 
necessário à sua sobrevivência. Decisão consonante com precedentes jurisprudenciais do STJ. Recurso improvido. ${ }^{149}$

Ementa: previdenciário. Antecipação de Tutela contra a Fazenda Pública. Vedação. Lei 9.494/97. Exceção. Estado de Necessidade. Sobrevivência. Jurisdicionado. Análise de seus pressupostos. Reexame de provas. Súmula 07/STJ.

1. Apesar de o egrégio Supremo Tribunal Federal ter firmado entendimento, quando do julgamento em plenário da medida liminar na ADC 4, no sentido da impossibilidade da concessão de tutela em face da Fazenda Pública, o art. $1^{\circ}$ da Lei 9.494/97 deve ser interpretado restritivamente, não incidindo em situações especialíssimas, nas quais restam evidentes o estado de necessidade, a exigência de preservação da vida humana e de sobrevivência do jurisdicionado. Precedentes.

2. A verificação da ocorrência ou não dos requisitos necessários à concessão de antecipação de tutela, demanda revolvimento de matéria fático-probatória, vedado em sede de especial, ut verbete da súmula 07/STJ.

\section{Recurso não conhecido. ${ }^{150}$}

Parte da doutrina entende que a imposição de trânsito em julgado conferida por emenda constitucional (art. 100, $\S 5^{\circ}, \mathrm{CF}$ ), para a expedição de precatório, afronta o direito fundamental à tutela preventiva e efetiva, afirmando que não se pode confundir trânsito em julgado com coisa julgada.

Nesse sentido, afirma Ana Paula Sanzovo de Almeida Prado: "A antecipação provisória dos efeitos da tutela contra o Poder Público, para pagar quantia, determinada por decisão interlocutória (cognição sumária e inapta a fazer coisa julgada) é possível, corolário do direito de acesso à justiça."151

Podemos encontrar decisões no âmbito do STJ e de nossa Corte Suprema nesse sentido. ${ }^{152}$

No julgamento do REsp n. 834.678-PR, há imposição de pagamento imediato de pensão provisória de cunho indenizatório pelo município, para custeio de despesas médicas e terapêuticas de menor, acometido de encefalopatia grave e irreversível devido à vacina aplicada em posta de saúde;

Na STA 223 AgR/PE, o STF determinou que Estado de Pernambuco pague despesas necessárias à realização de cirurgia de implante de marcapasso

\footnotetext{
149 BRASIL. Jurisprudência. Acórdão unânime da Primeira Turma do Superior Tribunal de Justiça, REsp n. 275.649-SP, rel. Ministro Garcia Vieira j.7/08/2001.

${ }^{150}$ BRASIL. Jurisprudência. Acórdão unânime da Sexta Turma do STJ, REsp 420.954-SC, rel Min. Fernando Gonçalves, j. 22/10/2002.

${ }^{151}$ PRADO, Ana Paula Sanzovo de Almeida. Pode haver estabilidade de tutela satisfativa antecedente contra a Fazenda Pública? Publicações da Escola AGU. Disponível em: https://seer.agu.gov.br/index.php/EAGU/article/view/22 92>. Acesso em: 26 dez. 2018.

${ }_{152}$ DIDIER JR., Fredie; BRAGA, Paula Sarno; OLIVEIRA, Rafael Alexandria de. Curso de
}

Direito Processual Civil. 11. ed. Salvador: Jus Podivm, 2016. v. 2. p. 652. 
diafragmático muscular em benefício do autor, tetraplégico em razão de assalto ocorrido em via pública, para que seja imediatamente devolvida a capacidade de respirar independentemente de respirador mecânico.

Como é sabido, quando não houver a exigência de expedição de precatório, como por exemplo, para as obrigações de fazer, não fazer e entrega de coisa em face do Poder Público, não há qualquer óbice à concessão da tutela provisória. No entanto, devemos ressaltar que existem algumas particularidades, como em ação possessória contra o Poder Público, em que não é possível a concessão de tutela provisória sem sua prévia oitiva (art. 562, p. único, CPC). 


\section{5 \\ Restrições à concessão da tutela provisória em face do Poder Público}

\section{1 \\ Divergência doutrinária acerca da constitucionalidade das regras que vedam a concessão de provimento de urgência em face de entidades integrantes da Administração Pública}

Como se viu, nosso ordenamento jurídico preconiza regras que vedam a concessão de tutela de urgência contra a Fazenda Pública. No entanto, parte da doutrina entende que tais restrições são inconstitucionais, por vulnerarem a garantia da inafastabilidade do controle jurisdicional. Nesse sentido, podemos citar Cassio Scarpinella Bueno ${ }^{153}$ e Luís Otavio Sequeira de Castro. ${ }^{154}$

Por sua vez, há quem defenda não haver inconstitucionalidade, uma vez que essas regras não estariam rigorosamente vedando ou restringindo a concessão da liminar. $\mathrm{Na}$ realidade, tais normas estariam a retratar hipóteses em que não se fariam presentes os requisitos para a concessão da liminar, seja em razão da irreversibilidade, seja porque ausente o periculum in mora.

Segundo Francisco Cavalcanti,

Inconstitucional seria a criação de limitações, restringindo o princípio da plenitude da tutela jurisdicional. Tal ocorreria, caso a restrição na concessão de liminares atingisse, inclusive, aquelas representadas por medidas conservativas e assecuratórias, ensejando o perecimento do direito.

(...)

Essa lei não impediu a concessão de medidas acautelatórias no sentido de obstar, exempli gatia, a alienação forçada de bem apreendido ou a sua conservação na área de importação. Por outro lado, a restrição legal não implica proibição de liberação de bens importados, em hipóteses nas quais a lide versa apenas sobre o valor dos tributos e outras exações incidentes sobre a operação. Nessas hipóteses, a concessão de liminar é possível, desde que condicionada à contracautela, representada pelo depósito em dinheiro da quantia objeto de discussão, ou, excepcionalmente, mediante caução idônea, para resguardar a Fazenda Pública, na

153 BUENO, Cassio Scarpinella. A Nova Lei do Mandado do Segurança. São Paulo: Saraiva, 2009, n. 17, p. 45.

${ }^{154}$ CASTRO, Luís Otávio Sequeira de. Comentários à Nova Lei do Mandado de Segurança (em coautoria com Luiz Manoel Gomes Junior, Luana pedrosa de Figueiredo Cruz, Rogério Favreto e Sidney Palharini Júnior). São Paulo: Revista dos Tribunais, 2009. p. 90-91. 
hipótese de não acolhimento da pretensão. Essa linha corresponde a um ponto de equilíbrio entre o interesse privado e o interesse da Administração Pública. ${ }^{155}$

Em seguida prossegue ao afirmar que:

Trata-se de restrições que não violam o princípio da plenitude da tutela jurisdicional, porque visam, os procedimentos referidos, acréscimos, plus, a serem agregados à remuneração de servidores. Não há nelas, periculum in mora, considerando que o servidor não tem prejuízo, no tocante à remuneração então percebida, e, por outro lado, considerando a condição de solvente da Fazenda Pública, que faz desaparecer o risco de inexequibilidade do julgado favorável. Não se pode também esquecer, que face à natureza alimentar dos pagamentos de remuneração, a restituição na hipótese de improcedência não ocorreria ou se tal ocorresse, seria de modo parcelado, observado os limites legais (cf. a lei $8.112 / 90) .{ }^{156}$

De acordo com essa corrente doutrinária, o legislador, em exame prévio, já descartou a possibilidade de concessão de liminar para situações em que não se revela presente o risco de grave lesão ou de difícil reparação, ou porque a medida se revela irreversível.

Se o servidor público, por exemplo, pretende agregar valores a seus vencimentos, não está presente o periculum in mora, necessário para a concessão da medida. Diversamente é a situação do servidor público que tenha suprimida uma vantagem de sua remuneração. Nesse caso, por se tratar de restauração da vantagem, caberá a concessão da medida de urgência, porquanto encontra-se presente o risco de dano irreparável ou de difícil reparação.

Nos termos da jurisprudência do STJ, a vedação para a concessão de liminar destinada à liberação de bens e de mercadorias justifica-se, em princípio pelo risco de irreversibilidade da medida, pois o desembaraço antecipado das mercadorias pode impedir eventual cominação do perdimento. ${ }^{157}$

Assim, deve haver uma ponderação de interesses no momento da resolução do caso concreto. Se houver aparente conduta criminosa ou risco para a coletividade, para o meio ambiente, para a saúde, isto é, para o interesse público, sendo possivelmente irreversível a medida, nesse caso, há de prevalecer a vedação legal. Diversamente, se ausente quaisquer dessas situações, a apreensão da mercadoria caracterizar-se-á como meio coercitivo indireto de cobrança de

${ }^{155}$ CAVALCANTI, Francisco. O novo regime jurídico do mandado de segurança. São Paulo: MP, 2009, n. 5.31, p. 114-115.

${ }^{156}$ Idem, Ibidem, n. 5.32, p. 115-116.

${ }^{157}$ BRASIL. Jurisprudência. Acórdão unânime da $2^{\mathbf{a}}$ Turma do STJ, REsp 1.184.720/DF, rel. Min. Mauro Campbell Marques, j. 5/08/2010, DJe de 1/09/2010. 
tributo, devendo então prevalecer a concessão da medida liminar, pois referido ato, segundo o STJ ,configura sanção política, que se caracteriza pela utilização de meios de coerção indireta que impeçam ou dificultem o exercício de atividade econômica para constranger o contribuinte ao pagamento de tributos em atraso. Isto porque, devido um tributo, o Estado dispõe da execução fiscal para compelir os seus devedores a realizar o pagamento destes, a fim de prestigiar os princípios do contraditório, da ampla defesa e do devido processo legal.

Assim, devido um tributo, cabe ao ente fazendário constituir o crédito tributário por meio do lançamento tributário e promover a cobrança judicial, por meio dos executivos fiscais, não sendo legítima a adoção de medidas restritivas ao contribuinte como forma indireta de cobrança.

A jurisprudência é farta de decisões que repelem a adoção de meios coercitivos indiretos de cobrança, podendo exemplificar com o teor dos enunciados 70, 323, 547, todos da súmula de jurisprudência do STF, cujas transcrições se impõem:

Súmula 70. É inadmissível a interdição de estabelecimento como meio coercitivo para cobrança de tributo.

Súmula 323. É inadmissível a apreensão de mercadorias como meio coercitivo para pagamento de tributos.

Súmula 547. Não é lícito à autoridade proibir que o contribuinte em débito adquira estampilhas, despache mercadorias nas alfândegas e exerça suas atividades profissionais. ${ }^{158}$

Portanto, caberá a parte autora demonstrar a presença dos requisitos para a concessão da medida liminar. Se restar demonstrada, deverá ser concedida a medida de urgência, a fim de prestigiar o princípio da efetividade e inafastabilidade do controle jurisdicional. Diversamente, se não demonstrada a situação de excepcionalidade, impõe-se negar o pedido de concessão, em consonância com as previsões legais que vedam o seu deferimento, prestigiando nesse caso, o interesse público.

Para Hélio do Valle Pereira, "o legislador estaria, na verdade, incentivando o juiz a ter redobrados escrúpulos na concessão da medida de urgência,

158 BRASIL. Jurisprudência. Súmula 547. Supremo Tribunal Federal. Disponível em: < www.stf.jus.br/portal/jurisprudencia/menuSumarioSumulas.asp?sumula=2201 >. Acesso em: 10 dez. 2018. 
eliminando abusos e exageros na concessão de liminares contra o Poder Público." ${ }^{159}$

Tais restrições legais, segundo ele, "não vingarão, entretanto, se no caso concreto, de forma fundamentada, aparecerem impedientes à proteção jurisdicional do direito." 160

Eduardo José Fonseca da Costa entende que as mencionadas disposições legais não impedem a concessão de liminares contra o Poder Público, mas sim, enrijecem os pressupostos para o deferimento de providências de urgência contra a Fazenda Pública, exigindo um periculum in mora extremado.

Nas palavras do autor: As liminares em tais casos podem ser concedidas, desde que se configure na espécie, uma hipótese excepcional de extremo perigo. Do contrário, não deve ser concedida a medida. ${ }^{161}$

Leonardo Carneiro da Cunha, por sua vez, entende que tais restrições reclamam exegese restritiva, somente sendo vedada a concessão de liminar nos casos expressamente indicados no dispositivo legal.

Entendemos que operador jurídico deverá ser bastante cuidadoso nesses casos, para que se verifique se a regra especial criada em favor da pessoa jurídica de direito público promove a igualdade material, pois apesar de o legislador já ter efetuado previamente um juízo de valor entre os interesses colidentes, é preciso analisar o benefício criado à luz do elemento que gera diferenciação em favor do Poder Público, com respaldo na razoabilidade, uma vez que se trata de parâmetro da constitucionalidade das leis que criam desigualdades entre os sujeitos do processo.

Vale trazer aqui a lição de Celso Antônio Bandeira de Mello:

(..) Importa que exista mais que uma correlação lógica abstrata entre o fator diferencial e a diferenciação consequente. Exige-se, ainda, haja uma correlação lógica concreta, ou seja, aferida em função dos interesses abrigados no direito positivo constitucional. E isto se traduz na consonância ou dissonância dela com as finalidades reconhecidas como valiosas na Constituição. ${ }^{162}$

\footnotetext{
159 PEREIRA, Hélio do Valle. O novo mandado de segurança: comentários à Lei 12016, de 7/08/2009. Florianópolis: Conceito Editorial, 2010, p. 96.

160 Ibidem, p. 97.

${ }^{161}$ ALVIM, Eduardo Arruda (Coord.). As leis impeditivas de liminar realmente impedem? O novo mandado de segurança: estudos sobre a Lei 12.016/09. Belo Horizonte: Fórum, 2010, p. $159-168$.

${ }^{162}$ MELLO, C. A. B. de., op. cit., p. 22.
} 
Portanto, entendemos que a previsão abstrata de vedação ao deferimento de medidas liminares não representa ofensa ao princípio da igualdade, caso haja fundamento razoável à distinção de tratamento, ou ao acesso à justiça, se isso não obstaculizar a obtenção de uma prestação jurisdicional justa. Assim, propomos uma avaliação casuística de cada situação, a fim de se constatar que a vedação da tutela de urgência em face do poder público não vulnera o objetivo do acesso à justiça, qual seja o de entregar ao jurisdicionado uma prestação justa ao final da relação processual. 


\section{6 \\ A estabilização da tutela antecipada antecedente e a Fazenda Pública}

Há acirrada divergência doutrinária acerca da possibilidade de aplicação do instituto da estabilização da tutela antecipada em face da Fazenda Pública.

Desde já, convém advertir que o Fórum permanente de Processualistas Civis editou o enunciado 582 prevendo que: “Cabe estabilização da tutela antecipada antecedente contra a Fazenda Pública."163

Conforme já mencionamos em tópico anterior, a estabilização da tutela antecipada é a possibilidade de encerramento da lide no plano da urgência, nas hipóteses em que o réu não oferecer resistência contra a liminar concedida. Assim, apesar de se tratar de decisão proferida em sede de cognição sumária, o processo é extinto, muito embora sem que haja formação da coisa julgada. Essa técnica processual prestigia a garantia fundamental à tutela jurisdicional justa, efetiva e tempestiva, nos termos dos incisos XXXV, LIV, LXXVII do artigo $5^{\circ}$ da $\mathrm{CRFB} / 88^{164}$. A possibilidade de estabilização da tutela rompe com o dogma da cognição plena.

A necessidade de se desmistificar o dogma da universalidade do procedimento ordinário de cognição, da sentença e da coisa julgada já era, há muito, apontada por Ada Pellegrini Grinover:

Agora é hora de desmitificar, sempre que necessário, os dogmas da universalidade do procedimento ordinário de cognição, da sentença e da coisa julgada, que não podem mais ser considerados como a única técnica processual para a solução jurisdicional das controvérsias. ${ }^{165}$

Para que ocorra a estabilização dos efeitos da tutela antecipada antecedente, nos termos já mencionados anteriormente, há a necessidade de observância dos requisitos preconizados nos artigos 303 e 304 do CPC/15, isto é, o autor deverá se

\footnotetext{
163 PEIXOTO, Ravi. (Coord.) Enunciados do Fórum Permanente de Processualistas civis EFPPC - Comentados. 1. ed. Salvador: JusPodivm, 2018.

${ }^{164}$ Idem, nota n. 9.

165 GRINOVER, Ada Pellegrini. Tutela jurisdicional diferenciada: a antecipação e sua estabilização. Revista de Processo, São Paulo, a. 30, v. 121, 2005. p. 35.
} 
manifestar expressamente, optando por esse procedimento, nos termos do artigo $3035^{\circ}$, deve haver deferimento da medida e é imprescindível a ausência de manifestação por parte do réu. No entanto, em razão de a Fazenda Pública apresentar um regime diferenciado, passa-se a analisar se existe óbice à aplicação desse instituto em face desta.

\section{1 Peculiaridades que envolvem a atuação da Fazenda Pública em Juízo}

A atuação da Fazenda Pública em juízo, em razão do interesse público por ela tutelado, ostenta peculiaridades que as diferencia dos demais jurisdicionados. Isto porque, além de sua atuação se dar em prol da coletividade, há uma série de dificuldades estruturais inerentes ao serviço público que acaba por repercutir sobremaneira em sua atuação em juízo.

Por essa razão o ordenamento jurídico, conforme mencionado, lhe confere prerrogativas, e é com respaldo nestas, em especial na remessa necessária e na indisponibilidade do interesse público, que se deve compreender a estabilização da tutela antecipada em face da Fazenda Pública.

Outra questão trazida pela doutrina em relação a esse ponto é a afirmação de que existe um microssistema de tutela de direitos pela técnica monitória. Isto porque, requerida a tutela antecipada antecedente, a decisão que a defere pode estabilizar-se, nos termos do artigo 304, havendo nesse caso uma monitorização do procedimento, ou seja, essa decisão plasmada em cognição sumária é proferida, invertendo-se o ônus da iniciativa do contraditório, concretizando desta feita, a técnica monitória.

Assim, a técnica monitória configura um instrumento de tutela jurisdicional diferenciada, tendo por escopo a efetividade do processo, abreviando a formação do título executivo, pela inversão da iniciativa do contraditório, transferindo para o réu o ônus da instauração do processo de cognição exauriente, assim como ocorre na técnica da estabilização da tutela antecipada antecedente, conforme dispõe os artigos 303 e 304 do CPC/15. 


\section{2 \\ Os óbices levantados pela doutrina à estabilização da tutela antecipada em face da Fazenda Pública}

Um dos principais argumentos levantados pela doutrina para o fim de obstar o reconhecimento da estabilização da tutela em face do Poder Público é a indisponibilidade do interesse público, em razão da impossibilidade de imposição do efeito material da revelia, por envolver interesses indisponíveis, conforme preconizado no artigo 345 , II do CPC/15.

Nesse sentido, podemos citar Marco Antonio Rodrigues. O autor entende que esse instituto da estabilização da tutela de urgência não pode ser manejado em face de pessoas jurídicas de direito público. ${ }^{166}$

Isto porque, a ausência de contestação a uma demanda, via de regra acarreta a revelia, com o seu consequente efeito de presunção de veracidade das alegações do autor, nos termos do artigo 344 do CPC. Ocorre que a Fazenda Pública não fica sujeita a tal efeito material, considerando que se trata de direitos indisponíveis, na forma do artigo 345, II, do CPC.

De acordo com o artigo 392 do CPC, a admissão em juízo de fatos relativos a direitos indisponíveis não vale como confissão. $\mathrm{O} \S 1^{\circ}$ deste artigo dispõe que a confissão será ineficaz se feita por quem não for capaz de dispor do direito a que se referem os fatos confessados. Assim, o advogado público, a menos que autorizado a confessar, não pode produzir confissão dotada de eficácia. Nos termos do artigo 341, I do CPC, as alegações de fato feitas pelo autor, ainda que não impugnadas, não são presumidas verdadeiras quando não for admissível a seu respeito a confissão. Desse modo, a ausência de contestação de fatos relativos a direitos indisponíveis, como é o caso de ausência de contestação atribuída ao advogado público, não torna os fatos incontroversos. ${ }^{167}$

Sob tal perspectiva, a indisponibilidade do interesse do público seria elemento a ser considerado como suficiente para obstar a estabilização.

No entanto, não há consenso doutrinário. De outro lado, para aqueles que admitem a estabilização da tutela antecipada, refutam esse argumento aduzindo que nem sempre atender o interesse público, significa defender a todo custo um direito que se afirma ser "indisponível", uma vez que o Estado deve em determinadas situações e sob certos limites, reconhecer e cumprir

\footnotetext{
${ }^{166}$ RODRIGUeS, Marco Antônio. A Fazenda Pública no Direito Processual Civil. 2. ed. São Paulo: Atlas, 2016. p. 109-110.

${ }^{167}$ Idem.
} 
espontaneamente direitos alheios. Sob esse viés, afirmam se tratar de garantia do administrado, revelando a necessária observância dos princípios da legalidade administrativa e da eficiência.

Há um segundo óbice à estabilização da tutela antecipada apontado por alguns autores, qual seja, a remessa necessária.

Conforme já se mencionou, alguns autores vêm defendendo de lege lata, a aplicação da técnica monitória no procedimento para a estabilização da tutela antecipada. Assim, com respaldo no entendimento desses autores, haveria dois procedimentos no $\mathrm{CPC} / 15$ que se valem da técnica monitória, do qual a técnica da estabilização seria um desses.

Apesar da questão acerca do cabimento da técnica monitória em face da Fazenda Pública já ter sido alvo de debates doutrinários e jurisprudenciais, no entanto, esta já havia sido pacificada ainda sob a égide do $\mathrm{CPC} / 73$, por meio do enunciado 339 da Súmula da Jurisprudência do STJ: "É cabível ação monitória contra a Fazenda Pública"

Portanto, conforme pacificado pela jurisprudência, não há a priori, incompatibilidade entre o procedimento monitório e a Fazenda Pública.

Nesse sentido, adverte Ada Pellegrini Grinover:

Não vejo nenhuma incompatibilidade entre um procedimento que visa exclusivamente a abreviar o caminho para a formação de um título executivo e a execução deste título executivo contra a Fazenda Pública, que virá depois. O que se consegue, através do procedimento monitório, nada mais é do que o título executivo. Se posso fazer valer um título contra a Fazenda Pública, pelas formas próprias, adequadas a execução contra a Fazenda Pública, também posso constituí-lo de forma abreviada contra a mesma Fazenda Pública. Sem dúvida nenhuma, há documentos escritos que podem ser utilizados e que não tem força de título executivo contra a Fazenda Pública, como, v.g., o empenho. Tratar-se-á somente de observar as prerrogativas da Fazenda Pública no procedimento monitório, benefício de prazo para embargar (contestar) e talvez, a garantia do duplo grau quando a sentença condicional se consolidar. ${ }^{168}$

Nesse mesmo sentido, assevera Luiz Guilherme Marinoni, Sérgio Cruz Arenhart e Daniel Mitidiero:

Pouco importa a natureza do devedor, ele estará sempre sujeito à ação monitória. Discutiu-se, no passado, se seria cabível a ação monitória contra a Fazenda Pública. A discussão se centrava na consequência dessa admissão, que seria a possibilidade de execução de título (que não fosse propriamente uma sentença) contra o Poder Público. A questão, porém, se tornou pacífica na ótica da

${ }^{168}$ GRINOVER, Ada Pellegrini. Da ação monitória em face da Fazenda Pública. Consulex, Rio de Janeiro, ano 1, n. 6, [20__?]. 
jurisprudência, no sentido de admitir a ação monitória contra a Fazenda Pública ${ }^{169}$. E essa mesma solução foi abraçada na legislação atual, que expressamente admite a ação monitória contra a Fazenda Pública (art. 700, § $6^{\circ}$ ), ainda que sujeite essa demanda a um regime especial, adaptado às prerrogativas desse ente (art. 700, § $\left.4^{\circ}\right) .{ }^{170}$

Dessa forma, sob essa perspectiva, não haveria qualquer óbice para aplicação da técnica monitória em face da Fazenda Pública.

No entanto, apesar de lei e a jurisprudência afirmar o cabimento da ação monitória em face da Fazenda Pública, fato é que nem a lei nem a jurisprudência afastaram a necessidade prévia da remessa necessária em face dessa decisão. Ao revés, o $\S 4^{\circ}$ do art. 701 do $\mathrm{CPC}$ do $\mathrm{CPC} / 15$ preconiza expressamente a necessidade de remessa necessária nas hipóteses de não oposição dos embargos pela Fazenda Pública, o que acaba por repercutir na incidência do efeito monitório no caso da estabilização da tutela antecipada.

Dessa forma, apesar de não existir impedimento legal à incidência da técnica monitória em face do Poder Público, a lei exige o reexame necessário, conforme previsão expressa no artigo $701 \S 4^{\circ}$ do CPC.

Para melhor compreensão, transcreve-se as lições de Eduardo Talamini.

Assevera o autor:

O CPC/15 disciplinou o tema da estabilização da tutela expressamente no âmbito da ação monitória. No tocante à Fazenda Pública, há a supressão do principal efeito monitório, pois se não houver embargos ao mandado, haverá reexame necessário (art.701 $4^{\circ}$ ). Logo, não se constituirá de pleno direito o título executivo. O tribunal que seria competente para o recurso, revisará a decisão concessiva da tutela monitória. Se é assim na monitória, torna-se sistematicamente muito difícil, se não inviável, reconhecer a incidência do efeito monitório no caso de falta de recurso da Fazenda contra tutela antecipada antecedente. ${ }^{171}$

Prossegue o processualista:

Há ainda um segundo óbice, de caráter objetivo. Se a posição jurídico-material atingida na tutela antecipada tem caráter indisponível, não parece possível que ela possa ser neutralizada, por tempo indeterminado (e talvez definitivamente) pelo fenômeno da estabilização. Imagine-se o caso em que se obtém uma tutela antecipada antecedente para sustar os efeitos do ato de exoneração de um servidor,

\footnotetext{
169 BRASIL. Jurisprudência. Supremo Tribunal de Justiça. REsp. 434571, $1^{\text {a }}$ S., rel. Min. Luiz Fux, DJU 20.03.2006.

${ }^{170}$ MARINONI, L. G.; ARENHART, S. C.; MITIDIERO, D., op. cit., p. 233.

171 TALAMINI, Eduardo. Ainda a estabilização da tutela antecipada. In: Migalhas, correlação entre estabilização da tutela, a ação monitória e a fazenda pública 1/04/2016.
} 
por falta grave. Não seria razoável estabilizar-se a suspensão da eficácia do ato sem cognição exauriente dos seus fundamentos de legitimidade. ${ }^{172}$

Assim, para o referido processualista, pela adoção de um regime único, não deveria haver dispensa da remessa necessária para estabilização da tutela antecipada antecedente em face da Fazenda Pública, por força do artigo $704 \S 4^{\circ}$ do CPC/15, apesar da ausência de previsão legal nesse sentido.

Nesse mesmo sentido, podemos citar Eduardo José da Fonseca. Apesar de o autor admitir a estabilização da tutela antecipada em face da Fazenda Pública, afirma ser preciso proceder à remessa necessária, a fim de que o tribunal confirme a decisão e se possa, efetivamente ter a estabilização. ${ }^{173}$

Para ele, a tutela de urgência satisfativa antecedente pode ser proposta contra a Fazenda Pública, estando a decisão apta a estabilizar-se. ${ }^{174}$

Por outro lado, há autores que entendem que o só fato de haver previsão expressa da remessa necessária para a ação monitória, não leva a conclusão de que há também necessidade de sua aplicação ao procedimento de estabilização.

Entendendo pelo descabimento da remessa necessária como condição para estabilização Heitor Vitor Mendonça:

De todos os problemas propostos, talvez seja este o de mais fácil solução. A resposta à questão acerca da possibilidade de a decisão estabilizada sujeitar-se à remessa necessária é evidentemente negativa, a começar pelo fato de que o art. 496 do novo CPC delimita o cabimento da remessa necessária para a "sentença (...)". Ora, a decisão que antecipa tutela não é sentença, à luz do conceito acolhido pelo art. 203, $\S 1^{\circ}$, ao passo que a decisão que extingue o processo nos termos do art. $304, \S 1^{\circ}$, embora se amolde ao conceito positivado de sentença, não pode ser considerada propriamente proferida "contra" a Fazenda Pública - ré. ${ }^{175}$

Leonardo Carneiro da Cunha adverte que existem vários casos em que a tutela de urgência é vedada contra o poder público, como se viu, e naqueles casos, não será possível a tutela de urgência, nem a sua estabilização.

Nas palavras do jurista:

Nos casos em que se permite a tutela de urgência contra o Poder Público, é possível haver a tutela satisfativa antecedente, com a consequente estabilização. Não se

\footnotetext{
172 Idem.

173 COSTA, Eduardo José da Fonseca. Comentários ao art. 304. In: STRECK, Lênio Luiz; NUNES, Dierle; CUNHA, Leonardo Carneiro da. (Orgs.) Comentários ao Código de Processo Civil. São Paulo: Saraiva, 2016, no prelo.

${ }^{174}$ Idem.

${ }^{175}$ MENDONÇA, H. V., op. cit., p. 315.
} 
permite estabilização para antecipar condenação judicial e permitir a imediata expedição de precatório ou de requisição de pequeno valor. Isso porque a expedição de precatório ou de requisição de pequeno valor exige prévia coisa julgada. Nesse sentido, tem-se uma incompatibilidade ente a lógica do procedimento, com a necessidade de prévia inscrição em precatório. ${ }^{176}$

Apesar de se tratar de temática polêmica, entendemos que o procedimento de estabilização da tutela não se coaduna com as peculiaridades ostentadas pela Fazenda Pública quando de sua atuação em juízo. No entanto, caso se admita por hipótese, a concessão da tutela antecipada antecedente em face da Fazenda Pública, fato é que a estabilização torna indiscutível uma situação desfavorável para a Fazenda Pública e, após dois anos, a situação se equivalerá a coisa julgada. Caso não haja remessa necessária, estaremos diante de uma decisão equiparada a uma sentença de mérito sem a confirmação pelo tribunal.

Portanto, entendemos que em prestígio ao princípio da supremacia do interesse público, à tutela do direito indisponível, aliado ao fato de que há um microssistema formado pelos dispositivos que tratam da técnica monitória e da estabilização da tutela antecipada, tal como defendido por parte da doutrina, haveria de se concluir pela remessa necessária como condição também para a estabilização, o que esvaziaria o principal efeito monitório, pelo que, em nosso sentir, restaria inviável, ou melhor dizendo, sem qualquer efeito prático, a técnica da estabilização da tutela em face do Poder Público.

${ }^{176}$ CUNHA, J. L. C. da., op. cit., p. 315. 


\section{Tutela de evidência contra a Fazenda Pública}

É possível a tutela de evidência em face da Fazenda Pública.

No tocante à hipótese preconizada no inciso I do artigo 311 do CPC, poderá ser concedida tutela provisória em desfavor da Fazenda pública se esta vier a agir com abuso do direito de defesa.

Também será possível a concessão da tutela de evidência em face da Fazenda Pública na hipótese prevista no inciso II do 311 do CPC.

Nessas situações, o juiz pode, liminarmente inclusive, conceder a tutela de evidência, independentemente de haver demonstração de perigo de dano ou de risco à inutilidade do resultado final do processo, pois a pretensão da parte aparenta ser indiscutível, não sendo seriamente contestável. Assim, somente não será concedida a tutela de evidência se a situação do autor não se ajustar à ratio decidendi do precedente obrigatório, seja por haver a necessidade de ser feita uma distinção no caso, em razão de alguma peculiaridade que o diferencie do precedente obrigatório, seja pela necessidade de revisão do precedente, por razões de superação, uma vez que os institutos da superação e da distinção tem por escopo evitar a fossilização do direito, ou como bem colocado pelo Ministro Luiz $\mathrm{Fuz}^{177}$, servem como antídoto ao engessamento do pensamento jurídico, uma vez que tal como o direito positivo, a jurisprudência encontra-se em permanente mutação e, desse modo, reclama a existência de instrumentos que permitam a aplicação congruente das normas e valores vigentes.

Convém ressaltar que o enunciado 35 do Fórum Permanente de Processualistas Civis assim estabelece: “As vedações à concessão da tutela antecipada contra a Fazenda Pública não se aplicam aos casos de tutela de evidência". ${ }^{178}$

Todavia, entendemos que tal enunciado deve ser interpretado no sentido de que tais vedações legais aplicam-se na hipótese do inciso IV do 311 do CPC.

\footnotetext{
177 BRASIL. Jurisprudência. STF- ADI 4060, Rel. Min. LUIZ FUX, Tribunal Pleno, julgado em 25/02/205, publicado no DJe de 04/05/2015.

${ }^{178}$ PEIXOTO, R. (Coord.) op. cit., 2018.
} 
Dessa forma, podemos afirmar que a decisão concessiva de tutela antecipada que se apoie em entendimento já consolidado no STF não sofre incidência no artigo $1^{\circ}$ da lei $9494 / 97$, posto que poderá haver determinação à Fazenda Pública de pagamento imediato de vantagens a servidores. Esse é o entendimento plasmado em diversos precedentes do STF.

Já na hipótese do inciso III do artigo 311 do CPC, não é comum a existência de ação de depósito contra a Fazenda Pública, porém se for ajuizada uma ação de depósito contra a Fazenda Pública, cabe a tutela provisória de evidência com fulcro no mencionado dispositivo legal.

Por sua vez, a hipótese preconizada no inciso IV do artigo 311 do CPC trata da situação em que havendo evidência documental numa ação de procedimento comum contra a Fazenda Pública, em que não haja dúvida razoável oposta ao documento, é possível ao juiz conceder a tutela de evidência para afastar o efeito suspensivo da apelação, desde que não incidam no caso, as hipóteses legais de vedação de tutela provisória.

É preciso interpretar esse inciso IV do 311 conjuntamente com o artigo 1059 do CPC, pois o juiz pode conceder a tutela de evidência contra a Fazenda Pública, desde que isso não implique pagamento ou expedição de precatório ou de requisição de pequeno valor. 


\section{Conclusão}

Dividiu-se o trabalho, didaticamente, em duas partes. Na primeira parte, procuramos demonstrar as importantes inovações trazidas pelo novo Código de Processo Civil no campo da tutela provisória se comparado à sistemática preconizada no Código de Processo Civil de 1973.

Em relação à tutela de urgência, houve um enorme avanço ao se reconhecer, expressamente no novo Código de Processo Civil, que a tutela antecipada e a tutelar cautelar são espécies do mesmo gênero e, por essa razão, com disposições gerais aplicadas a ambas. Podemos dizer que o legislador quase chegou a um único regime jurídico aplicável às tutelas de urgências, pecando tão somente ao estabelecer procedimentos distintos para a tutela cautelar e tutela antecipada antecedentes.

Em linhas gerais, pode-se dizer que as tutelas provisórias foram trazidas pelo $\mathrm{CPC} / 15$ como técnicas processuais destinadas a abreviar a tramitação processual, possibilitando no caso da cautelar, a adoção de medidas relacionadas à prevenção ou obstaculização de danos passíveis de afetarem o resultado do processo relacionado diretamente ao pedido principal.

Nesse contexto, a existência dos requisitos da probabilidade do direito e o perigo de dano ou risco ao resultado útil do processo se destacam como pressupostos para a concessão da tutela cautelar (antecedente ou incidental), submetendo-se ao crivo do julgador, para o exercício do poder geral de cautela do juiz.

Outrossim, ressaltamos ao longo de nosso trabalho que na nova codificação, houve a extinção do processo cautelar autônomo, tendo sido ele transformado numa técnica processual passível de ser manejada inicialmente ou no bojo de uma ação já ajuizada.

Assim, as modificações levadas a efeito pelo novo CPC conduziram à extinção dos procedimentos específicos para a concessão das anteriormente denominadas medidas cautelares nominadas. Dessa forma, o legislador prestigiou a atuação do juiz no contexto da tutela provisória por intermédio da ampliação de 
seu poder geral de cautela, estabelecendo requisitos genéricos para a aferição da possibilidade ou não de sua concessão. Em virtude da ausência de procedimentos específicos para requerimento de diferentes medidas cautelares, o julgador, diante de um caso concreto, irá avaliar qual a medida mais efetiva a ser aplicada, de modo a prestigiar a efetividade do provimento cautelar, minimizando, por conseguinte, os danos às partes, acarretando maior segurança jurídica, uma vez que excessivas formalidades para o requerimento das medidas cautelares, acabam por dificultar o acesso à justiça.

Diante de tantas alterações, entendemos que essa previsão de um regramento geral para a tutela provisória, com requisitos dotados de generalidade, permite ao julgador utilizar expedientes processuais que facilitam a preservação do objeto do processo, bem como evita o seu respectivo perecimento.

No tocante à tutela de evidência, o legislador processual ampliou as possibilidades para a sua concessão, as quais se bem utilizadas, poderão contribuir sobremaneira para a efetividade do processo, em especial por meio das novas hipóteses preconizadas pelo novo Código de Processo Civil, as quais estão previstas nos incisos II e IV do artigo 311, isto é, naqueles processos em que se discutem questões já pacificadas pela jurisprudência, bem como, quando estivermos diante de prova documental suficiente dos fatos constitutivos do direito do autor e o réu não opuser prova capaz de gerar dúvida razoável. Conforme esclarecemos, o novo Código atento ao enorme agigantamento na quantidade de litígios, causados em razão de alguns fatores tais como, ampliação dos meios de comunicação, aumento da consciência jurídica dos cidadãos, desenvolvimento desenfreado de novas tecnologias, dentre outros, adota uma técnica de solução, com força no precedente obrigatório que tem por escopo conferir tratamento adequado e racional às questões repetitivas.

Outrossim, demonstramos as inovações trazidas pelo novo Código ao preconizar a técnica da estabilização da tutela antecipada, que também poderá servir como importante instrumento para concretizar a direito de ação, em consonância com a efetividade da tutela jurisdicional, uma vez que cristaliza situações que se resolvem com a execução da tutela antecipada, tornando despiciendo o prosseguimento do processo.

Nesse passo, concluiu-se que a previsão de estabilização da tutela antecipada antecedente está em harmonia com os objetivos centrais do CPC/15, 
contribuindo para contenção da litigiosidade e representando mais um passo evolutivo na quebra do dogma da cognição plena.

Devemos salientar, no entanto, que o advento do $\mathrm{CPC} / 15$, por si só, não traz soluções imediatas e definitivas para todos os problemas de nosso sistema jurídico, notadamente para o excesso de litigiosidade e morosidade do Poder Judiciário. No entanto, pelas significativas alterações e até mesmo pela mudança de paradigma empreendida pela nova codificação, em nosso sentir, seus objetivos contribuem sobremaneira para a concretização de uma justiça mais célere e mais efetiva.

Na segunda parte do trabalho, identificou-se, inicialmente, a abrangência da expressão "Fazenda Pública", concluindo-se que a expressão restringe- se às pessoas jurídicas de direito público, abrangendo a União, Estados, Municípios e Distrito Federal, com suas respectivas autarquias e fundações públicas. Outrossim, explicitamos que apesar de não estarem abrangidas pela expressão Fazenda Pública, as estatais prestadoras de serviços públicos gozam das prerrogativas processuais inerentes ao Poder Público, conforme entendimento sedimentado no âmbito do STF.

Demais disso, analisou-se o instituto da tutela provisória e a sua compatibilização com o regime especial conferido à Fazenda Pública, concluindo que das grandes e importantes inovações introduzidas no ordenamento jurídico pátrio pelo novo Código de Processo Civil, não existem ainda respostas satisfatórias acerca do tema, o que demandará amplos debates a fim de amoldar os novos institutos.

Analisamos as diversas vedações legais acerca da concessão de providências liminares em face do Poder Público e o entendimento jurisprudencial no sentido de sua constitucionalidade, porém no sentido de dar interpretação restritiva a essas restrições legais.

Entendemos que a superveniência do Novo Código de Processo Civil não deve alterar o panorama jurisprudencial acerca da constitucionalidade das normas restritivas, visto que o artigo 1059 do $\mathrm{CPC} / 15$ vem no mesmo sentido das normas anteriores a ele.

Outrossim, buscou-se investigar acerca da possibilidade de estabilização da decisão que concede a tutela antecipada em caráter antecedente contra a Fazenda Pública, tendo por fundamento as novas previsões contidas nos artigos 303 e 304 
do Código de Processo Civil de 2015 (CPC/15 - Lei n. 13.105/15). Analisou-se, especificamente, se a estabilização da tutela de urgência guarda compatibilidade com as prerrogativas materiais e processuais conferidas ao Poder Público, e concluímos pela sua incompatibilidade, uma vez que a Fazenda Pública não fica sujeita ao efeito material da revelia, considerando que este não incide quando estiverem em jogo direitos indisponíveis, nos termos do artigo 345, II do CPC. Ademais, através de uma interpretação extensiva do artigo $701 \S 4^{\circ}$ do $\mathrm{CPC}$, que preconiza o cabimento de reexame necessário em face da sentença que decide a ação monitória, considerando que a estabilização da tutela antecedente também é uma espécie de tutela monitória, o pronunciamento que extingue o processo nesse caso, por se tratar de sentença, deve ser objeto de reexame necessário, apesar de não ter decidido definitivamente o mérito. Portanto, pelas razões expostas, entendemos que em prestígio ao princípio da supremacia do interesse público, à tutela do direito indisponível, aliado ao fato de que há um microssistema formado pelos dispositivos que tratam da técnica monitória e da estabilização da tutela antecipada, restaria inviável, a técnica da estabilização da tutela em face do Poder Público.

Por fim, analisamos o cabimento da tutela provisória de evidência contra a Fazenda Pública, mencionando inclusive, o teor do enunciado 35 do Fórum Permanente De Processualistas Civis que preconiza que as vedações à concessão da tutela antecipada contra a Fazenda Pública não se aplicam aos casos de tutela de evidência. Em relação a esse ponto, concluímos que esse enunciado deve ser interpretado no sentido de que tais vedações legais se aplicam na hipótese do inciso IV do 311 do CPC. 


\section{Referências Bibliográficas}

ABREU, Rafael Sirangelo de. Igualdade e processo: posições processuais equilibradas e unidade do direito. São Paulo: Revista dos Tribunais, 2015.

ALVIM, Eduardo Arruda (Coord). As leis impeditivas de liminar realmente impedem? O novo mandado de segurança: estudos sobre a Lei 12.016/09. Belo Horizonte: Fórum, 2010, p. 159-168.

ANDRADE, Érico; NUNES, Dierle. Os contornos da estabilização da tutela provisória de urgência antecipatória no novo CPC e o "mistério" da ausência de formação da coisa julgada. 2015. Disponível em: <http://www.tjmg.jus.br/ data/files/D9/E6/05/4D/8D17D410B7C917D40D4E08A8/Tutel a_Provisoria_ e_ estabilizacao.pdf>. Acesso em: 28 dez. 2018.

ARENHART, Sérgio Cruz. A tutela inibitória da vida privada. São Paulo: RT, 2000.

ÁVILA, Humberto. Repensando a supremacia do interesse público sobre o particular. In: SARMENTO, Daniel (Org) Interesses públicos versus interesses privados: desconstruindo o princípio da supremacia do interesse público. 3. tir. Rio de Janeiro: Lumen Juris, 2010.

BARROSO, Luís Roberto. Curso de Direito Constitucional contemporâneo: os conceitos fundamentais e a construção de um novo modelo. 2. ed. São Paulo: Saraiva, 2010.

BEDAQUE, José Roberto dos Santos. Tutela cautelar e tutela antecipada: tutelas sumárias e de urgência (tentativa de sistematização). 3. ed. São Paulo: Malheiros, 2003.

Tutela cautelar e tutela antecipada: tutelas sumárias e de urgência. 4 . ed. São Paulo: Malheiros, 2006.

BINENBOJM, Gustavo. Da supremacia do interesse público ao dever de proporcionalidade: um novo paradigma para o direito administrativo. In: SARMENTO. Daniel (Org) Interesses públicos versus interesses privados: desconstruindo a supremacia do interesse público. Rio de Janeiro: Lumen Juris, 2005..

BRASIL. Constituição da República Federativa do Brasil de 1988. Art. $5^{\circ}$. Disponível em: < www.senado.leg.br/atividade/const/con1988/ con1988_ 15. 12. 2016/art_5_.asp>. Acesso em: 10 nov. 2018. 
Jurisprudência. Acórdão unânime da Terceira Turma do STJ, REsp. 1178500/SP. rel. Min. Nancy Andrighi, j. 04/12/2012. DJe 18/12/2012.

Acórdão unânime da quinta Turma do STJ, AgRg no REsp 1120170/RS, Rel. Min Jorge Mussi, j. 03/11/2009.

Acórdão unânime da Quinta Turma do STJ, AgRg no Ag 1161985/ES, Rel. Min Arnaldo Esteve. J. 22/06/2010 DJU 02/08/2010.

Acórdão não unânime da Primeira Turma do STJ. REsp. 1.319.769/GO, rel. Min. Sérgio Kukina, rel. p/ acórdão Min. Benedito Gonçalves, j. 20.8.2013, DJe 20.9.2013.

Acórdão unânime da Segunda Turma do STJ. REsp. 1.309.137/MG, rel. Min. Herman Benjamin, j. 8.5.2012, DJe22.5.2012.

Supremo Tribunal Federal. Ação Declaratória de Constitucionalidade $\mathbf{n}^{\mathbf{0}}$ 4. Requerentes: Presidente da República, Mesa do Senado Federal e Mesa da Câmara dos Deputados. Relator: Min. SYDNEY SANCHES, Relator p/ Acórdão: Min. Celso de Mello. Dj, 15 out. 2008. Disponível em: <http://www.stf.jus.br/portal/ jurisprudencia/ listarJurisprudencia . asp?s1=\%28ADC $\% 24 \% 2 \mathrm{ESCLA} \% 2 \mathrm{E}+\mathrm{E}+4 \% 2 \mathrm{ENUME} \% \quad 2 \mathrm{E} \% 29+\mathrm{OU}+\% \quad 28$ ADC\%2EACMS \% 2 E+ADJ2+4\%2EACMS\%2E\%29\&base= base Acordaos \& url $=>$. Acesso em: 24 nov. 2018.

Lei n. 12.016 de 07 de agosto de 2009. Planalto. Disponível em: < http://www.planalto.gov.br/ccivil_03/_ato2007-2010/2009/lei/112016.htm>.

Acesso em: 10 dez. 2018.

Lei n. 13.105 de 16 de março de 2015. Planalto. Disponível em: < https://www.planalto.gov.br/ccivil_03/_ato2015-2018/2015/lei/113105.htm>. Acesso em: 5 dez. 2018.

Lei n. 2.770 de 04 de maio de 1956. Planalto. Disponível em: < https://www.planalto.gov.br/ccivil_03/leis/1950-1969/12770.htm>. Acesso em: 18 nov. 2018.

Lei n. 4.348 de 26 de junho de 1964. Planalto. Disponível em: < http://www.planalto.gov.br/ccivil_03/Leis/L4348.htm>. Acesso em: 18 nov. 2018.

Lei n. 5.021 de 09 de junho de 1966. Planalto. Disponível em: < http://www.planalto.gov.br/ccivil_03/leis/L5021.htm>. Acesso em: 19 nov. 2018.

Lei n. 8.437 de 30 de junho de 1992. Planalto. Disponível em: <https://www.planalto.gov.br/ccivil_03/leis/L8437.htm>. Acesso em: 23 nov. 2018.

Lei n. 9.494 de 10 de setembro de 1997. Planalto. Disponível em: < http://www.planalto.gov.br/ccivil_03/leis/L9494.htm>. Acesso em: 10 dez. 2018. 
Lei $\mathbf{n}^{\mathbf{5}}$ 5.869, de 11 de janeiro de 1973. Código de processo civil. Disponível em: <http://www.planalto.gov.br/ccivil_03/LEIS/L5869.htm>. Acesso em: 10 nov. 2018.

Lei no 8.952, de 13 de dezembro de 1994. Disponível em: < https:// presrepublica.jusbrasil.com.br/legislacao/103436/lei-8952-9 >. Acesso em: 5 dez. 2018.

. Lei $\mathrm{n}^{\circ} \mathbf{2 . 7 7 0}$, de 4 de maio de 1956. Disponível em: < www.planalto.gov.br/ ccivil_03 /LEIS/1950-1969/L2770.htm >. Acesso em: 10 dez. 2018.

- Súmula 212. Supremo Tribunal de Justiça. Disponível em: < https://ww2.stj.jus.br/docs.../stj-revista-sumulas-2010_15_capSumula212 alterada .pdf >. Acesso em: $10 \mathrm{dez} .2018$.

BUENO, Cassio Scarpinella. Tutela antecipada e ações contra o Poder Público (Reflexões quanto a seu conhecimento como consequência da necessidade de efetividade do processo). In: WAMBIER, Teresa Arruda Alvim. (Coord.). Aspectos polêmicos da antecipação de tutela. São Paulo: Editora Revista dos Tribunais, 1997.

A Nova Lei do Mandado do Segurança. São Paulo: Saraiva, 2009.

Curso sistematizado de direito processual civil: tutela antecipada, tutela cautelar e procedimentos cautelares específicos. 4. ed. rev. e atual. São Paulo: Saraiva, 2009, v. 4.

CALAMANDREI, Piero. Introdução ao estudo sistemático dos procedimentos cautelares. Trad. Carla Roberta Andreasi Bassi- trad. ed. italiana de 1936. Campinas: Servanda, 2000.

CÂMARA, Alexandre Freitas. O novo processo civil brasileiro. São Paulo: Atlas, 2016.

CARVALHO FILHO, José dos Santos. Manual de direito administrativo. 25. ed. São Paulo: Atlas, 2012.

CASTRO, Luís Otávio Sequeira de. Comentários à Nova Lei do Mandado de Segurança (em coautoria com Luiz Manoel Gomes Junior, Luana pedrosa de Figueiredo Cruz, Rogério Favreto e Sidney Palharini Júnior). São Paulo: Revista dos Tribunais, 2009.

CAVALCANTI, Francisco. O novo regime jurídico do mandado de segurança. São Paulo: MP, 2009, n. 5.31, p. 114-115.

COSTA, Eduardo José da Fonseca. Comentários ao art. 304. In: STRECK, Lênio Luiz; NUNES, Dierle; CUNHA, Leonardo. (Orgs.). Comentários ao Código de Processo Civil. São Paulo: Saraiva, 2016.

- (Orgs.). Coleção grandes temas do novo CPC: tutela provisória.

Salvador: JusPodivm, 2016. 
CUNHA, Leonardo José Carneiro da. A Fazenda Pública em juízo. 13. ed. São Paulo: Forense, 2016. 11. ed. São Paulo: Dialética., 2010.

- Tutela Jurisdicional de Urgência-Relatório Nacional (Brasil). Texto preparado para o Congresso Argentina-Brasil de direito processual. São Paulo. Dez 2012.

DIDIER JR., Fredie. Fundamentos do princípio da cooperação no direito processual civil português. Coimbra: Coimbra Editora, 2010.

Curso de Direito Processual Civil. 11. ed. Salvador: JusPodivm, 2016. v. 2.

; BRAGA, Paula Sarno; OLIVEIRA, Rafael Alexandria de. Curso de Direito Processual Civil. 10. ed. Salvador: JusPodivm, 2015. v. 2.

2016. v. 3 . . Curso de Direito Processual Civil. 13. ed. Salvador: JusPodivm,

Direito ao silêncio no processo civil brasileiro (arts. 347, CPC e 229, CC). Disponível em: <http://www.frediedidier.com.br/ wpcontent / uploads/ 2008 /03/direitoaosilencionoprocessocivilbrasileiro.pdf>. Acesso em: 20 nov. 2018.

DINAMARCO, Cândido Rangel. A reforma do código de processo civil. 3. ed. São Paulo: Malheiros, 1996. 2000, t. 1.

Fundamentos do processo civil moderno. 3. ed. São Paulo: Malheiros, Instrumentalidade do Processo. São Paulo: Malheiros, 2002.

Nova era do processo civil. São Paulo: Malheiros, 2003.

DWORKIN, Ronald. Levando o direito a sério. Trad. Nelson Boeira. São Paulo: Martins Fontes, 2002.

FÓRUM PERMANENTE DE PROCESSUALISTAS CIVIS, Carta de São Paulo, São Paulo, 2016. Disponível em: <http://portalprocessual.com/wpcontent/uploads/ 2016/05/Carta-de-S\%C3\%A3o-Paulo.pdf>. Acesso em: 18 dez. 2018.

FUX, Luiz. Curso de direito processual civil. 3. ed. Rio de Janeiro: Forense, 2001 .

Tutela de segurança e Tutela de evidência. São Paulo: Saraiva, 1996. (fundamentos da tutela antecipada)

GAJARDONI, Fernando da Fonseca. Flexibilização procedimental: um novo enfoque para o estudo do procedimento em matéria processual, de acordo com as recentes reformas do $C P C$. São Paulo: Atlas, 2008. In:__. Reflexos do tempo no direito processual civil, Revista de Processo, v. 153, nov. 2007. 
GIANESINI, Rita. Descabimento da Tutela antecipada e da execução provisória contra a Fazenda Pública. In: SUNDFELD, Carlos Ari; BUENO, Cassio Scarpinella. Direito processual Público: A Fazenda em juízo. São Paulo: Malheiros, 2003.

GRECO, Leonardo. O princípio do contraditório. In: Estudos de direito processual. Campos dos Goytacazes: Ed. Faculdade de Direito de Campos, 2005.

A tutela de urgência e de evidência no Código de Processo Civil de 2014/2015. Revista Eletrônica de Direito Processual - REDP.

GRINOVER, Ada Pellegrini. Da ação monitória em face da Fazenda Pública. Consulex, Rio de Janeiro, ano 1, n. 6, [20__?].

Tutela jurisdicional diferenciada: a antecipação e sua estabilização. Revista de Processo, São Paulo, a. 30, v. 121, 2005.

HOFFMAN, Paulo. Razoável duração do processo. São Paulo: Quartier Latin, 2006.

JORGE, Flávio Cheim. Teoria Geral dos Recursos Cíveis. 5. ed. São Paulo: Revista dos Tribunais, 2012.

JUSTEN FILHO, Marçal. O direito das agências reguladoras independentes. São Paulo: Dialética, 2002.

LAMY. Eduardo de Avelar. Flexibilização da tutela de urgência. 2. Ed. Curitiba: Juruá, 2007.

LOPES, João Batista. Tutela Antecipada no Processo Civil Brasileiro. 2. ed. São Paulo: Saraiva, 2003.

Efetividade da tutela jurisdicional à luz da constitucionalização do processo civil. Revista de Processo. Vol. 116. p. 31-32 São Paulo: RT, jul-ago 2004.

MACÊDO, Lucas Burril de. Antecipação de tutela por evidência e os precedentes obrigatórios. Revista de Processo. São Paulo: Revista dos Tribunais. v. 242, abr. 2015.

MARINONI. Luiz Guilherme. Antecipação de Tutela. 10. ed. São Paulo: Revista dos Tribunais, 2008.

; ARENHART, Sérgio Cruz. Novo curso de processo civil: tutela dos direitos mediante procedimentos diferenciados. São Paulo: Revista dos Tribunais, 2015. v. 3.

; MITIDIERO, Daniel. Código de Processo Civil Comentado. 2. ed. São Paulo: Editora Revista dos Tribunais, 2016.

MARINONI, Luiz Guilherme. Estabilização da tutela. [S.1.]. Revista de processo, v. 279, p. 225-243, maio, 2018. 
MEDAUAR, Odete. Direito administrativo em evolução. São Paulo: Malheiros. 2003.

MEIRELLES, Hely Lopes. Direito administrativo brasileiro. 23. ed. atual. por Eurico de Andrade Azevedo, Délcio Balestero Aleixo e José Emmanuel Burle Filho. São Paulo: Malheiros, 1998.

Direito Administrativo Brasileiro. 32. ed. São Paulo: Malheiros, 2006.

MELlO, Celso Antônio Bandeira de. Conteúdo Jurídico do princípio da igualdade. 3. ed. São Paulo: Malheiros, 2002.

Curso de Direito Administrativo. 22. ed. São Paulo: Malheiros, 2007. . 5. ed. , 1994.

MEDINA, José Miguel Garcia; ARAÚJO, Fábio Caldas de; GAJARDONI, Fernando da Fonseca. Procedimentos cautelares e especiais: ações coletivas, ações constitucionais, jurisdição voluntária, antecipação dos efeitos da tutela, Juizados Especiais Cíveis, Federais e da Fazenda Pública. [S.l: s.n.], 2010.

MENDONÇA JR, Delosmar. Princípios da ampla defesa e da efetividade no processo civil brasileiro. São Paulo: Malheiros, 2001.

MIRANDA, Pontes de. Comentários ao Código de Processo Civil. Rio de Janeiro: Forense, 1996. Tomo III.

MITIDIERO, Daniel. Autonomização e estabilização da antecipação de tutela no novo código de processo civil. Revista Magister de Direito Civil e Processual Civil, n. 63, nov./dez. 2014.

MORAES, Jose Roberto de. Prerrogativas processuais da Fazenda Pública. In. SUNDFELD, Carolos Ari; BUENO, Cassio Scarpinella. Direito Processual Público: A Fazenda Pública em juízo. São Paulo: Malheiros 2000.

MOREIRA NETO, Diogo de Figueiredo. Curso de direito administrativo. 16. ed. Rio de Janeiro: Forense, 2014.

MOREIRA, José Carlos Barbosa. Antecipação de tutela: algumas questões controvertidas. Temas de direito Processual- Oitava série. São Paulo: Saraiva, 2004.

NOGUEIRA JÚNIOR, Alberto. Medidas Cautelares Inominadas Satisfativas ou Justiça Cautelar. São Paulo: LRT. 1999.

NUNES, Dierle; ANDRADE, Érico. Os contornos da estabilização da tutela provisória de urgência antecipatória no novo CPC e o mistério da ausência de formação da coisa julgada. MACÊDO, Lucas Buril de; PEIXOTO, Ravi; FREIRE, Alexandre (Coords.). Doutrina Selecionada: Procedimentos Especiais, Tutela Provisória e Direito Transitório. 2. ed. Salvador: Juspodivm, 2015, v. 4. 
OLIVEIRA, Rafael Carvalho Rezende. Curso de direito Administrativo. 5. ed. Método, 2017.

PEIXOTO, Ravi. (Coord.) Enunciados do Fórum Permanente de Processualistas civis - EFPPC - Comentados. 1. ed. Salvador: JusPodivm, 2018.

PEREIRA, Alex Costa. Tutela Sumária - A estabilização da tutela antecipada e sua adequação ao modelo constitucional do processo civil brasileiro. 2012. Tese (Doutorado em Direito). Programa de Pós-Graduação em Direito, Faculdade de Direito, Universidade de São Paulo, São Paulo, 2012. Disponível em: <http://www.teses.usp.br/teses/disponiveis/2/2137/tde-26032013103821/ publico/ ALEX_COSTA_PEREIRA_Resumo.pdf>. Acesso em: 7 jan. 2019.

PEREIRA, Hélio do Valle. O novo mandado de segurança: comentários à Lei 12016, de 7/08/2009. Florianópolis: Conceito Editorial, 2010.

PISIANI, Andrea Proto. Lezioni di Diritto Processuale Civile. Napoli: Jovene Editore, 1999.

PRADO, Ana Paula Sanzovo de Almeida. Pode haver estabilidade de tutela satisfativa antecedente contra a Fazenda Pública? Publicações da Escola AGU. Disponível em: < https://seer.agu.gov.br/index.php/EAGU/article/view/22 92>. Acesso em: 26 dez. 2018.

REDONDO, Bruno Garcia. Estabilização, modificação e negociação da tutela de urgência antecipada antecedente: principais controvérsias. In: COSTA, Eduardo José da Fonseca; DIDIER JR., Fredie; GOUVEIA FILHO, Roberto P. Campos; PEREIRA, Mateus Costa. (Orgs.). Coleção grandes temas do novo CPC: tutela provisória. Salvador: JusPodivm, 2016. v. 6.

Estabilização, modificação e negociação da tutela de urgência antecipada antecedente: principais controvérsias. Revista de Processo, v. 244, junho, 2015.

RIBEIRO, Leonardo Ferres da Silva. Tutela provisória. In: TALAMINI, Eduardo; WAMBIER, Teresa Arruda Alvim. (Orgs.). Temas essenciais do novo CPC: Análise das principais alterações do sistema processual civil brasileiro. São Paulo: Revista dos Tribunais, 2016.

Tutela provisória: tutela de urgência e tutela da evidência. Do CPC/1973 ao CPC/2015. In: TALAMINI, Eduardo; WAMBIER, Teresa Arruda Alvim. (Orgs.). Coleção Liebman. São Paulo: Editora Revista dos Tribunais, 2015.

A "prova" exigida para a concessão da tutela de urgência: $a$ demonstração, no plano processual, dos requisitos autorizadores para a concessão da tutela cautelar e da antecipação de tutela. Disponível em: <http: //www.silvaribeiro.com.br/ artigos/artigo3.pdf>. Acesso em: 26 dez. 2018.

RODRIGUES, Marco Antônio. Processo civil ambiental. São Paulo: Editora Revista dos Tribunais, 2008.

Suspensão de Segurança: Sustação da eficácia de decisão judicial proferida contra o Poder Público. São Paulo: Revista dos Tribunais, 2000. 
2016.

A Fazenda Pública no Direito Processual Civil. 2. ed. São Paulo: Atlas,

RODRIGUES, Marcelo Abelha. Manual de direito processual civil. 5. ed. São Paulo: Revista dos Tribunais, 2010.

6. ed. São Paulo: Forense, 2016.

SARLET, Ingo Wolfgang. A eficácia dos direitos fundamentais. 3. ed. Porto Alegra: Livraria do advogado, 2003.

SHIER, Paulo Ricardo. Filtragem constitucional. Construindo uma nova dogmática jurídica. Porto Alegre: Sergio Antonio Fabris, 1999.

SICA, Heitor Vitor Mendonça. Doze problemas e onze soluções quanto à chamada "estabilização" da tutela antecipada. In: COSTA, Eduardo José da Fonseca; DIDIER JR., Fredie; GOUVEIA FILHO, Roberto P. Campos; PEREIRA, Mateus Costa. (Orgs.). Coleção grandes temas do novo CPC: tutela provisória. Salvador: JusPodivm, 2016. v. 6.

SILVA, Ovídio A. Batista da. Teoria Geral do Processo. São Paulo: Revista dos Tribunais, 2002.

SILVA, Ricardo Perlingeiro Mendes da. Execução contra a Fazenda Pública. São Paulo: Malheiros, 1999.

SUNDFELD, Carlos Ari; BUENO, Cassio Scarpinella. Direito processual Público: A Fazenda em juízo. São Paulo: Malheiros, 2003.

TALAMINI, Eduardo. Ainda a estabilização da tutela antecipada. In: Migalhas, correlação entre estabilização da tutela, a ação monitória e a fazenda pública $1 / 04 / 2016$.

Tutela de urgência e Fazenda Pública. Revista de Processo, São Paulo, n. 152, out. 2007.

Tutela de urgência no projeto de novo Código de Processo Civil: a estabilização da demanda urgente e a "monitorização" do processo civil brasileiro. Revista de Processo, São Paulo, v. 209, 2012.

TALAMINI, Eduardo; WAMBIER, Luiz Rodrigues. Curso avançado de processo civil: cognição jurisdicional (processo comum de conhecimento e tutela provisória). 16. ed. São Paulo: Editora Revista dos Tribunais, 2016. v. 2.

THEODORO JR, Humberto. Processo cautelar. 24. Ed. São Paulo: Leud, 2008.

Tutela jurisdicional de urgência-Medidas cautelares e antecipatórias. 2. ed. Rio de Janeiro: América Jurídica, 2001.

WAMBIER, Luiz Rodrigues; TALAMINI, Eduardo. Curso avançado de processo civil: cognição jurisdicional (processo comum de conhecimento e tutela provisória). 16. ed. São Paulo: Revista dos Tribunais, 2016. v. 2. 
WAMBIER, Teresa Arruda Alvim et al. Primeiros Comentários ao Novo Código de Processo Civil: artigo por artigo. 2. ed. rev. atual. e ampl. São Paulo: Revista dos Tribunais, 2016.

WATANABE, Kazuo. Da Cognição no processo civil , 4. ed. São Paulo: Saraiva, 2012.

YARSHELL, Flávio Luiz e Abodo, Helena. As questões não tão evidentes sobre a tutela de evidência. Tutela provisória no novo CPC: dos 20 anos de vigência do artigo 273 do CPC/73 ao CPC/15. Coord. Cassio Scarpinella Bueno et. al. São Paulo: Saraiva, 2015.

ZAVASCKI, Teori Albino. Antecipação de tutela. 5. ed. São Paulo: Saraiva, 2007. 6.ed. São Paulo: Saraiva, 2008. 